\title{
MICROSCOPIA ALIMENTAR DE PRODUTOS INDUSTRIALIZADOS DE FRUTAS, COMERCIALIZADOS EM SUPERMERCADOS DE SÃO PAULO, SP
}

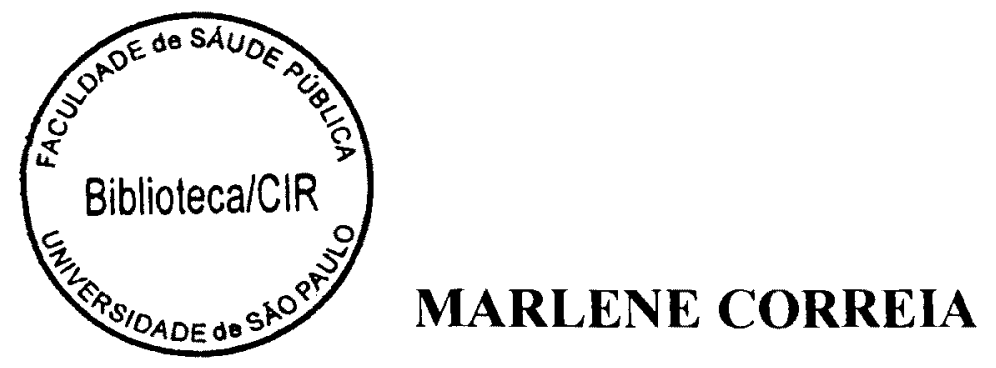

Tese apresentada ao Departamento de Nutrição da Faculdade de Saúde Pública da Universidade de São Paulo para obtenção do Título de Doutor.

Área de concentração: Nutrição

Orientadora:

Prof ${ }^{a}$ Titular MARIA JOSÉ RONCADA

SÃo PAULO 
Dedicatória

In memoriam: Aos meus pais, Mario e Maria, que, com seus exemplos, ensinaram-me a ter confiança e acreditar que é possivel concretizar nossos sonfios.

Aos meus filhos, Marcelo e Alexandre, que, com carinfío, paciência e compreensão, ajudaram-me a chegar ao fim deste trabalho. 


\section{AGRADECIMENTOS}

À minfia Orientadora, Professora Tîtular Maria José Roncada, pela disponibifidade em orientar-me durante todos esses anos, com paciência, segurança e palavras de estímulo, bem como pela grande amizade.

Ao Dr. Odair Zene6on, Diretor da Divisão de Bromatologia e Quimica do Instituto Adolfo Lutz, pela permissão e incentivo para realizar o Curso de Pós-Graduafão.

À Diretora do Serviço de Alimentos do Instituto Adolfo Lutz, Elza Schwarz Gastaldo Badolato, pelo apoio.

À Chefe da Seção de Microscopia Alimentar do Instituto Adolfo Lutz, Regina Maria Moreli Silva Rodrigues, amiga sempre presente, pela força dada para a realizafãa deste trabalfo.

À Márcia Bittar Atui, da Seção de Microscopia Alimentar do Instituto Adolfo Lutz, amiga de todos os momentos, pela amizade e apoio sempre com bom fumor.

Ao Prof. Dr. José Leopoldo Ferreira Antunes, da Faculdade de Odontologia da Universidade de São Paulo, pela onientação no planejamento da amostragem.

Aos funcionários e estagiánios da Seção de Microscopia Alimentar do Instituto Adolfo Lutz, pela cooperação e incentivo.

À Cristina Duran e Letícia Araújo Nagato, da Seção de Bebidas do Instituto Adolfo Lutz, pela colaboração técnica.

Ao Antonio Roberto de Souza Ferreira, da Sefão de Fotomicrografia do Instituto Adolfo Lutz, pela colaboração técnica. 
Aos professores e funcionários do Departamento de $\mathcal{N}$ utrição da Faculdade de Saúde Pública, que direta ou indiretamente contribuíram para a realização deste tra6alho.

À Ângela Maria Pereira Silva Lima, Marilene Rosa da Silva e Silvia Ivone Botelfo, da Sefão de Pós-Graduação, e Maria Aparecida Mendes e Renilda Maria de Figueiredo, do Serviço de Aprimoramento desta Faculdade, pela presteza no atendimento e amizade.

À Maria Lúcia de Faria Ferraz e Maria do Carmo Avamiolano Alvarez, Gibliotecárias desta Faculdade, pela eficiência no atendimento.

À Alderica Barbosa Mearin Luiz e Sara Tetner Burstein, Gibliotecárias do Instituto Adolfo Lutz, pela amizade e colaboração.

À Coordenação de Aperfeiçoamento de Pesoal de $\mathcal{N} i v e l$ Superior - CAPES, pelo apoio financeiro.

À Fundação de Amparo à Pesquisa do Estado de São Paulo - FAPESP, pelo auxífo à pesquisa concedido. 


\section{RESUMO}

Correia M. Microscopia alimentar de produtos industrializados de frutas, comercializados em supermercados de São Paulo, SP. São Paulo; 2000. [Tese de Doutorado - Faculdade de Saúde Pública da USP].

Objetivo. Quantificar filamentos micelianos de fungos e matérias estranhas em geléias de frutas, doces de frutas em pasta e frutas em calda industrializados, utilizando métodos de análise microscópica. Métodos. Foram adotadas as metodologias descritas no Official Methods of Analysis of Association of Official Analytical Chemists International - 1995 (AOAC International), para as análises de contagem de filamentos micelianos pelo método Howard, de filamentos micelianos de Geotrichum e de determinação de matérias estranhas em geléias, doces em pasta e frutas em calda (nesta, a determinação de matérias estranhas utilizou metodologia do Macroanalytical Procedures Manual); quando necessário, os métodos foram adaptados e/ou modificados. Resultados. São comentadas as modificações realizadas nos métodos adotados. Quanto às condições higiênicas dos doces analisados, pelo método Howard verificou-se que o maior percentual de amostras contendo filamentos de fungos foi dos doces em pasta, seguido das geléias e das frutas em calda. Na contagem de filamentos de Geotrichum, o maior percentual de amostras positivas foi encontrado nas frutas em calda, seguido dos doces em pasta e, em menor percentual, das geléias. Para matérias estranhas, as geléias e os doces em pasta apresentaram os maiores percentuais de amostras positivas. As frutas apresentaram comportamento diferente para um mesmo tipo de doce. Conclusão. Os métodos adotados mostraram-se adequados, permitindo leituras satisfatórias tanto de contagem de filamentos de fungos como das matérias estranhas, sendo possivel a sua utilização pelos laboratórios de microscopia de alimentos. Os resultados obtidos nas análises mostram a necessidade de revisão na legislação bromatológica em vigor, com o estabelecimento de limites de tolerância para filamentos micelianos (exceto para Geotrichum) e para fragmentos de insetos, nos produtos de frutas aqui estudados.

Descritores: Produtos de Frutas, Microscopia de Alimentos, Filamentos Micelianos, Método Howard, Geotrichum, Matérias Estranhas 


\section{SUMMARY}

Correia M. Microscopia alimentar de produtos industrializados de frutas, comercializados em supermercados de São Paulo, SP [Food microscopy of processed fruit products, marketed in the supermarkets of São Paulo, SP]. São Paulo (BR); 2000. [Tese de Doutorado - Faculdade de Saúde Pública da Universidade de São Paulo].

Objective. To quantify the mycelial fragments of mold and extraneous materials in fruit jams, in fruit pastes and in canned syrup fruits, making use of food microscopy. Methods. It was used the methodology described in the Official Methods of Analysis of Association of Official Analytical Chemists International - 1995 (AOAC International) to Howard mold counting, to Geotrichum mold counting and to the determination of extraneous materials in jams, fruit pastes and canned syrup fruits (in this determination of extraneous materials it was used the Macroanalytical Procedures Manual methodology); when necessary, the methods were adapted and/or modified. Results. The modifications made in the adopted methods are commented on. In relation to the hygienic conditions of the sweets which were analyzed through the Howard method, it was checked that the biggest percentage of sample containing mycelial fragments of mold was the fruit pastes, followed by the jams and the canned syrup fruits. In the Geotrichum mold counting, the biggest percentage of positive samples was found in the canned syrup fruits, followed by the fruit pastes, and then, in a smaller percentage, the jams. In relation to extraneous materials, the jams and fruit pastes showed the biggest percentage of positive samples. The fruits showed a different procedure to the same kind of sweet. Conclusion. The methods adopted showed to be appropriate, enabling satisfactory reading of the mold counting as well as of the extraneous materials, making their use possible by food microscopy laboratories. The results which were obtained in the analysis show the need of a revision in the food legislation in force, establishing tolerance limits to the mycelial fragments (except for the Geotrichum) and to the insects fragments in the products made of fruit which studied here.

Descriptors: Fruit Products, Food Microscopy, Micelyal Fragments, Howard Mold Counting, Geotrichum Mold Counting, Extraneous Materials 


\section{SUMÁRIO}

1. INTRODUÇÃO

2. REVISÃO DA LITERATURA ……............................................... 3

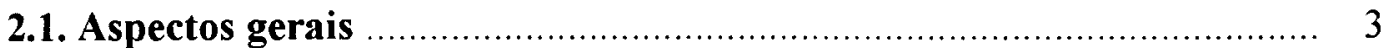

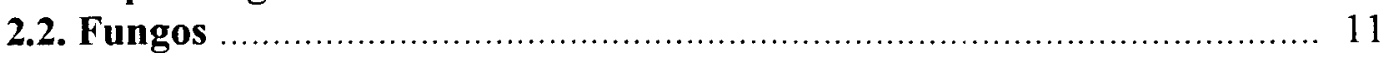

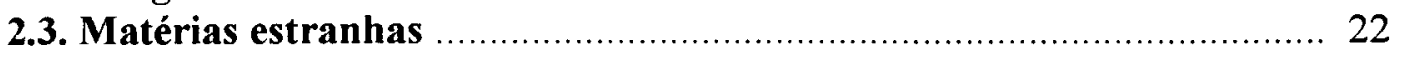

3. OBJETIVOS …

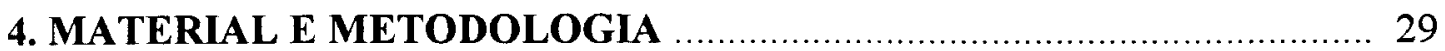

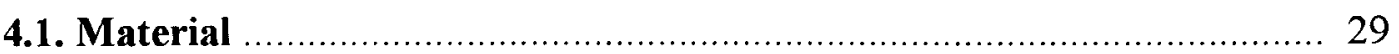

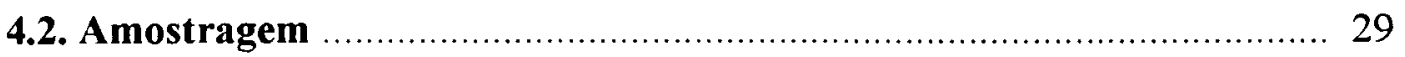

4.2.1. Amostras de geléias de frutas, doces de frutas em pasta e frutas em calda para verificação das condições higiênicas ..................... 30

4.2.2. Amostras-teste de geléias de frutas, doces de frutas em pasta $\mathrm{e}$ frutas em calda para a padronização da metodologia ............................ 31

4.3. Procedimentos analíticos .......................................................... 32

A. Método Howard para contagem de filamentos micelianos ............ 32

4.3.1. Padronização da diluição para as amostras-teste de geléias de frutas e doces de frutas em pasta .................................................. 32

4.3.2. Adaptação do método Howard para frutas em calda .............................. 33

4.3.3. Contagem de filamentos micelianos, pelo método Howard, em geléias de frutas, doces de frutas em pasta e frutas em calda ........... 34

4.3.3.1. Preparo das amostras .............................................................. 34

4.3.3.2. Preparo das câmaras e contagem de filamentos micelianos ................ 34

4.3.3.3. Características morfológicas das hifas de fungos ............................... 35

4.3.3.4. Cálculo do número de filamentos micelianos ................................... 36

B. Método para contagem de filamentos micelianos de Geotrichum ... 36

4.3.4. Adaptação do método de contagem de filamentos micelianos de Geotrichum para frutas em calda ........................................... 36

4.3.5. Contagem de filamentos micelianos de Geotrichum em geléias de frutas, doces de frutas em pasta e frutas em calda ................. 37

4.3.5.1. Preparo das amostras ............................................................ 37

4.3.5.2. Preparo das lâminas para contagem de filamentos micelianos

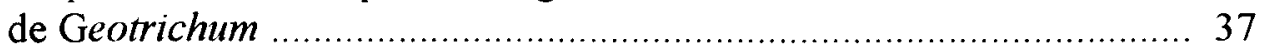

4.3.5.3. Características morfológicas das hifas de Geotrichum ...................... 38

4.3.5.4. Cálculo do número de filamentos de Geotrichum ............................. 38

C. Método para determinação de matérias estranhas ........................ 39

4.3.6. Adaptação de métodos para doces de frutas em pasta e frutas em calda . 39

4.3.7. Determinação de matérias estranhas em geléias de frutas, doces de frutas em pasta e frutas em calda ....................................... 40

4.3.7.1. Isolamento de matérias estranhas ................................................. 40

4.3.7.2. Identificação e contagem de matérias estranhas ................................. 41

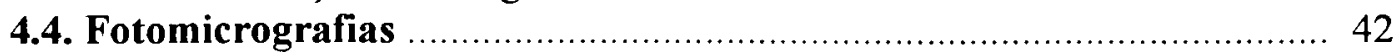

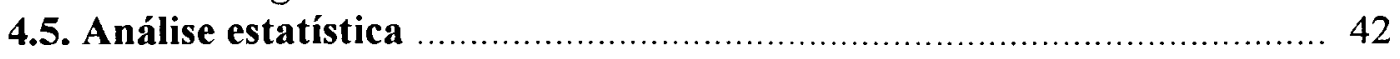

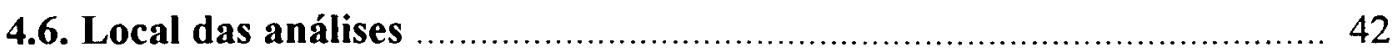


A. Contagem de filamentos micelianos pelo método Howard ............. 43

5.1. Geléias de frutas ........................................................................... 43

5.1.1. Padronização da diluição das amostras-teste para contagem Howard ..... 43

5.1.2. Contagem de filamentos micelianos em geléias de frutas ....................... 44

5.2. Doces de frutas em pasta .......................................................... 49

5.2.1. Padronização da diluição das amostras-teste para contagem Howard ...... 49

5.2.2. Contagem de filamentos micelianos em doces de frutas em pasta ......... 50

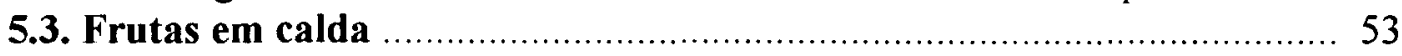

5.3.1. Adaptação do método Howard para frutas em calda .............................. 53

5.3.2. Contagem de filamentos micelianos em frutas em calda ........................ 54

B. Contagem de filamentos micelianos de Geotrichum ........................ 57

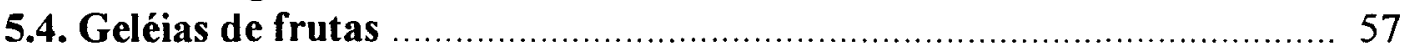

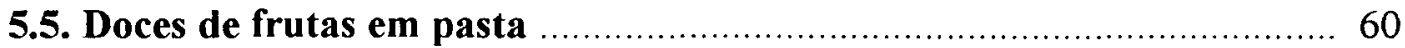

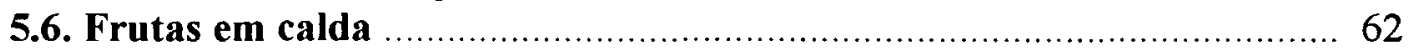

5.6.1. Adaptação do método de contagem de filamentos micelianos de Geotrichum para frutas em calda ................................................ 62

5.6.2. Contagem de filamentos micelianos de Geotrichum em frutas em calda. 63

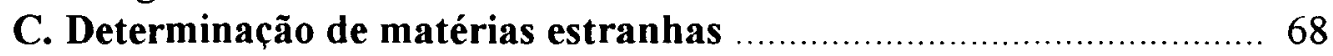

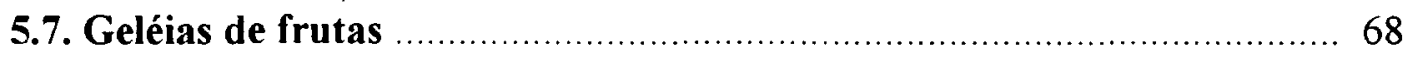

5.8. Doces de frutas em pasta ............................................................... 75

5.8.1. Adaptação de método de determinação de matérias estranhas em doces de frutas em pasta ............................................................ 75

5.8.2. Contagem e identificação de matérias estranhas em doces

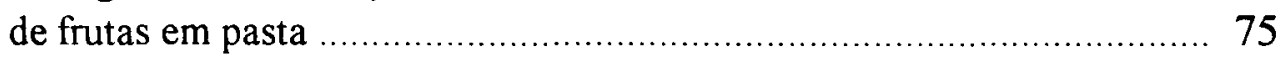

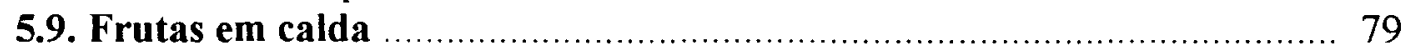

5.9.1. Adaptação de método de determinação de matérias estranhas

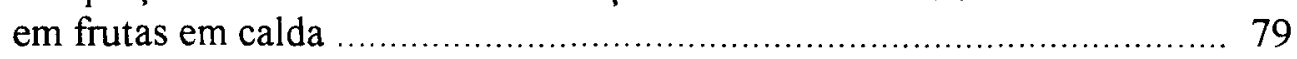

5.9.2. Contagem e identificação de matérias estranhas em frutas em calda ...... 79

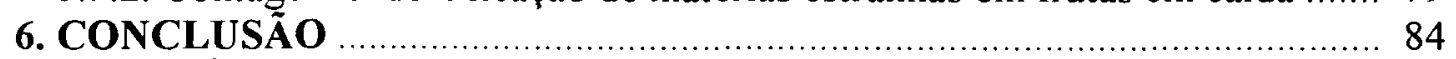

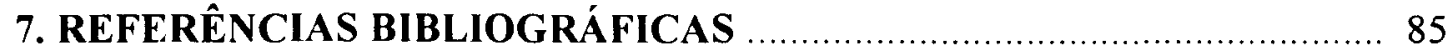

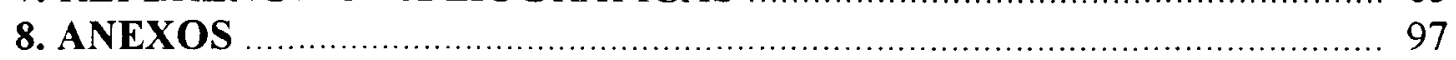




\section{INTRODUÇÃO}

Insetos, ácaros e microrganismos, tais como os fungos, podem, ocasionalmente, causar alterações fisicas e químicas em frutas, em qualquer fase de sua cultura ou de manuseio e transporte, levando a importantes perdas econômicas.

Quando presentes em ambientes industriais, ou mesmo em utensílios e equipamentos desses estabelecimentos, as matérias estranhas (sujidades) podem se integrar aos produtos derivados de frutas, contaminando-os, além de provocar alterações dos caracteres organolépticos e rejeição pelo consumidor.

A detecção dos contaminantes citados, na análise microscópica, permite avaliar as condições higiênicas tanto da matéria-prima utilizada, como do processamento, permitindo, ao consumidor, adquirir produtos que não causem danos à sua saúde, uma vez que os fungos, além de eventualmente causarem alergia, podem contaminar o alimento com micotoxinas; os insetos e ácaros, por sua vez, sendo transportadores de bactérias e vírus, causam doenças, podendo, também, desencadear processos alérgicos.

A legislação de alimentos em vigor exige ausência de sujidades, parasitos e larvas nos produtos de frutas, o que nem sempre é possivel; fragmentos de insetos e matérias estranhas as mais diversas poderão estar presentes, assim como fragmentos de micélio de fungos que, embora inativados pelo processamento térmico, continuam no alimento, indicando utilização de matéria-prima em condições inadequadas.

Embora a Agência Nacional de Vigilância Sanitária do Ministério da Saúde (ANVS/MS) demonstre interesse na atualização da legislação de alimentos, os laboratórios que executam análises bromatológicas pouco podem contribuir oferecendo subsídios aos órgãos governamentais, devido a falta de uniformização da metodologia analítica utilizada para os produtos elaborados com frutas, gerando a escassez de resultados laboratoriais.

Essa situação somente será revertida após a padronização dos métodos e a análise microscópica de produtos de frutas como geléias, doces em pasta e frutas em calda em número representativo, como ocorre em outros países. 
Assim sendo, torna-se imprescindivel a realização de uma pesquisa abrangente, que padronize metodologias analíticas de microscopia alimentar e indique a realidade atual das condições de higiene daqueles produtos.

Dessa forma, este trabalho foi planejado visando não somente avaliar os procedimentos analíticos já existentes e propor outros, tanto para a detecção de filamentos de fungos e de matérias estranhas, como verificar as condições higiênicas de geléias de frutas, doces de frutas em pasta e frutas em calda, todos eles industrializados. 


\section{REVISÃO DA LITERATURA}

\subsection{ASPECTOS GERAIS}

Pelo seu valor nutricional, as frutas desempenham papel importante na saúde humana e sua boa aceitação pela população se deve, além disso, ao seu aroma e sabor.

A grande variedade de frutas disponiveis durante todo o ano, graças ao aprimoramento e desenvolvimento agricolas, faz com que essas e seus produtos derivados tenham grande importância no comércio mundial.

Os principais tipos de frutas (como as cítricas e as maçãs) são cultivados em diferentes regiões da Terra, com a agricultura tradicional tendendo a ser substituída por novas técnicas agricolas, que permitem não só obter cultivares de frutas mais saborosas e mais resistentes ao ataque de pragas, como também um maior rendimento por área plantada (TAYLOR, 1997).

Devido à vasta área territorial e variadas condições climáticas do Brasil, aqui são plantadas tanto fruteiras de clima tropical (abacate, abacaxi, banana, goiaba, os diversos citros, mamão e manga) como de clima temperado (ameixa, figo, caqui, maçã, marmelo, morango, nectarina, pêra, pêssego e uva) (SIMÃO 1971, TOSELLO e col. 1975, JACKIX 1982), com destaque para a produção de laranja, banana e abacaxi (Quadro 1), conforme dados do Instituto Brasileiro de Frutas (IBRAF).

As frutas produzidas no País destinam-se principalmente ao mercado interno, sobretudo para consumo in natura (Quadro 2), além de uma parcela destinar-se à exportação (Quadro 3). 
Quadro 1. Produção brasileira de frutas frescas, em toneladas, no período de 1995/98*.

\begin{tabular}{|lcccc|}
\hline Frutas & $\begin{array}{c}1995 \\
\text { ton }\end{array}$ & $\begin{array}{c}1996 \\
\text { ton }\end{array}$ & $\begin{array}{c}1997 \\
\text { ton }\end{array}$ & $\begin{array}{c}1998 * * * \\
\text { ton }\end{array}$ \\
\hline Abacaxi & 1.330 .983 & 1.466 .527 & 1.686 .381 & 1.470 .098 \\
Banana & 9.939 .625 & 9.833 .830 & 10.418 .530 & 9.219 .097 \\
Goiaba & 255.986 & 260.000 & nd & nd \\
Laranja & 16.361 .999 & 17.994 .220 & 18.957 .058 & 18.826 .759 \\
Limão & 584.528 & 581.200 & nd & nd \\
Mamão & 489.762 & 520.000 & nd & nd \\
Maçã & 686.397 & 653.307 & 773.704 & 773.506 \\
Manga & 820.763 & 890.430 & nd & nd \\
Maracujá & 270.581 & nd & nd & nd \\
Melão & 215.012 & 218.000 & nd & nd \\
Tangerina & 599.323 & 601.080 & nd & nd \\
Uva & 836.545 & 730.805 & 900.979 & 767.470 \\
Coco & $966.677^{* *}$ & $998.120^{* *}$ & $1.015 .359^{* *}$ & $974.023 * *$ \\
Pêssego & $1.498 .668^{* *}$ & $1.630 .000^{* *}$ & $31.510 .700^{* *}$ & $41.539 .700^{* *}$ \\
\hline
\end{tabular}

Fonte: IBRAF (Instituto Brasileiro de Frutas)

ton: toneladas

**: em 1.000 frutos

nd: não disponivel

***: dados preliminares

Quadro 2. Direcionamento da produção de algumas frutas frescas, no mercado interno, em toneladas, em 1996*.

\begin{tabular}{|lrrrrr|}
\hline Frutas & \multicolumn{2}{c}{ Comércio } & & \multicolumn{2}{c|}{ Indústria } \\
\cline { 2 - 3 } \cline { 5 - 6 } & \multicolumn{1}{c}{ ton } & $\%$ & & ton & $\%$ \\
\hline Laranja & 4.678 .494 & 26 & & 13.315 .723 & 74 \\
Manga & 875.430 & 99 & & 11.000 & 1 \\
Maracujá & 53.540 & 15 & & 296.460 & 85 \\
Mamão & 504.400 & 97 & & 15.600 & 3 \\
Goiaba & 147.442 & 57 & & 112.558 & 43 \\
Abacaxi & 1.280 .199 & 79 & & 349.801 & 21 \\
Caqui & 534.798 & 99 & & 5.402 & 1 \\
Banana & 5.085 .670 & 99 & & 40.000 & 1 \\
Melão & 213.640 & 98 & & 4.360 & 2 \\
Maçã & 581.443 & 89 & & 71.900 & 11 \\
Limão e Lima & 492.136 & 85 & & 89.064 & 15 \\
Uva & 321.589 & 44 & & 409.296 & 56 \\
Abacate & 316.500 & 95 & & 16.500 & 5 \\
Tangerina & 590.720 & 98 & & 10.280 & 2 \\
Morango & 34.500 & 53 & & 30.500 & 47 \\
Coco & 627.257 & 62 & 384.448 & 38 \\
\hline
\end{tabular}

Fonte: IBRAF (Instituto Brasileiro de Frutas)

ton: toneladas

* Informação obtida do Banco de Dados - Datafruta, do Instituto Brasileiro de Frutas (IBRAF), em março/1999. 
Quadro 3. Exportações brasileiras de frutas frescas, em toneladas, no período de 1996/98*.

\begin{tabular}{|lrrc|}
\hline Frutas & $\begin{array}{c}\text { 1996 } \\
\text { ton }\end{array}$ & \multicolumn{1}{c}{1997} & \multicolumn{1}{c|}{ ton } \\
\hline Laranja & 99.223 & 91.662 & ton \\
Tangerina & 7.599 & 9.325 & 5.308 \\
Limão e limas & 1.324 & 1.512 & 2.301 \\
Outros citricos & 18 & 8 & nd \\
Melão & 50.719 & 45.729 & 65.004 \\
Uva & 4.516 & 3.705 & 4.405 \\
Maçã & 3.308 & 20.725 & 10.706 \\
Figo & 662 & 679 & nd \\
Abacaxi & 11.542 & 12.956 & 13.002 \\
Goiaba e manga & 24.335 & 23.542 & 99.185 \\
Papaia & 5.693 & 7.869 & 9.879 \\
Abacate & 371 & 260 & 296 \\
Banana & 29.938 & 40.061 & 68.555 \\
Melancia & 7.620 & 5.811 & 8.808 \\
Morango & 181 & 92 & 32 \\
Pêssego & 2 & 18 & nd \\
Nectarina & 7 & 3 & nd \\
Ameixa & 0,4 & 15 & nd \\
Framboesa & 20 & 114 & nd \\
Outras frutas frescas & 123 & 108 & 155 \\
\hline Fon: IBRF & & & \\
\hline
\end{tabular}

Fonte: IBRAF (Instituto Brasileiro de Frutas)

nd: não disponivel ton: toneladas

Como a produção de frutas está sujeita a flutuações devido a vários fatores, como, por exemplo, condições climáticas, e várias delas por serem delicadas são susceptiveis ao esmagamento e consequiente decomposição, exigindo, assim, consumo rápido, a industrialização permite o aproveitamento da colheita pela fabricação, entre outros, de polpas, que serão utilizadas como matéria-prima para elaboração de geléias, doces em pasta, néctares e outros produtos.

Para algumas frutas, a industrialização chega a representar um percentual importante, superior a 50\% como no caso da uva, e maior que o dobro, como acontece com a laranja e o maracujá (Quadro 2).

Embora, como já citado, predomine o consumo de frutas frescas (Quadro 2), a comercialização de produtos de frutas processadas vem aumentando a cada ano. As frutas em calda de pêssego, abacaxi e figo e as polpas de goiaba e manga são os produtos mais consumidos no mercado interno, além das geléias de morango, abacaxi, goiaba, uva e pêssego e os néctares de manga e mamão (AMARO 1997). 
Apesar do processamento de doces em pasta (goiabada, marmelada e bananada) se dar também em grandes indústrias, é realizado, ainda, principalmente, por empresas de pequeno porte, com características artesanais (AMARO 1997).

As frutas cristalizadas (laranja, figo, cidra, mamão e abacaxi) também são produzidas principalmente por pequenos fabricantes, de forma artesanal e em volume insuficiente para atender ao mercado interno; quanto à produção de frutas secas ou dessecadas é praticamente inexistente em escala comercial (BERBARI e col. 1992, AMARO 1997).

Os sucos e as polpas de frutas produzidas destinam-se, também, à exportação e, em alguns casos, como suco de laranja (Quadro 4) e polpas de manga, de banana e de mamão (Quadro 5) a exportação é maior que o consumo no mercado interno.

Quadro 4. Mercado industrial de sucos de frutas (estimativa), em toneladas, no período de 1995/96*.

\begin{tabular}{|c|c|c|c|c|c|c|}
\hline \multirow{2}{*}{$\begin{array}{c}\text { Sucos } \\
\text { de frutas }\end{array}$} & \multicolumn{3}{|c|}{1995} & \multicolumn{3}{|c|}{1996} \\
\hline & $\begin{array}{c}\text { Produção } \\
\text { ton }\end{array}$ & $\begin{array}{c}\text { Mercado } \\
\text { interno } \\
\text { ton }\end{array}$ & $\begin{array}{c}\text { Exportação } \\
\text { ton } \\
\end{array}$ & $\begin{array}{c}\text { Produção } \\
\text { ton } \\
\end{array}$ & $\begin{array}{c}\text { Mercado } \\
\text { interno } \\
\text { ton }\end{array}$ & $\begin{array}{c}\text { Exportação } \\
\text { ton }\end{array}$ \\
\hline Abacaxi & 26.090 & 24.556 & 1.535 & 27.402 & 25.430 & 1.972 \\
\hline Caju & 67.669 & 67.528 & 141 & 67.168 & 67.043 & 125 \\
\hline Laranja & 980.900 & 20.000 & 960.900 & 1.205 .100 & 25.000 & 1.180 .100 \\
\hline Maracujá & 67.240 & 66.992 & 248 & 71.000 & 66.512 & 4.489 \\
\hline
\end{tabular}

Fonte: IBRAF (Instituto Brasileiro de Frutas)

ton: toneladas

Quadro 5. Mercado industrial de polpas de frutas, em toneladas, no período de 1995/96*

\begin{tabular}{|c|c|c|c|c|c|c|}
\hline \multirow{2}{*}{$\begin{array}{c}\text { Polpas } \\
\text { de frutas }\end{array}$} & \multicolumn{3}{|c|}{1995} & \multicolumn{3}{|c|}{1996} \\
\hline & $\begin{array}{c}\text { Produção } \\
\text { ton }\end{array}$ & $\begin{array}{c}\text { Mercado } \\
\text { interno } \\
\text { ton }\end{array}$ & $\begin{array}{c}\text { Exportação } \\
\text { ton }\end{array}$ & $\begin{array}{c}\text { Produção } \\
\text { ton }\end{array}$ & $\begin{array}{c}\text { Mercado } \\
\text { interno } \\
\text { ton }\end{array}$ & $\begin{array}{c}\text { Exportação } \\
\text { ton }\end{array}$ \\
\hline Banana & 4.363 & 76 & 4.287 & 4.033 & 81 & 3.952 \\
\hline Goiaba & 39.702 & 39.440 & 262 & 37.520 & 37.216 & 304 \\
\hline Mamão & 725 & 7 & 718 & nd & nd & nd \\
\hline Manga & 2.500 & 400 & 2.100 & 2.550 & 400 & 2.150 \\
\hline
\end{tabular}

Fonte: IBRAF (Instituto Brasileiro de Frutas)

nd: não disponível ton: toneladas 
Além da grande produção interna, são importadas diversas variedades de frutas, tanto frescas como secas, especialmente maçã e pêra (Quadro 6).

Quadro 6. Importações brasileiras de frutas frescas e secas, em toneladas, no período de 1997/98*.

\begin{tabular}{|c|c|c|}
\hline Frutas & $\begin{array}{c}1997 \\
\text { ton }\end{array}$ & $\begin{array}{c}1998 \\
\text { ton }\end{array}$ \\
\hline Banana & 0,5 & 36 \\
\hline Tâmara fresca & 0,4 & nd \\
\hline Tâmara seca & 160 & nd \\
\hline Figo seco & 903 & nd \\
\hline Abacaxi & 51 & 9 \\
\hline Abacate & 5 & 18 \\
\hline Goiaba e manga & 13 & 10 \\
\hline Laranja & 1.398 & 3.527 \\
\hline Tangerina & 2.771 & 5.149 \\
\hline Limão e limas & 1.126 & 744 \\
\hline Outros cítricos & 1,5 & nd \\
\hline Uva & 23.182 & 26.520 \\
\hline Uva seca & 16.418 & nd \\
\hline Melancia & 89 & nd \\
\hline Melão & 63 & 97 \\
\hline Maçã & 120.386 & 123.559 \\
\hline Pêra & 162.218 & 116.934 \\
\hline Marmelo & 96 & nd \\
\hline Damasco & 220 & nd \\
\hline Cereja & 993 & nd \\
\hline Pêssego & 8.128 & 5.444 \\
\hline Nectarina & 9.221 & 6.048 \\
\hline Ameixa & 23.329 & 18.406 \\
\hline Morango & 200 & 121 \\
\hline Framboesa e amora & 8 & nd \\
\hline Groselhas & 0,7 & nd \\
\hline Quiwi & 17.702 & 12.770 \\
\hline Outras frutas & 2.362 & 2.261 \\
\hline
\end{tabular}

Fonte: IBRAF (Instituto Brasileiro de Frutas)

nd: não disponivel ton: toneladas

O valor comercial das frutas pode ser reduzido, tanto para o produtor como para o industrial ou o comerciante, quando não são observados cuidados na fase de pós-colheita, no transporte, no armazenamento e na manipulação, propiciando sua deterioração (TAYLOR 1997). 
Para que os produtos de frutas sejam de boa qualidade, é necessário que a matéria-prima seja colhida e transportada de forma satisfatória, além da utilização de processamento tecnológico adequado e de boas práticas de transporte, armazenamento e comercialização, por parte de produtores, indústria e comércio, atitudes das quais o consumidor depende para obter alimentos que não causem danos à sua saúde.

Depreende-se, dai, a importância do uso de frutas frescas e sadias, para evitar que microrganismos como bactérias, leveduras e fungos possam infectá-las, causando podridão; há que observar, ainda, que insetos, ácaros e roedores também podem contribuir para a deterioração do vegetal.

A atuação de órgãos públicos na elaboração de legislação de alimentos e na fiscalização dos diferentes setores da cadeia alimenticia é importante, para garantir ao consumidor uma boa qualidade dos produtos adquiridos.

A Portaria $\mathrm{n}^{\circ} 1.428 / 93$, do Ministério da Saúde (BRASIL 1993), determina que os estabelecimentos relacionados à área de alimentos adotem programas de Boas Práticas de Produção, visando uma melhor qualidade dos produtos alimentícios que, juntamente com o Código de Defesa do Consumidor, Lei $n^{\circ}$ 8.078/90 (BRASIL 1990) e da legislação de alimentos, atuam na proteção da saúde do consumidor.

Enquanto a Portaria $n^{\circ} 1.428 / 93$ e o Código de Defesa do Consumidor são publicações recentes, os padrões de identidade e qualidade para os produtos alimenticios e, especificamente, para produtos de frutas sob legislação do Ministério da Saúde (como definição, características gerais, organolépticas, físico-químicas, microbiológicas e microscópicas), foram estabelecidos com a aprovação das Normas Técnicas Especiais constantes da Resolução n ${ }^{\circ}$ 12/78, da Comissão Nacional de Normas e Padrões para Alimentos (CNNPA) (BRASIL 1978a), com efeito em todo o território nacional e pelo Decreto Estadual n ${ }^{\circ}$ 12.486/78 (SÃO PAULO 1978), com abrangência no Estado de São Paulo. A essa normatização seguem-se as Resoluções $\mathrm{n}^{\text {os }}$ 9/78 e 15/78, da Câmara Técnica de Alimentos (CTA) do Conselho Nacional de Saúde (CNS) (BRASIL 1978bc) e que vigoram até hoje, tendo havido atualização apenas para os padrões microbiológicos, através da Portaria $n^{\circ} 451 / 97$, da Secretaria de Vigilância Sanitária (SVS), do Ministério da Saúde (MS) (BRASIL 1997). 
Para os produtos de frutas, geléia, doce em pasta e fruta em calda, que serão abordados neste estudo, a legislação estabelece, no que se refere à definição, caracteristicas gerais, de higiene, microscópicas e microbiológicas, especificamente quanto a bolores, o seguinte:

Geléia de fruta (Resoluções $n^{\circ} 12 / 78$ da CNNPA e $n^{\circ}$ 15/78 da CTA/CNS e Decreto Estadual $\left.n^{\circ} 12.486 / 78\right)$ :

Definição: é o "produto obtido pela cocção de frutas inteiras ou em pedaços, polpa ou suco de frutas, com açúcar e água e concentrado até consistência gelatinosa".

Caracteristicas gerais: o "produto deve ser preparado de frutas sãs e limpas, isentas de matéria terrosa, de parasitos, de detritos animais ou vegetais, e de fermentações...".

Características microscópicas: "ausência de sujidades, parasitos e larvas".

Padrão microbiológico (Portaria n $451 / 97$ da SVS/MS): "após 10 dias de incubação a $35^{\circ} \mathrm{C}$, não devem existir sinais de alteração das embalagens, nem quaisquer modificações fisicas, químicas ou organolépticas do produto".

Doce de fruta em pasta (Resolução $n^{\circ}$ 9/78 da CTA/CNS e Decreto Estadual $\left.\mathrm{n}^{\circ} 12.486 / 78\right)$ :

Definição: é "o produto resultante do processamento adequado das partes comestiveis desintegradas de vegetais, com açúcares, com ou sem a adição de água, pectina, ajustador de $\mathrm{pH}$ e outros ingredientes e aditivos permitidos por estes padrões até uma consistência apropriada, sendo finalmente acondicionado de forma a assegurar sua perfeita conservação".

Higiene: "os doces em pasta obedecerão aos requisitos gerais de higiene e aos requisitos especificos de higiene fixados para os vegetais e as frutas processadas, não podendo apresentar sujidades, partes de insetos, fungos, leveduras, detritos orgânicos e de outras substâncias estranhas em quantidade que indique a utilização de ingredientes em condições insatisfatórias ou tecnologia de processamento inadequada". 
Padrão microbiológico (Portaria $\mathrm{n}^{\circ} 451 / 97$ da SVS/MS): limite de $10^{3} / \mathrm{g}$ para bolores e leveduras.

Compota ou fruta em calda (Resolução $n^{\circ} 12 / 78$ e Decreto Estadual $n^{\circ}$ 12.486/78):

Definição: é "o produto obtido de frutas inteiras ou em pedaços, com ou sem sementes ou caroços, com ou sem casca e submetidas a cozimento incipiente, enlatadas ou envidradas, praticamente cruas, cobertas com calda de açúcar. Depois de fechado em recipientes, o produto é submetido a um tratamento térmico adequado".

Características gerais: "o produto deverá ser preparado com frutas sãs, limpas, isentas de matéria terrosa, parasitos e de detritos animais ou vegetais...".

. Características microscópicas: "ausência de sujidades, parasitos e larvas".

Padrão microbiológico (Portaria n ${ }^{0}$ 451/97 da SVS/MS): "após 10 dias de incubação a $35^{\circ} \mathrm{C}$, não devem existir sinais de alterações das embalagens, nem quaisquer modificações fisicas, químicas ou organolépticas do produto".

Assim, de acordo com a legislação, os produtos de frutas mencionados não poderão apresentar, entre outros, sujidades ou matérias estranhas (como as de natureza biológica) e fungos (exceto doce em pasta, que apresenta limite de tolerância para fungos viáveis).

No entanto, como citado no Defect Action Level (DAL), do Food and Drug Administration (FDA), órgão que legisla sobre alimentos e medicamentos nos Estados Unidos, é quase impossível plantar, colher e processar alimentos totalmente isentos dessas matérias estranhas; além do que, a utilização de produtos químicos para controle ou extermínio de contaminantes biológicos podem gerar resíduos químicos, os quais, por sua vez, podem ser prejudiciais à saúde do consumidor (CENTER FOR FOOD SAFETY AND APPLIED NUTRITION 1989).

A análise microscópica dos produtos de frutas processadas permite avaliar as condições sanitárias da matéria-prima utilizada ou do seu processamento, através de métodos de isolamento dessas matérias estranhas (principalmente as de natureza biológica) e da contagem de filamentos de hifas de fungos, viáveis ou não. 


\subsection{FUNGOS}

Os fungos (bolores e leveduras), por serem pouco exigentes em nutrientes, podem se desenvolver em diversos habitats como solo, animais e plantas, assim como em produtos processados, como alimentos, papel, lentes e tantos outros (BONONI 1998). Podem ser usados em processos biotecnológicos, como na indústria alimentícia, para a produção de alimentos fermentados, como de soja e de arroz, vinhos e cervejas; na indústria farmacêutica, cosmética e têxtil, para a produção de ácidos como fumárico e glucônico, além de enzimas e vitaminas, como a riboflavina (MISLIVEC 1993, BONONI 1998).

Apesar de serem benéficos ao homem, os fungos também podem acarretar prejuízos; na agricultura os fungos saprófitas podem causar a deterioração de diversos produtos agricolas, como sementes, grãos e alimentos embalados ou não, entre outros; quanto aos fungos parasitas, podem causar doenças nas culturas no campo, como a ferrugem em ameixa, figo e pêssego, e o oideo, em uva (LAZZARI 1997).

Tanto as fruteiras de clima tropical como as de clima temperado podem ser atacadas por várias espécies de fungos, que causam doenças em diferentes partes da planta (Quadro 7), podendo provocar perdas econômicas de grande vulto; como exemplo, a fusariose do abacaxi, que provoca perdas de até $80 \%$ da produção (CUNHA e col. 1994), ou as podridões do engaço, que se manifestam na banana após a colheita (MEDINA e col. 1978b) 
Quadro 7. Principais espécies de fungos causadores de doenças em algumas fruteiras.

\begin{tabular}{|c|c|c|}
\hline Fruteiras & Fungos & Doenças \\
\hline Abacaxizeiro & $\begin{array}{l}\text { Fusarium moniliforme Sheld var. subglutinans } \\
\text { Thielaviopsis paradoxa Hoehn e Ceratocystis paradoxa } \\
\text { Moreau } \\
\text { Phytophthora cinnamomi Rands }\end{array}$ & $\begin{array}{l}\text { Gomose } \\
\text { Podridão-negra } \\
\text { Podridão-da-raiz }\end{array}$ \\
\hline Ameixeira & $\begin{array}{l}\text { Monilia fructicola } \\
\text { Physalospora malorum Hesler } \\
\text { Tranzschelia pruni-spinosae (Pers.) Diet. }\end{array}$ & $\begin{array}{l}\text { Podridão-parda } \\
\text { Podridão-preta } \\
\text { Ferrugem }\end{array}$ \\
\hline Bananeira & $\begin{array}{l}\text { Sclerotinia sclerotionum } \\
\text { Phyllostictina musarum } \\
\text { Botryodiplodia theobromae } \\
\text { Pyricularia grisea } \\
\text { Colletotrichum musae } \\
\text { Mycosphaerella musicola Leach } \\
\text { Mycosphaerella fijiensis } \\
\text { Fusarium oxysporum F.Smith f. cubense Snyder \& } \\
\text { Hansen }\end{array}$ & $\begin{array}{l}\text { Podridão-do-fruto } \\
\text { Sarna-do-fruto } \\
\text { Podridão-do-pedúnculo } \\
\text { Pinta-de-Pyricularia } \\
\text { Antracnose } \\
\text { Sigatoga-amarela } \\
\text { Sigatoga-negra } \\
\text { Mal-do-panamá/fusariose }\end{array}$ \\
\hline Figueira & Phisopella fici & \begin{tabular}{|l|} 
Ferrugem \\
\end{tabular} \\
\hline Goiabeira & $\begin{array}{l}\text { Puccina psidii Wint } \\
\text { Sphaceloma psidii }\end{array}$ & $\begin{array}{l}\text { Ferrugem-da-goiabeira } \\
\text { Antracnose }\end{array}$ \\
\hline Morangueiro & $\begin{array}{l}\text { Micosphaerella fragariae } \\
\text { Botrytis cinerea }\end{array}$ & $\begin{array}{l}\text { Mancha-das-folhas } \\
\text { Mofo-cinzento }\end{array}$ \\
\hline Pessegueiro & $\begin{array}{l}\text { Cladosporium carpophilum Thum } \\
\text { Monilia fructicola (Wint.) Honey } \\
\text { Glomerella cingulata (Ston) Spauld \& Shrenck } \\
\text { Colletotrichum gloesporioides Penz. } \\
\text { Tranzschelia pruni-spinosae (Pers.) Diet. } \\
\text { Taphrina deformans (Berck.) }\end{array}$ & $\begin{array}{l}\text { Sarna-do-pessegueiro } \\
\text { Podridão-parda } \\
\text { Antracnose } \\
\text { Antracnose } \\
\text { Ferrugem } \\
\text { Tafrina-crespeira }\end{array}$ \\
\hline Videira & $\begin{array}{l}\text { Uncinula necator Burril } \\
\text { Sphaceloma ampelinum e Gloeosporium ampelophagum } \\
\text { Plasmopara viticola } \\
\text { Melanconium fuligeneum } \mathrm{Cav} \\
\text { Glomerella cingulata Ston }\end{array}$ & $\begin{array}{l}\text { Oideo } \\
\text { Antracnose } \\
\text { Mildio } \\
\text { Podridão-amarga } \\
\text { Podridão-da-uva-madura }\end{array}$ \\
\hline
\end{tabular}

Fontes: CUNHA e col. (1994); MEDINA (1978a,b,c); GOMES (1973); CASTRO e col. (1994); BORGES e col. (1994); GONZAGA NETO e SOARES (1995); SANTOS (1993); RASEIRA e col. (1993)

Os esporos de fungos podem chegar à planta pela ação do vento, da chuva e por insetos (TAYLOR 1997) e as frutas podem apresentar em sua superficie, além dos contaminantes provenientes das fruteiras, outros advindos do solo e da água, 
formando uma flora composta principalmente por bolores e leveduras (FRAZIER e WESTHOFF 1993, JAY 1994).

Outras contaminações podem ocorrer pelos equipamentos utilizados na colheita, pelo uso de caixas e de água contaminada para lavagem da fruta, por armazenamento em locais sujos ou, ainda, por lesões do epicarpo da fruta causadas pelo contato com superficies irregulares de equipamentos utilizados para lavagem e seleção, facilitando o desenvolvimento de fungos (TAYLOR 1997).

A fruta mantida em caixas ou outros espaços confinados, também forma um microclima favorável ao desenvolvimento dos fungos que podem estar presentes na lesão causada pela colheita ou pelo manuseio inadequado. A saída de líquidos tissulares da fruta facilita a germinação de esporos e, mesmo que os fungos não se desenvolvam o suficiente para produzir a doença na fruta, na industrialização, após o processamento, podem deteriorar o produto (TAYLOR 1997).

Pelas características que têm os fungos de se desenvolverem em substratos que apresentam diferentes níveis de atividade de água (Aa), valores de $\mathrm{pH}$ variados e uma ampla faixa de temperatura, seu crescimento em produtos alimentícios é favorecido, causando alterações na composição quimica, estrutura e aparência desses alimentos, levando à rejeição com conseqüente perda, tanto da matéria-prima como do produto acabado (TANIWAKI 1996).

Segundo SAMSON e col. (1995), na industrialização de alimentos é recomendado o monitoramento regular de fungos do ambiente, tanto das áreas de trabalho como de equipamentos, para prevenir a esporulação. Os fungos filamentosos, além de poderem causar alergia em individuos susceptiveis, ao utilizarem o vegetal como substrato para o seu desenvolvimento, produzem metabólitos secundários, podendo, alguns deles, serem tóxicos para o homem, como as micotoxinas, as quais, por serem compostos termo-estáveis, não são destruídas durante o processamento do alimento, permanecendo no produto.

Os fungos filamentosos ou bolores são formados por filamentos denominados hifas (septadas ou não), que crescem e se ramificam, formando o micélio. Este tem as funções de fixação do bolor ao substrato (micélio vegetativo) e de reprodução 
(micélio reprodutivo) com a produção de esporos, os quais, em condições favoráveis de umidade e temperatura, germinam produzindo hifas (FRANCO e LANDGRAF 1996, LAZZARI 1997).

De acordo com YOKOYA (1993), a presença de hifas de fungos em produtos de frutas e de tomate termoprocessados, indicam utilização de matéria-prima contaminada com fungos ou condições inadequadas de higiene durante 0 processamento. Apesar dos fungos serem inativados na etapa de processamento térmico, durante a industrialização e, portanto, com resultados negativos nas culturas microbiológicas, suas estruturas (hifas) permanecem no produto, freqüentemente de forma fragmentada.

No entanto, bolores termorresistentes do gênero Byssochlamys, como B. nivea e $B$. fulva, têm sido citados como agentes deteriorantes de sucos e outros produtos processados de frutas, por serem capazes de sobreviver ao tratamento térmico utilizado. Esses bolores, provenientes do solo, contaminam o produto quando a matéria-prima vegetal não é lavada adequadamente e resíduos de terra ficam aderidos na sua superficie (EIROA 1989).

Morango, ameixa e uva e seus produtos derivados seriam mais susceptiveis à contaminação com fungos termorresistentes, tanto do gênero Byssochlamys como Talaromyces e Neosartorya, enquanto pêssego, abacaxi e maçã seriam mais resistentes; Byssochlamys nivea e Byssochlamys fulva são, ainda, capazes de produzir micotoxinas, como a patulina (TOURNAS 1994, BEUCHAT 1998).

O método utilizado para a contagem de filamentos micelianos foi desenvolvido por Howard, levando seu nome e sendo inicialmente usado para avaliar a contaminação fúngica de tomates, passou depois a servir, também, para produtos de frutas.

O método Howard pressupõe que haja uma correlação entre a contaminação por fungos presentes nos frutos e a contagem de hifas remanescentes no produto (PATEL e col. 1991, YOKOYA 1993). A contagem é realizada ao microscópio e cada campo observado é computado como positivo ou negativo, não levando em consideração o número de fragmentos de hifas presentes. 
Como outros fatores podem influenciar na contagem de fragmentos de hifas, como a espécie de fungo infectante do fruto (que pode apresentar tipos e quantidade de hifas diferentes) e as variações no seu processamento, como a utilização de moinhos e homogeneizadores que fragmentam as hifas, resultando em um grande número de filamentos (OLSON 1980, BANDLER e col. 1987, YOKOYA 1993), métodos alternativos têm sido propostos para avaliar a proporção de frutos utilizados como matéria prima que são atacados por fungos.

JARVIS (1977) propôs um método colorimétrico para dosar glucosaminas obtidas pela hidrólise alcalina da quitina, que é o principal componente da parede celular das hifas de fungos e que, por não estar presente nos vegetais, poderia ser utilizado em produtos de tomate, em substituição ao método Howard; no entanto, o autor não encontrou correlação entre os resultados obtidos nos dois métodos.

BISHOP e col. (1982) também estudaram a aplicabilidade do método de dosagem de glucosaminas por colorimetria, para estimar o nivel de contaminação de fungos em produtos de tomate utilizando culturas dos fungos Alternaria temuis, Colletotrichum phomoides, Fusarium oxysporum e Geotrichum candidum, adicionadas a catchup, purê e extrato de tomate, além de moscas e larvas (que apresentam quitina no exoesqueleto). Como resultados, encontraram uma correlação estatisticamente significante entre a contagem de fungos pelo método Howard e o conteúdo de glucosamina fúngica e a utilização de 60 fragmentos de insetos/100 g de amostra não interferiu nos resultados.

ROBERTSON e col. (1988) desenvolveram um método utilizando imunofluorescência, para facilitar a identificação das hifas de fungos ao microscópio, empregando anticorpos fluorescentes dos principais fungos que atacam os tomates.

COUSIN e col. (1984) realizaram estudos para verificar a utilização do método colorimétrico (JARVIS 1977) em produtos processados de tomate e de outras frutas (néctares e purês), os quais foram hidrolizados, após adicionar culturas de Alternaria alternata, Alternaria solani, Colletotrichum coccodes, Fusarium oxysporum, Geotrichum candidum, Rhizopus stolonifer, além de moscas do gênero Drosophila. Os autores verificaram que a quitina da mosca não interferiu nos 
resultados para fungos, mas não encontraram correlação entre o método estudado e o método Howard.

LIN e COUSIN (1985), baseando-se na detecção de glucosaminas, propuseram um método utilizando cromatografia líquida de alta eficiência (CLAE), adicionando 6 espécies de fungos associados a produtos de frutas, a purê e catchup de tomate, purê de pêssego, morango congelado e néctar de damasco, além da adição de mosca-da-fruta. Como as espécies de fungos utilizadas apresentavam diferentes quantidades de quitina nas hifas, a dosagem de glucosaminas, obtida pela hidrólise da quitina, não refletiu a verdadeira contaminação por fungos; quanto ao conteúdo de quitina da mosca-da-fruta, este é menor que o dos fungos testados e assim, haveria interferência nos resultados somente com altos níveis de contaminação.

BERTONI e col. (1994) estudaram a utilização do ergosterol (que é um componente da parede celular dos fungos) para avaliar a contaminação fúngica do tomate "in natura", em paralelo com o método Howard, analisando produtos industrializados de tomáte. No entanto, não encontraram correlação entre a concentração de ergosterol e a contagem de fungos.

Em 1995, BATTILANI e col analisaram produtos de tomate utilizando métodos de determinação da concentração de ergosterol e contagem de fungos pelo método Howard, para os quais encontraram correlação. Em outro estudo, BATTILANI e col. (1996) compararam os métodos de determinação da área infectada do tomate, o método Howard e de determinação de ergosterol por cromatografia líquida de alta eficiência (CLAE), para avaliar a contaminação de tomates infectados artificialmente, com sete espécies de fungos. Os resultados mostraram haver diferenças entre os métodos, uma vez que avaliam diferentes aspectos da presença do fungo, isto é, a área infectada mede a capacidade do fungo em modificar as características visiveis do fruto, o método Howard mede o desenvolvimento do micélio e só quantifica os filamentos, enquanto o método do ergosterol quantifica todas as formas de desenvolvimento do fungo, como micélio e esporos, mas só daqueles que produzem esteróis. 
Métodos imunológicos também têm sido desenvolvidos para avaliar a contaminação fúngica, uma vez que as proteínas da parede celular dos fungos podem ser utilizados para produzirem anticorpos.

De acordo com PATEL e col. (1991) a utilização de métodos de detecção de fungos por imunofluorescência, como o desenvolvido por Notermans e Heuvelman em 1985, eliminam a dificuldade que há no método Howard de distinguir os filamentos de fungos misturados aos tecidos vegetais do tomate, reduzindo, ainda, o tempo de análise.

Em outro estudo LIN e col. (1986) utilizaram o método de imunoensaio (ELISA) para deteç̧ão de fungos em produtos de tomate, após a obtenção de antisoros de Alternaria alternata, Geotrichum candidum e Rhizopus stolonifer produzidos por coelhos. A reação cruzada entre as três espécies de fungos foi baixa e os autores encontraram uma maior sensibilidade deste método em relação aos métodos químicos propostos, sendo a interferência dos elementos histológicos da fruta desprezivel. É menos subjetivo que o método Howard e mais sensível, mas, segundo os autores, seria necessário a obtenção de um "pool" de anticorpos para detecção de várias espécies de fungos que poderiam estar presentes na amostra do produto.

LIN e COUSIN (1987) também utilizaram o método de imunoensaio (ELISA) para detectar os fungos Alternaria alternata, Geotrichum candidum e Rhizopus stolonifer em purês de tomate e de pêssego, néctar de damasco, suco de abacaxi, pão fresco e queijo tipo ricota. O método apresentou correlação com a quantidade de fungo adicionado ao produto; foram detectados fungos viáveis e não viáveis e houve correlação entre o método proposto e o método Howard, sendo o ELISA melhor para detectar baixos níveis de contaminação füngica, podendo, ainda, discriminar os grupos ou espécies de fungos presentes.

COUSIN e col. (1990) utilizaram o método ELISA para deteç̧ão de antigenos dos fungos Botrytis e Monascus em amostras comerciais de sucos de maçã, laranja e uva, geléias de morango, cereja e damasco e produtos de tomate, entre outros; os produtos testados não continham antígenos para Monascus spp, assim 
como os sucos de maçã e laranja e a geléia de damasco não apresentaram reação para Botrytis, enquanto a geléia de uva apresentou altos niveis de antígeno para esse fungo.

PATEL e col. (1991) desenvolveram um método imunoquímico para detecção de fungos em pasta de tomate, no qual um anticorpo específico foi marcado diretamente com uma enzima, visando um método analítico mais rápido que aqueles anteriormente propostos. Amostras de pasta de tomate com contagens conhecidas de filamentos de fungos pelo método Howard, foram testadas com anticorpos policlonais produzidos por Alternaria alternata, Botrytis cinerea, Fusarium solani, Mucor pyriformis e Rhizopus stolonifer e dois conjugados enzimáticos. Os autores concluíram que o método poderia ser adotado em substituição ao método Howard, por ser mais rápido e não estar sujeito à interpretação do analista.

COUSIN (1996), em revisão bibliográfica, avaliou os métodos propostos para dosagem da glucosamina resultante da hidrólise da quitina presente na parede celular dos fungos e compara os resultados obtidos. Inicialmente, a dosagem de quitina foi utilizada para verificar a contaminação de tecidos vegetais por fungos; em seguida, para cereais e grãos armazenados, enquanto que para produtos industrializados de frutas foi sugerido como alternativa ao método Howard. Para estes produtos, o autor considera o método de dosagem de glucosamina viável, necessitando, no entanto, de simplificação na metodologia analítica, dos equipamentos, tempo de análise e aumento da sensibilidade do método.

Embora vários métodos tenham sido propostos e continuem sendo desenvolvidas pesquisas para detecção e quantificação de fungos em produtos de tomate e de frutas, a metodologia oficial da Association of Official Analytical Chemists International (AOAC International) para contagem de filamentos de fungos ainda é o método Howard, que é usado em vários países, como indicador da qualidade da matéria-prima utilizada para a elaboração desses produtos, permitindo estabelecer níveis de tolerância para filamentos de hifas nesses alimentos.

No Brasil, a legislação de alimentos (Resolução $\mathrm{n}^{0}$ 12/78 da CNNPA e Decreto Estadual $n^{\circ} 12.486 / 78$ ) estabelece limite de tolerância de $40 \%$ de campos 
positivos apenas para extrato de tomate, não fazendo menção a outros produtos de tomate ou qualquer produto de frutas.

Nos Estados Unidos, a Food and Drug Administration (FDA) estabeleceu, para produtos alimenticios, niveis de ação para defeitos naturais (Defect Action Levels - DALs), e os definiu como sendo os "niveis correntes para defeitos naturais e inevitáveis em alimentos para uso humano que, quando presentes, não causam perigo à saúde".

Os niveis de ação são valores estabelecidos para contagem de fungos e de matérias estranhas que, quando detectados na análise do alimento, levam a um procedimento legal de retirada do produto do mercado, como sendo adulterado e, segundo o FDA, esses valores não representam a média dos resultados encontrados nas análises de alimentos realizadas nos seus laboratórios. Assim, em análises de néctares e purês de damasco, pêssego e pêra realizadas pelo FDA (BANDLER e col. 1982) para contagem de filamentos micelianos pelo método Howard, $100 \%$ das amostras continham até $10 \%$ de campos positivos (exceto néctar de damasco que apresentou até $15 \%$ ), enquanto o valor estabelecido no DAL é de $12 \%$ de campos positivos.

Entre os produtos que apresentam niveis de ação para contagem de filamentos micelianos, encontram-se os derivados de tomate e de frutas, com valores mais elevados para os produtos das frutas mais delicadas e susceptíveis à contaminação por fungos, como geléia de groselha e de morango, framboesa e amora enlatadas ou congeladas e valores mais baixos para purê de maçã, néctares de pêssego, de pêra e de damasco, suco de abacaxi e abacaxi enlatado (CENTER FOR FOOD SAFETY AND APPLIED NUTRITION 1989).

As publicações apresentando resultados de análises empregando o método Howard são em número reduzido e referem-se principalmente a produtos de tomate (LEITÃO e MENEZES 1967/68, SILVA e col. 1975, GHERARDí e VICINI 1981, ZAMBONI e col. 1980, CICHOWICZ e col. 1982, GOULART e CARVALHO 1983). Mas há outros trabalhos, também em pequeno número, como de GHERARDI e VICINI (1981) que analisaram, além de suco de tomate, amostras de néctares de 
damasco, pêssego, pêra e maçã, encontrando amostras com até $100 \%$ de campos positivos com filamentos de fungos.

ZAMBONI e col. (1981a) analisaram amostras de sucos de maracujá, caju e uva, sendo o suco de maracujá o que apresentou maiores percentuais de filamentos de fungos.

Em outro trabalho, ZAMBONI e col. (1981b) estudaram amostras de doces em pasta, encontrando para o doce de figo valor máximo de $20 \%$ de campos positivos para filamentos micelianos, para marmelada e pessegada máximo de $30 \% \mathrm{e}$ para a goiabada até $100 \%$ de campos positivos.

Como os poucos trabalhos publicados divergem quanto à metodologia de análise utilizada, é dificil comparar os resultados, sendo importante uma uniformização da metodologia analítica entre os laboratórios.

Entre os fungos que podem contaminar os alimentos encontra-se o Geotrichum candidum Link, presente no solo e em frutas e hortaliças em decomposição. No campo, seus esporos e fragmentos de micélio são transportados pela mosca-da-fruta que, assim, contamina vegetais sãos, causando, entre outros, a podridão ácida em frutas citricas e tomates (JAY 1994).

$\mathrm{Na}$ indústria alimentícia o Geotrichum candidum, também chamado de fungo da maquinaria, é considerado um indicador das condições de higiene de equipamentos e utensilios utilizados para o processamento de tomate e frutas (JAY 1994). Como é sensivel ao cloro (que rotineiramente é usado na higienização de superficies de equipamentos) e ao calor, pode ser evitado o seu crescimento ou ser removido quando são observados procedimentos adequados de limpeza (CICHOWICZ 1993, EISENBERG 1993).

Esse fungo apresenta como característica o desenvolvimento e aderência do micélio à superfície de equipamentos e utensilios utilizados no processamento dos vegetais, como madeira, metal, borracha e aço inoxidável; em contato com o alimento, esse micélio se desprende, causando contaminação do produto final (JAY 1994). 
Assim, enquanto o método Howard avalia a contaminação da matéria-prima (tomate e frutas), por contagem de filamentos micelianos não viáveis, que permanecem no produto final após o processamento térmico e, também, a presença de hifas viáveis que possam se desenvolver em etapas subseqüentes, a contagem de hifas de Geotrichum indica, principalmente, as condições de higiene de equipamentos e utensílios utilizados durante a fabricação.

CICHOWICZ e EISENBERG (1974), com a finalidade de avaliar as condições de higiene da indústria durante o processamento de produtos de frutas, analisaram amostras de coquetel de frutas e pêssego enlatado colhidas antes e após a limpeza dos equipamentos da fábrica, verificando que havia diminuição considerável do número de fragmentos de hifas de Geotrichum no produto, após a higienização dos equipamentos.

De acordo com EISENBERG e CICHOWICZ (1977), em estudos realizados nos Estados Unidos pelos laboratórios do FDA com 500 amostras de pêssego enlatado colhidas no mercado, foram encontrados até 11.730 fragmentos de micélio de Geotrichum/500g de amostra e apenas 17 amostras isentas; em 500 amostras de produtos de abacaxi em fatias e triturado, 170 amostras não continham o fungo e 1 amostra apresentou 18.525 fragmentos $/ 500 \mathrm{~g}$ de amostra.

O Geotrichum candidum viável foi isolado de produtos como bolo, suco de laranja congelado, azeitonas verdes, queijos, produtos de tomate e de leite; enquanto micélios mortos foram encontrados em produtos processados de pêra, maçã, milho, batata, cenoura, citros e em alimentos congelados como milho e feijão verde (CICHOWICZ 1993).

ZAMBONI (1986) colheu amostras em indústrias processadoras de extrato de tomate e de doces em pasta, tanto da raspagem dos equipamentos como dos produtos, em várias fases da produção. Verificou acentuada diminuição na contagem de filamentos de Geotrichum quando era realizada a limpeza adequada dos equipamentos e utensílios. 


\subsection{MATÉRIAS ESTRANHAS}

Matéria estranha, segundo definição da Association of Official Analytical Chemists International (AOAC International) (BOESE e CICHOWICZ 1995) é "qualquer material estranho ao produto associado com condições ou práticas inadequadas de produção, estocagem ou distribuição, incluindo sujidades, material decomposto (material em decomposição devido a causas parasíticas ou não) e materiais diversos, tais como terra, areia, vidro e outros elementos estranhos, excluindo-se as contagens bacterianas".

Essa instituição adota, também, as seguintes definições:

- sujidade: qualquer elemento estranho ao produto, advindo de contaminação animal (roedores, insetos ou pássaros) ou qualquer outro material indesejável devido a condições inadequadas de manuseio.

- sujidade leve: a sujidade que, por ser lipofilica e formada por elemento mais leve que a particula do produto alimentício, é isolada do mesmo por flutuação em um sistema contendo óleo e água (insetos e larvas vivas e/ou mortas, ovos ou fragmentos de insetos, ácaros vivos e/ou mortos, pêlos de roedores, bárbulas de penas).

- sujidade pesada: a sujidade formada por elemento mais pesado que o constituinte do alimento, que separa-se do produto por sedimentação, quando imersa em liquidos como clorofórmio ou outros (excrementos de roedores, dejeções de insetos, areia, terra, partícula metálica, vidro, etc.)

- sujidade separada por peneira: a sujidade de tamanho específico, separada quantitativamente do produto, usando-se peneiras com malhas de aberturas adequadas.

Embora os alimentos dificilmente estejam isentos de matérias estranhas, é possível seu controle em níveis aceitáveis, para que não causem danos à saúde humana.

Entre as matérias estranhas de origem biológica, os insetos adultos e, também, as fases intermediárias, como ovos, larvas e pupas, são encontrados com maior freqüência. 
As fruteiras, de um modo geral, estão sujeitas, além da infestação por fungos, conforme citado anteriormente, ao ataque de pragas, como os insetos, cujas populações ou podem ser mantidas sob controle, através de tratamento fitossanitário, ou são consideradas pragas (Quadro 8), provocando danos quali-quantitativos às fruteiras e causando prejuizos econômicos.

Os insetos podem infestar alimentos, "in natura" e processados, produzindo perdas e facilitando a invasão de bactérias e fungos, com a conseqüente deterioração do produto. A infestação pode ocorrer no campo, em locais de armazenamento, durante o transporte e no comércio (GRAVANI 1985).

Quadro 8. Principais espécies de insetos consideradas pragas de algumas fruteiras.

\begin{tabular}{|c|c|c|}
\hline Fruteiras & Insetos & Nome popular \\
\hline Abacaxizeiro & $\begin{array}{l}\text { Thecla basalides Geyer, } 1837 \\
\text { Dysmicocccus brevipes Cockerell, } 1893 \\
\text { Paradiophorus crenatus Billberg, } 1820 \\
\text { Lybindus dichrous Stal., } 1859 \\
\text { Parisoschoenus ananasi Moure, } 1976 \\
\text { Castnia icarus Cramer, } 1775\end{array}$ & $\begin{array}{l}\text { Broca-do-fruto } \\
\text { Cochonilha-do-abacaxi } \\
\text { Broca-do-colo } \\
\text { Percevejo-do-abacaxi } \\
\text { Caruncho-do-abacaxi } \\
\text { Broca-do-talo }\end{array}$ \\
\hline Ameixeira & $\begin{array}{l}\text { Quadraspidiotus perniciosus Comst., } 1881 \\
\text { Sternocolaspis quatuodecimcostata Lefèvre, } \\
1877 \\
\text { Ceratitis capitata Wied., } 1824 \\
\text { Anastrepha fraterculus Wied., } 1830 \\
\text { Grapholita molesta } \text { Busck, } 1916 \\
\end{array}$ & $\begin{array}{l}\text { Piolho ou cochonilha de São José } \\
\text { Besouro-de-limeira } \\
\text { Mosca-da-fruta } \\
\text { Mosca-da-fruta } \\
\text { Mariposa oriental }\end{array}$ \\
\hline Amoreira & $\begin{array}{l}\text { Pseudaulacaspis pentagona Targ-Tozz, } 1885 \\
\text { Automeris memusae Walker, } 1855 \\
\text { Heilipus sp } \\
\text { Bolax flavolineatus Mann., } 1829 \\
\end{array}$ & $\begin{array}{l}\text { Cochonilha branca-da-amoreira } \\
\text { Lagarta } \\
\text { Besouro } \\
\text { Besouro-pardo }\end{array}$ \\
\hline Bananeira & $\begin{array}{l}\text { Caliothrips bicinctus } \text { Bagnall, } 1919 \\
\text { Chaetanaphothrips } \text { orchidii } \\
\text { Tryphactothrips lineatus } \\
\text { Cosmopolites sordidus Germar, } 1824 \\
\text { Opogona sacchari Bojer, } 1856 \\
\text { Trigona spinipes } \text { Fabricius, } 1793 \\
\text { Pentalonia nigronervosa Coquerel, } 1859 \\
\text { Frankliniella spp }\end{array}$ & $\begin{array}{l}\text { Tripes-da-ferrugem-dos-frutos } \\
\text { Tripes-da-ferrugem-dos-frutos } \\
\text { Tripes-da-ferrugem-dos-frutos } \\
\text { Broca-do-rizoma } \\
\text { Traça-da-bananeira } \\
\text { Abelha irapuá } \\
\text { Pulgão-da-bananeira } \\
\text { Tripes-da-flor }\end{array}$ \\
\hline Figueira & $\begin{array}{l}\text { Azochis gripusalis Walk., } 1859 \\
\text { Colobogaster cyanitarsis Laporte e Gory, } 1837 \\
\text { Marshallius bonelli Boh., } 1830 \\
\text { Trachyderes thoracicus Oliv., } 1790 \\
\text { Taeniotes scalaris Fabricius, } 1781 \\
\text { Asterolecanium pustulaus Cockrell, } 1892\end{array}$ & $\begin{array}{l}\text { Broca-da-figueira } \\
\text { Coleobroca } \\
\text { Coleobroca } \\
\text { Coleobroca } \\
\text { Coleobroca } \\
\text { Cochonilha }\end{array}$ \\
\hline
\end{tabular}


Quadro 8. Principais espécies de insetos consideradas pragas de algumas fruteiras (continuação).

\begin{tabular}{|c|c|c|}
\hline Fruteiras & Insetos & Nome popular \\
\hline Goiabeira & $\begin{array}{l}\text { Trachyderes thoracicus Oliv., } 1790 \\
\text { Timocratica albella Zeller, } 1839 \\
\text { Costalimaita ferruginea vulgata Lefevre, } 1985 \\
\text { Triozoida sp } \\
\text { Ceratitis capitata Wied., } 1824 \\
\text { Anastrepha fraterculus Wied., } 1830 \\
\text { Anastrepha obliqua Macq., } 1835 \\
\text { Conotrachelus psidii Marshall, } 1922\end{array}$ & $\begin{array}{l}\text { Coleobroca } \\
\text { Broca-da-goiabeira } \\
\text { Besouro-amarelo } \\
\text { Psilideo } \\
\text { Mosca-da-fruta } \\
\text { Mosca-da-fruta } \\
\text { Mosca-da-fruta } \\
\text { Gorgulho-da-goiaba }\end{array}$ \\
\hline Marmeleiro & $\begin{array}{l}\text { Grapholita molesta Busck, } 1916 \\
\text { Seternocolaspis quatuordecimcostata Lefèvre, } \\
1877 \\
\text { Anastrepha fraterculus Wied., } 1830\end{array}$ & $\begin{array}{l}\text { Mariposa-oriental } \\
\text { Besouro-de-limeira } \\
\text { Mosca-da-fruta }\end{array}$ \\
\hline Pessegueiro & $\begin{array}{l}\text { Brachycaudus schwartzi Borner, } 1931 \\
\text { Grapholita molesta Busck, } 1916 \\
\text { Pseudalacaspis pentagona Targ-Tozz, } 1885 \\
\text { Anastrepha fraterculus Wied., } 1830 \\
\text { Anastrepha obliqua Macquart, } 1835 \\
\text { Ceratitis capitata Wied., } 1824 \\
\text { Sternocolaspis quatuordecimcostata Lefevre, } \\
1877 \\
\text { Euphoria lurida Fabr., } 1775 \\
\text { Macrodactylus pumilio Burm., } 1855 \\
\text { Bolax flavolineatus Mann., } 1829 \\
\end{array}$ & $\begin{array}{l}\text { Pulgão } \\
\text { Mariposa } \\
\text { Cochonilha } \\
\text { Mosca-da-fruta } \\
\text { Mosca-da-fruta } \\
\text { Mosca-da-fruta } \\
\text { Besouro } \\
\text { Besouro } \\
\text { Besouro } \\
\text { Besouro-pardo }\end{array}$ \\
\hline Videira & $\begin{array}{l}\text { Eurhizococcus brasiliensis Hempel, } 1922 \\
\text { Daktulosphaira vitifoliae Fitch., } 1856 \\
\text { Parthenolecanium persicae Fabricius, } 1776 \\
\text { Hemiberlesia lataniae Signoret, } 1869 \\
\text { Pseudaulacaspis pentagona Targioni Tozzetti, } \\
1885 \\
\text { Duplaspidiotus tesseratus Charmoy, } 1899 \\
\text { Duplaspidiotus fossor Newstead, } 1914 \\
\text { Icerya schrottkyi Hempel, } 1900 \\
\text { Heilpus naevulus Mannerheim, } 1836 \\
\text { Cryptoblabes gnidiella Millière, } 1864 \\
\text { Eumorpha vitis Linné, } 1758 \\
\text { Anastrepha } \text { spp. } \\
\text { Ceratitis capitata Wiedmann, } 1824 \\
\text { Maecolaspis spp. }\end{array}$ & $\begin{array}{l}\text { Pérola-da-terra } \\
\text { Filoxera } \\
\text { Cochonilha-parda } \\
\text { Cochonilha-do-lenho } \\
\text { Cochonilha-do-lenho } \\
\text { Cochonilha-do-lenho } \\
\text { Cochonilha-do-lenho } \\
\text { Cochonilha-algodão } \\
\text { Maromba ou trombeta } \\
\text { Traça-dos-cachos } \\
\text { Mandarova-da-uva } \\
\text { Mosca-da-fruta } \\
\text { Mosca-da-fruta } \\
\text { Besouro-desfolhador }\end{array}$ \\
\hline
\end{tabular}

Fontes: SIMÃO (1971), GOMES (1973), GALLO e col. (1988), RASEIRA e col. (1993). CASTRO e col. (1994), LARA e col. (1998), FANCELLI e MESQUITA (1998); PEREIRA e BORTOLI (1998), HICKEL (1998) 
Embora menos freqüentes que os insetos, os ácaros são encontrados em diversos alimentos, como cereais, carnes, queijos, frutas e seus produtos derivados, sendo provenientes do solo ou transportados por roedores, aves $\mathrm{e}$ insetos (FLECHTMANN 1986).

Ácaros também podem causar prejuizos à lavoura, como o ácaro alaranjado do abacaxizeiro, os ácaros rajado e prateado do pessegueiro (GALLO 1988), o ácaro branco da goiabeira (PEREIRA e BORTOLI 1998) e os ácaros rajado e vermelho da videira (HICKEL 1998).

Os produtos alimentícios estão sujeitos à infestação por várias espécies de ácaros; conforme citado por OLSEN (1998a), Hughes (1976) relacionou 64 espécies de ácaros infestando produtos armazenados, Smiley (1983) 114, Pugh (1996) encontrou 12 espécies em cereais e Olsen (1983) cita 22.

Por possuírem alérgenos no corpo, nas secreções e nas dejeções, ácaros como Tyrophagus putrescentiae, Suidasia pontifica e Dermatophagoides pteronyssimus, entre outros, podem desencadear reações alérgicas em individuos susceptíveis, quando ingeridos com alimentos (MATSUMOTO e col. 1996, BLANCO e col. 1997, SANCHEZ-BORGES e col. 1997, OLSEN 1998a), além de serem agentes diretos ou transmissores de doenças (BAGGIO sd).

Embora seja dificil estabelecer relação entre alimentos contendo matérias estranhas e transmissão de doenças, devido à escassez de relatos, os insetos e os ácaros, além de poderem depositar suas dejeções sobre os alimentos, causando doenças por fungos, bactérias, virus, protozoários e helmintos (GORHAN 1979, STASNY 1981), também podem contaminar os produtos pela deposição de germes que se encontram aderidos ao corpo e patas (VASQUEZ 1977cd, GORHAN 1993, FEHLHABER e JANETSCHKE 1992).

Entre os insetos, as moscas têm papel importante na contaminação de alimentos. Assim, OLSEN (1998b) considerou 21 espécies de moscas (entre as 120.000 classificadas taxonomicamente) como potencialmente prejudiciais à saúde humana, por serem vetores passivos de patógenos causadores de enfermidades transmitidas por alimentos, como Shigella, Salmonella, Escherichia coli, Campylobacter jejuni e Vibrio cholera.

Outra matéria estranha de origem biológica que pode ser encontrada em alimentos são os pêlos. A detecção destes pode indicar contato do produto com mamiferos ou com excrementos e/ou urina destes animais. Entre os mamíferos, alguns têm por hábito lamber-se, ocasião na qual engolem os pêlos que, por não 
serem digeridos no sistema digestivo, são eliminados nos excrementos; assim, o achado de pêlos no alimento, pode indicar a presença de bactérias fecais, contaminando-o (STASNY 1981, VASQUEZ 1961, 1981).

De acordo com CARVALHO NETO (1987) os roedores, além de consumirem gêneros alimentícios, provocando danos e perdas em todas as fases de produção, processamento e estocagem, ainda os contaminam com seus pêlos. São êles, também, transmissores, em potencial, de uma série de doenças, entre elas a leptospirose, infecção comum em ratos e camundongos causada por diversos sorotipos de Leptospira interrogans, e a salmonelose, que causa gastroenterite aguda grave, quando há contato do alimento com o rato de esgoto (Ratus norvegicus) e seus excrementos contaminados com Salmonella sp. Viroses também podem ser transmitidas ao homem por roedores, pela contaminação do alimento com excrementos ou urina contendo virus (LARKIN 1981).

Os pássaros também podem contaminar os alimentos por serem vetores, hospedeiros ou transportadores passivos de vários patógenos e parasitas; ácaros e piolhos podem estar presentes nas bárbulas das penas que se soltam e podem cair no produto; além de Salmonella que, presente no trato digestivo da ave, contamina o alimento através dos excrementos (JACKSON 1991, TROLLER 1993, DECKER 1994).

Insetos, como moscas e baratas, assim como ratos, camundongos e pássaros, devem ser considerados como fatores de risco quando presentes em locais de manipulação de alimentos e o seu controle e eliminação deve ser realizado, através do emprego de Boas Práticas de Fabricação (OLSEN 1998b).

Assim, para que não ocorra deterioiação dos alimentos, principalmente "in natura", durante o armazenamento, é preciso utilizar práticas adequadas de manuseio, visando todos os possíveis contaminantes, como bactérias, fungos, insetos e ácaros, além de roedores e pássaros. Quando presentes, os insetos, ao atacarem o alimento, facilitam a entrada de bactérias e fungos e de invasores secundários, como outros insetos e ácaros. Roedores e pássaros, como primeiro nível de consumidores, além de se alimentarem do produto, os contaminam com excrementos, pêlos e penas, propiciando, também, o aparecimento de consumidores de terceiro nível, como outros insetos e ácaros micófagos. Também os excrementos dos consumidores de primeiro nível são utilizados como substrato para o crescimento microbiano e como alimento para alguns consumidores de segundo e terceiro nivel (SINHA 1991). 
A elaboração de sucos e polpas de frutas que serão utilizados para a elaboração de geléias e de doces em pasta, envolve várias etapas, desde a recepção da matéria-prima, seleção, lavagem e desintegração das frutas, até o enchimento da embalagem e esterilização do produto acabado (JACKIX 1988); o mesmo acontece na elaboração de frutas em calda. Quando não são observados procedimentos de Boas Práticas de Fabricação (BPF), matérias estranhas poderão estar presentes nesses derivados de frutas, por utilização de matéria-prima contaminada ou por sua incorporação durante a industrialização.

Ao contrário do que ocorre com a detecção de filamentos micelianos em produtos de frutas, que ao longo dos anos têm sido alvo de pesquisas para aprimoramento da metodologia analítica, os métodos para o estudo de matérias estranhas têm-se mantido inalterados.

Publicações sobre matérias estranhas em produtos de frutas são encontradas em pequeno número, referindo-se, quase sempre, apenas à metodologia analítica, como as descritas na Association of Official Analytical Chemists International (BOESE e CICHOWICZ 1995) e no Macroanalytical Procedures Manual (CENTER FOR FOOD SAFETY AND APPLIED NUTRITION 1984).

WHEELER (1964) propôs um método para o isolamento de matérias estranhas em pasta de fruta, utilizando peneiração e flutuação. Por sua vez, KVENBERG e col. (1975) publicaram estudo colaborativo no qual descrevem um método alternativo ao proposto por WHEELER (1964), adicionando etapas que visam facilitar o isolamento de matérias estranhas em figo e em pasta de fruta.

$\mathrm{Na}$ década seguinte, BARBIERI (1987) publicou manual técnico contendo métodos para deteç̧ão de matérias estıanhas em alimentos, entre os quais encontram-se alguns produtos de frutas.

SANTOS e col. (1990) propuseram métodos para isolamento de matérias estranhas em sucos de maracujá, tamarindo e uva, além de analisarem amostras industrializadas desses produtos, encontrando nos sucos de maracujá e uva somente fragmentos de insetos e em número inferior a 20; já no de tamarindo foram detectados, além de fragmentos de insetos em número elevado, larvas e ovos de insetos.

BERBARI e col. (1992), em estudo sobre frutas cristalizadas, cita a importância do processamento adequado deste produto para serem evitadas contaminações por insetos, roedores e microrganismos. 


\section{OBJETIVOS}

- Utilizar procedimentos analíticos existentes ou adaptá-los, quando necessário, com a finalidade de:

- quantificar filamentos micelianos pelo método Howard;

- quantificar filamentos micelianos de Geotrichum e

- isolar e quantificar matérias estranhas,

na microscopia alimentar de geléias de frutas, doces de frutas em pasta e frutas em calda.

- Verificar as condições higiênicas de geléias de frutas, doces de frutas em pasta e frutas em calda industrializados, comercializados em supermercados da Cidade de São Paulo, quanto aos parâmetros citados. 


\section{MATERIAL E METODOLOGIA}

\subsection{MATERIAL}

$\mathrm{Na}$ presente pesquisa foram estudados as geléias de frutas, os doces de frutas em pasta e as frutas em calda, de diferentes marcas e tipos de frutas, envasadas no País, com registro no Ministério da Saúde e comercializados nas principais redes de supermercados da Cidade de São Paulo.

\subsection{AMOSTRAGEM}

Foi realizado um levantamento das marcas e das diferentes frutas dos três tipos de produtos a serem estudados: geléias, doces em pasta e frutas em calda, comercializadas nas principais redes de supermercados da Cidade de São Paulo. Este levantamento foi complementado com informações colhidas junto às empresas produtoras, quanto aos tipos de frutas dos três tipos de produtos relacionados para o estudo.

A partir desse levantamento foi planejado o número de amostras que seriam colhidas para as análises de verificação das condições higiênicas, o que foi determinado pelo equacionamento de dois fatores:

- a capacidade disponível para o processamento laboratorial $\mathrm{e}$

- a necessidade de se atingir quantidade compativel com a análise estatística dos resultados.

Para a padronização das metodologias, o número de amostras-teste foi estabelecido levando-se em consideração o número de marcas comercializadas para cada tipo de produto e fruta e a variabilidade, dentro de cada tipo de produto, quanto aos ingredientes. 


\subsubsection{Amostras de geléias de frutas, doces de frutas em pasta e frutas em calda para verificação das condições higiênicas}

Foram colhidas, em supermercados da Cidade de São Paulo, pertencentes à oito principais redes de hiper e supermercados, no período de abril/98 à janeiro/99, 117 amostras de geléias de frutas, 57 de doces de frutas em pasta e 114 de frutas em calda, correspondentes a 3 colheitas de amostras, de mesma marca e com número de lote/datas de fabricação e/ou validade diferentes em cada colheita (Tabela 1).

Tabela 1. Amostras para verificação das condições higiênicas dos produtos estudados. São Paulo, 1998/99.

\begin{tabular}{|c|c|c|c|c|c|c|c|c|}
\hline $\begin{array}{l}\text { Geléias de } \\
\text { frutas }\end{array}$ & $\begin{array}{l}\mathrm{N}^{\circ} \text { de } \\
\text { marcas }\end{array}$ & $\begin{array}{c}\mathrm{N}^{\circ} \text { de } \\
\text { amostras }\end{array}$ & $\begin{array}{c}\text { Doces de } \\
\text { frutas em } \\
\text { pasta }\end{array}$ & $\begin{array}{l}\mathrm{N}^{\circ} \text { de } \\
\text { marcas }\end{array}$ & $\begin{array}{c}\mathrm{N}^{\circ} \text { de } \\
\text { amostras }\end{array}$ & $\begin{array}{l}\text { Frutas em } \\
\text { calda }\end{array}$ & $\begin{array}{l}\mathrm{N}^{\circ} \mathrm{de} \\
\text { marcas }\end{array}$ & $\begin{array}{c}\mathrm{N}^{\circ} \mathrm{de} \\
\text { amostras }\end{array}$ \\
\hline Abacaxi & 2 & 6 & Bananada & 2 & 6 & Abacaxi & 7 & 21 \\
\hline Ameixa & 2 & 6 & Goiabada & 12 & 36 & Ameixa & 7 & 21 \\
\hline Amora & 4 & 12 & Marmelada & 5 & 15 & Figo & 7 & 21 \\
\hline Damasco & 2 & 6 & & & & Goiaba & 4 & 12 \\
\hline Figo & 1 & 3 & & & & Pêssego & 9 & 27 \\
\hline Framboesa & 3 & 9 & & & & $\begin{array}{l}\text { Salada de } \\
\text { frutas }\end{array}$ & 4 & 12 \\
\hline Goiaba & 8 & 24 & & & & & & \\
\hline Morango & 9 & 27 & & & & & & \\
\hline Pêssego & 2 & 6 & & & & & & \\
\hline Uva & 6 & 18 & & & & & & \\
\hline Total & & 117 & & & 57 & & & 114 \\
\hline
\end{tabular}

No planejamento amostral ficou estabelecido que seriam colhidas amostras de todas as marcas nacionais disponiveis no mercado, porém, por diferir o número de indústrias que fabricam um mesmo tipo de produto, não foi possível colher igual número de amostras para todos.

Para cada amostra de frutas em calda foram colhidas 2 unidades (embalagens) de mesmo lote/prazo de validade, assim como para algumas geléias cuja embalagem não apresentava quantidade suficiente para as 3 determinações analiticas e em duplicata (método Howard, contagem de filamentos micelianos de Geotrichum e 
determinação de matérias estranhas). Inversamente, para doces de fruta em pasta foi colhida apenas uma unidade por amostra pelo fato das embalagens terem quantidade suficiente para as 3 determinações.

\subsubsection{Amostras-teste de geléias de frutas, doces de frutas em pasta e frutas em calda para a padronização da metodologia}

Foram adquiridas 40 amostras de geléias de frutas e 12 de doces de frutas em pasta (sendo 4 amostras de cada tipo de produto/fruta), além de 12 amostras de frutas em calda ( 2 de cada tipo de fruta), conforme indicado na Tabela 2.

Tabela 2. Amostras-teste para padronização/adaptação de procedimentos analíticos. São Paulo, 1998/99.

\begin{tabular}{|c|c|c|c|c|c|c|c|c|}
\hline $\begin{array}{l}\text { Geléias de } \\
\text { frutas }\end{array}$ & $\begin{array}{l}\mathrm{N}^{\circ} \text { de } \\
\text { marcas }\end{array}$ & $\begin{array}{c}\mathrm{N}^{\circ} \text { de } \\
\text { amostras }\end{array}$ & $\begin{array}{c}\text { Doces de } \\
\text { frutas em } \\
\text { pasta }\end{array}$ & $\begin{array}{l}\mathrm{N}^{\circ} \text { de } \\
\text { marcas }\end{array}$ & $\begin{array}{c}\mathrm{N}^{\circ} \mathrm{de} \\
\text { amostras }\end{array}$ & $\begin{array}{l}\text { Frutas em } \\
\text { calda }\end{array}$ & $\begin{array}{l}\mathrm{N}^{\circ} \text { de } \\
\text { marcas }\end{array}$ & $\begin{array}{c}\mathrm{N}^{\circ} \text { de } \\
\text { amostras }\end{array}$ \\
\hline Abacaxi & 2 & 4 & Bananada & 2 & 4 & Abacaxi & 7 & 2 \\
\hline Ameixa & 2 & 4 & Goiabada & 12 & 4 & Ameixa & 7 & 2 \\
\hline Amora & 4 & 4 & Marmelada & 5 & 4 & Figo & 7 & 2 \\
\hline Damasco & 2 & 4 & & & & Goiaba & 4 & 2 \\
\hline Figo & 1 & 4 & & & & Pêssego & 9 & 2 \\
\hline Framboesa & 3 & 4 & & & & $\begin{array}{l}\text { Salada de } \\
\text { frutas }\end{array}$ & 4 & 2 \\
\hline Goiaba & 8 & 4 & & & & & & \\
\hline Morango & 9 & 4 & & & & & & \\
\hline Pêssego & 2 & 4 & & & & & & \\
\hline Uva & 6 & 4 & & & & & & \\
\hline Total & & 40 & & & 12 & & & 12 \\
\hline
\end{tabular}

Para a padronização da diluição das amostras de geléias de frutas e doces de frutas em pasta, para o método Howard, foi estabelecido que seriam colhidas 4 amostras para cada tipo de fruta, tanto para geléias como para doces em pasta, por serem produtos que não apresentam grande variabilidade, uma vez que, a proporção 
entre ingredientes vegetais (polpa da fruta) e os demais componentes que deve conter o produto é estabelecido pela legislação de alimentos em vigor (BRASIL 1978a, SÃO PAULO 1978).

Para proceder à adaptação dos métodos Howard, de contagem de filamentos micelianos de Geotrichum e de determinação de matérias estranhas em frutas em calda, foi estabelecido que seriam colhidas 2 amostras para cada tipo de fruta, em razão da pequena variabilidade entre os tipos de produtos, quanto aos ingredientes do produto final (apenas fruta e calda).

\subsection{PROCEDIMENTOS ANALÍTICOS}

\section{A. MÉTOdo HOWARD PARA CONTAGEM DE FILAMENTOS MICELIANOS}

\subsubsection{Padronização da diluição para as amostras-teste de geléias de frutas e doces de frutas em pasta}

\section{. Geléias de frutas}

A padronização da diluição foi realizada levando-se em consideração o teor de sólidos solúveis da amostra ou grau Brix ( $\left.{ }^{\circ} \mathrm{Brix}\right)$, medido em refratômetro, baseando-se nas diluições das frutas descritas no método 16.18.05/982.33B da Association of Official Analytical Chemists International (AOAC International) (BOESE e CICHOWICZ 1995, p.63).

Foram analisadas, inicialmente, geléias cujas frutas têm diluição padronizada no procedimento analítico citado acima, ou seja: damasco e pêssego $(1+1)$; goiaba $(1+3)$; amora, framboesa e morango (1+6). Após a diluição do sedimento com 
solução a $0,5 \%$ de carboximetilcelulose, mediu-se o ${ }^{\circ}$ Brix em refratômetro (Fluxograma 1 - Anexos).

Para estabelecer a diluição a ser usada para as geléias de abacaxi, ameixa, figo e uva, que não têm diluição descrita no método 16.18.05/982.33B, seguiu-se o mesmo procedimento do Fluxograma 1 (Anexos). Testaram-se diferentes diluições do sedimento obtido após a centrifugação das amostras-teste com solução a $0,5 \%$ de carboximetilcelulose, buscando valores em intervalo semelhante àquele das frutas padronizadas na metodologia da AOAC International.

\section{. Doces de frutas em pasta}

Para as amostras-teste de goiabada, bananada e marmelada, seguiu-se o mesmo procedimento estabelecido para as geléias de frutas, testando-se diferentes diluições da amostra com solução de carboximetilcelulose, até a obtenção de valores em intervalo semelhante àquele das frutas padronizadas no método $16.18 .05 / 982.33 \mathrm{~B}$ da AOAC International.

\subsubsection{Adaptação do método Howard para frutas em calda}

As amostras-teste de frutas em calda foram preparadas de acordo com os métodos da AOAC International 16.18.03/970.75, para sucos enlatados de citros e de abacaxi, e 16.17.01/984.29ABC, para contagem Howard, (BOESE e CICHOWICZ 1995 , p.62 e 60-1, respectivamente), recomendados no procedimento $9 \mathrm{~L} 4 \mathrm{~b}$ do Macroanalytical Procedures Manual (CENTER FOR FOOD SAFETY AND APPLIED NUTRITION 1984) para determinação de fungos em produtos de abacaxi em pedaços, os quais foram adaptados para os produtos de frutas em calda, com as seguintes modificações (Fluxograma 2 - Anexos):

- inicialmente pesar a amostra (fruta + calda) para obter o peso líquido;

- transferir $50 \mathrm{~mL}$ da calda para tubo de centrífuga, antes de peneirar a amostra;

- eliminar a etapa de adição de $\mathrm{HCl}$ ao material centrifugado. 


\subsubsection{Contagem de filamentos micelianos, pelo método Howard, em geléias de frutas, doces de frutas em pasta e frutas em calda}

\subsubsection{Preparo das amostras}

\section{. Geléias de frutas e doces de frutas em pasta}

O preparo das amostras de geléias de frutas e de doces de frutas em pasta, foi realizado segundo o método 16.18.05/982.33 AdB da AOAC International (BOESE e CICHOWICZ 1995, p. 63), em duplicata, com 50g cada (Fluxogramas 3 e 4 Anexos).

Foram utilizadas as diluições padronizadas pela $\mathrm{AOAC}$ e as propostas neste estudo, segndęarara pềssego e damasco, 1+1; goiaba, 1+3; amora, framboesa, morango, abacaxi, ameixa, figo e uva, $1+6$;

. doces de frutas em pasta: goiaba, banana e marmelo, $1+4$.

\section{. Frutas em calda}

As amostras de frutas em calda foram analisadas segundo os métodos descritos no item 4.3.2, com adaptação de metodologia, em duplicata (duas embalagens de mesmo lote/datas de fabricação e/ou validade), conforme o Fluxograma 2 (Anexos).

\subsubsection{Preparo das câmaras e contagem de filamentos micelianos}

Para os 3 tipos de produtos o preparo das câmaras para contagem de filamentos micelianos foi realizado segundo o método 16.17.01/984.29B da AOAC International (BOESE e CICHOWICZ 1995, p. 60) 
Colocou-se, com espátula, quantidade adequada do sedimento diluído e homogeneizado, no centro da câmara de Howard e cobriu-se com lamínula, sendo preparadas três câmaras para cada duplicata.

Foi utilizada câmara de Howard com plataforma circular de $19 \mathrm{~mm}$ de diâmetro e profundidade de $0,1 \mathrm{~mm}$ e lamínula contendo, gravados, 25 círculos com $1,382 \mathrm{~mm}$ de diâmetro cada um.

Para medir as hifas de fungos foi colocado, na ocular do microscópio, um disco micrométrico contendo, gravados, quadrados cujos lados medem 1/6 do campo microscópico.

A contagem dos filamentos foi realizada em microscópio óptico, com aumento de 100x. Foram considerados como positivos os campos que apresentavam uma ou mais hifas, com tamanho igual ou maior a 1/6 do campo microscópico, ou quando a soma dos comprimentos das hifas presentes no campo fosse igual ou maior a $1 / 6$.

Para cada duplicata foram contados 75 campos ( 3 montagens com 25 campos cada uma).

\subsubsection{Características morfológicas das hifas de fungos}

As hifas de fungos quando observadas ao microscópio óptico, com aumento de 100 a 450x, apresentam as seguintes características morfológicas:

- paredes paralelas: as hifas têm aspecto tubular e muitas vezes o diâmetro do filamento é uniforme em todo o comprimento, de modo que, ao microscópio, elas são vistas como linhas paralelas; alguns fungos podem apresentar a parede dupla ou com saliências, não apresentando paralelismo;

- septos: muitos fungos apresentam septos, que dividem as hifas em segmentos;

- granulações: em muitos fungos o protoplasma da parede das hifas apresentase com aspecto granular; em alguns fungos mais finos a granulação não é visivel;

- ramificações: os fungos apresentam ramificações que facilitam o reconhecimento da hifa; nos fragmentos menores elas não são observadas;

. extremidades: normalmente são abruptas; 
. aparência não refringente: as hifas são pouco refringentes à luz.

\subsubsection{Cálculo do número de filamentos micelianos}

$$
\mathrm{N}=\underline{\mathrm{n}^{\circ} \text { de campos positivos } \times 100}
$$

75

onde: $\mathrm{N}=$ percentual de campos positivos para filamentos micelianos

\section{B. MÉTODO PARA CONTAGEM DE FILAMENTOS MICELIANOS DE Geotrichum}

\subsubsection{Adaptação do método de contagem de filamentos micelianos de Geotrichum para frutas em calda}

As amostras-teste de frutas em calda foram analisadas segundo os métodos da AOAC International 16.19.12/974.34a de fungos em vegetais, frutas e sucos enlatados e 16.19.09/984.30 de contagem de fungo Geotrichum, (BOESE e CICHOWICZ 1995, p.66 e 65 respectivamente) que foram adaptados para as frutas em calda, com as seguintes modificações (Fluxograma 2 - Anexos):

- após drenar a amostra na peneira $n^{0} 8$ sobre recipiente de vidro, não descartá-la; lavar a amostra e a peneira com cerca de $300 \mathrm{~mL}$ de água filtrada;

. fazer a transferência do líquido do recipiente de vidro, para as duas peneiras concomitantemente, colocando a peneira $\mathrm{n}^{\circ} 16$ sobre a de $\mathrm{n}^{\circ} 230$, ambas de $12,7 \mathrm{~cm}$ ( 5 polegadas) de diâmetro;

- retornar a peneira com a amostra para o recipiente de vidro. 


\subsubsection{Contagem de filamentos micelianos de Geotrichum em geléias de frutas, doces de frutas em pasta e frutas em calda}

\subsubsection{Preparo das amostras}

\section{. Geléias de frutas e doces de frutas em pasta}

As amostras de geléias de frutas e de doces de frutas em pasta foram preparadas segundo $o$ procedimento descrito na AOAC International 16.19.13/982.34 AdB (BOESE e CICHOWICZ 1995, p.67), em duplicata, com 50 g cada (Fluxogramas 3 e 4 - Anexos).

\section{. Frutas em calda}

O preparo das amostras de frutas em calda foi realizado segundo o método 16.19.12/974.34 da AOAC International (BOESE e CICHOWICZ 1995, p.66), com adaptação de metodologia, em duplicata (duas embalagens de mesmo lote/datas de fabricação e/ou validade) (Fluxograma 2 - Anexos).

\subsubsection{Preparo das lâminas para contagem de filamentos micelianos de Geotrichum}

Para os 3 tipos de produtos o preparo das lâminas para contagem de filamentos micelianos foi realizado segundo o método 16.19.09/984.30B da AOAC International (BOESE e CICHOWICZ 1995, p. 65).

Foi colocado $0,5 \mathrm{~mL}$ do sedimento diluído e homogeneizado no centro de uma lâmina, com pipeta de $1 \mathrm{~mL}$ (cortada na marca $0,9 \mathrm{~mL}$, para obter um diàmetro maior na ponta da pipeta); esse material foi espalhado e coberto com a lamínula, sendo preparadas 2 lâminas para cada duplicata. 
Utilizou-se lâmina de vidro, com dimensões de $55 \times 100 \times 2 \mathrm{~mm}$, contendo linhas verticais paralelas distantes $5 \mathrm{~mm}$ umas das outras e lamínula também de vidro, com $50 \times 85 \times 2 \mathrm{~mm}$. Os filamentos micelianos foram contados em microscópio estereoscópico, com luz transmitida e aumento de 30 a 45x.

\subsubsection{Características morfológicas das hifas de Geotrichum}

As hifas de Geotrichum. quando observadas ao microscópio óptico, com aumento de 100 a $400 \mathrm{x}$, apresentam, além das características comuns aos outros fungos, como aspecto tubular, presença de granulações e aparência não refringente, as seguintes (BOESE e CICHOWICZ, 1995, p.65):

. septos: as hifas de Geotrichum são septadas;

- espessura: as hifas tendem a diminuir a espessura gradualmente em direção à extremidade;

- ramificações: apresentam ramificações regulares e em $45^{\circ}$, dando a aparência de uma pena.

$\mathrm{Na}$ contagem dos filamentos, ao microscópio estereoscópico, devem ser contados aqueles com 3 ou mais ramificações características de Geotrichum.

\subsubsection{Cálculo do número de filamentos de Geotrichum}

\section{- Geléias de frutas e doces de frutas em pasta}

$$
\mathrm{N}=\mathrm{S} \times 100
$$

onde:

$\mathrm{N}=$ número de filamentos micelianos $/ 100 \mathrm{~mL}$ de preparação

$\mathrm{S}=$ total dos filamentos micelianos contados nas 2 lâminas

$\mathrm{O}$ resultado foi expresso como a média aritmética dos valores encontrados nas duplicatas. 


\section{- Frutas em calda}

$$
N=\frac{S \times 100 \times V}{V_{1} \times P}
$$

onde:

$\mathrm{N}=$ número de filamentos micelianos $/ 100 \mathrm{~g}$ de amostra

$\mathrm{S}=$ total dos filamentos micelianos contados nas 2 lâminas

$\mathrm{V}=$ volume após diluição com carboximetilcelulose

$\mathrm{V}_{1}=$ volume de amostra colocado nas 2 lâminas $(1 \mathrm{~mL})$

$\mathrm{P}=$ peso líquido da amostra

$O$ resultado foi expresso como a média aritmética dos valores encontrados nas duplicatas.

\section{MÉTODO PARA DETERMINAÇÃO DE MATÉRIAS ESTRANHAS}

\subsubsection{Adaptação de métodos para doces de frutas em pasta e frutas em calda}

\section{. Doces de frutas em pasta}

O método da AOAC International 16.10.06/950.89a (BOESE e CICHOWICZ 1995, p. 29) para geléias de frutas foi utilizado, também, para a análise das amostras de doces de frutas em pasta, com a seguinte adaptação de metodologia: após a pesagem da amostra no frasco armadilha, ao se adicionar a água filtrada a $50^{\circ} \mathrm{C}$, deve-se aquecer em banho-maria até dispersão dessa amostra (Fluxograma 4 Anexos). 


\section{. Frutas em calda}

As amostras-teste de frutas em calda foram analisadas segundo os métodos 9L4a e 9L7a, descritos no Macroanalytical Procedures Manual (CENTER FOR FOOD SAFETY AND APPLIED NUTRITION 1984) para determinação de matérias estranhas em produtos de abacaxi. Estes métodos foram aqui adaptados para os seis produtos de frutas em calda, com as seguintes modificações (Fluxograma 2 Anexos):

- iniciar o procedimento com a amostra na peneira $n^{0} 8$ colocada sobre o recipiente de vidro, reservado no método de contagem de filamentos de Geotrichum;

- substituir a peneira $n^{\circ} 14$ pela de $n^{\circ} 16$ e a de $n^{\circ} 140$ pela de 230 ;

. substituir o frasco armadilha de $2.000 \mathrm{~mL}$ por um de $1.000 \mathrm{~mL}$;

- realizar duas extrações com óleo mineral;

- acrescentar uma etapa de filtração do material do tubo de centrifuga utilizado no método de contagem de filamentos micelianos de Geotrichum.

\subsubsection{Determinação de matérias estranhas em geléias de frutas, doces de frutas em pasta e frutas em calda}

\subsubsection{Isolamento de matérias estranhas}

\section{. Geléias de frutas}

As amostras de geléias de frutas foram analisadas segundo o método da AOAC International 16.10.06/950.89a (BOESE e CICHOWICZ 1995, p. 29), em duplicata, com $100 \mathrm{~g}$ cada (Fluxograma 3 - Anexos).

\section{. Doces de frutas em pasta}

Para os doces de frutas em pasta foi utilizado o método da AOAC International 16.10.06/950.89a (BOESE e CICHOWICZ 1995, p.29), com adaptação de metodologia, em duplicata, com $100 \mathrm{~g}$ cada (Fluxograma 4 - Anexos). 


\section{. Frutas em calda}

As amostras foram analisadas segundo o procedimento descrito nos métodos 9L4a e 9L7a do Macroanalytical Procedures Manual (CENTER FOR FOOD SAFETY AND APPLIED NUTRITION 1984), com adaptação de metodologia, em duplicata (duas embalagens de mesmo lote/datas de fabricação e/ou validade) (Fluxograma 2 - Anexos).

\subsubsection{Identificação e contagem de matérias estranhas}

As matérias estranhas presentes no papel de filtro foram identificadas e quantificadas ao microscópio estereoscópico com aumento de $30 \mathrm{x}$ e, quando necessário, ao microscópio óptico com aumento de 250x.

Para a classificação taxonômica, as matérias estranhas de natureza biológica foram retiradas do papel de filtro e montadas em lâminas de microscópio, utilizandose líquido clarificante de Hoyers (VASQUEZ 1977a); foram cobertas com lamínulas e mantidas em estufa a $40^{\circ} \mathrm{C}$, por cerca de 4 dias, para secagem e diafanização. Para a sua identificação e classificação foram utilizados os seguintes parâmetros:

Insetos: com base nas características morfológicas foram identificados e classificados (quando possivel) quanto a ordem, familia ou gênero (VASQUEZ 1977b, BORROR 1988, GORHAN 1987, INSECTS of AUSTRALIA 1990),

Fragmentos de insetos: foram identificados de acordo com VASQUEZ (1977a), sem classificá-los quanto a taxonomia.

Ácaros: foram identificados de acordo com HUGHES (1976), KRANTZ (1978), GORHAN (1987) e por comparação com lâminas da coleção do Laboratório de Microscopia Alimentar do Instituto Adolfo Lutz.

Pêlos animais: a identificação do tipo de pêlo baseou-se na observação da raiz, cutícula, córtex e medula (VASQUEZ 1961, 1977d, 1981) e por comparação com lâminas da coleção do Laboratório de Microscopia Alimentar do Instituto Adolfo Lutz. 


\subsection{FOTOMICROGRAFIAS}

As fotomicrografias das hifas de fungos foram tiradas de lâminas a fresco das amostras em estudo, em microscópio estereoscópico com luz transmitida e em microscópio óptico.

As matérias estranhas de natureza biológica foram fotografadas das lâminas permanentes elaboradas de acordo com o exposto no ítem 4.3.7.2, em microscópios óptico e estereoscópico.

\subsection{ANÁLISE ESTATÍSTICA}

Os dados obtidos após o processamento analítico das amostras, foram submetidos a tratamento estatístico, sendo apresentados sob a forma de gráficos de caixas, mais conhecidos como "boxplots", (BUSSAB e MORETTIN 1990), utilizando-se o programa estatistico MINITAB for Windows versão 11 e tabelas e gráficos de barras empregando-se o programa Excel for Windows.

Nos "boxplots" foram representados os valores de: mínimo, primeiro quartil (Q1), mediana, terceiro quartil (Q3) e máximo.

O valor que limita o primeiro quartil (Q1) é aquele abaixo do qual, após ordenação dos dados, seriam encontrados os primeiros $25 \%$ dos resultados; a mediana é o valor que divide os dados em duas partes ( $50 \%$ dos resultados); o terceiro quartil (Q3) é o valor limite acima do qual estão os demais $25 \%$ dos resultados.

Também estão indicados, nos "boxplots", os valores aberrantes, que são os valores superiores àqueles considerados como máximos para um determinado conjunto de dados, e que foram calculados de acordo com a fórmula Q3+1,5(Q3-Q1).

\subsection{LOCAL DAS ANÁLISES}

Os procedimentos analíticos foram realizados na Seção de Microscopia Alimentar do Instituto Adolfo Lutz/SP. 


\section{RESULTADOS E DISCUSSÃO}

\section{A. CONTAGEM DE FILAMENTOS MICElanos PELO MÉTOdo HOWARD}

\subsection{GELÉIAS DE FRUTAS}

\subsubsection{Padronização da diluição das amostras-teste para contagem Howard}

No método 16.18.05/982.33B da AOAC International (BOESE e CICHOWICZ 1995, p.63) para contagem Howard em geléias de frutas, são estabelecidas diluições para damasco e pêssego $(1+1)$, goiaba $(1+3)$, amora, framboesa e morango $(1+6)$, mas não especifica qual o parâmetro utilizado para definir essas diluições. Como neste estudo, além daquelas, também seriam analisadas amostras de geléias de abacaxi, ameixa, figo e uva, foi necessário padronizar as diluições para estas frutas.

Testes iniciais com geléias das frutas padronizadas no método citado, utilizando como parâmetro o volume do sedimento obtido após a centrifugação da amostra (Fluxograma 1 - Anexos), apresentaram uma relação inversamente proporcional entre a diluição estabelecida e o volume do sedimento, ou seja, as frutas com menor diluição continham maior volume (goiaba, damasco e pêssego, média de $7 \mathrm{~mL}$ ) enquanto aquelas com maior diluição deram menor volume (amora, framboesa e morango, média de $3 \mathrm{~mL}$ ).

Foi testado o parâmetro teor de sólidos solúveis ( $\left.{ }^{\circ} \mathrm{Brix}\right)$ que é utilizado para contagem Howard em produtos de tomate (método 16.19.02/965.41 da AOAC International, BOESE e CICHOWICZ 1995, p.63), que mostrou-se adequado tanto para as geléias de frutas como para os doces de frutas em pasta (item 5.2.1).

Os resultados obtidos nos testes para padronização da diluição do sedimento após a centrifugação da amostra, são apresentados na Tabela 3 e representam a média aritmética dos valores de ${ }^{\circ}$ Brix encontrados nas 4 amostras-teste de cada tipo de geléia de fruta. 
Tabela 3. Diluição e ${ }^{\circ}$ Brix das amostras-teste de geléias de frutas. São Paulo, 1998/99.

\begin{tabular}{lccc}
\hline $\begin{array}{c}\text { Tipos de geléias de } \\
\text { frutas }\end{array}$ & $\begin{array}{c}\mathrm{N}^{\circ} \text { de } \\
\text { amostras }\end{array}$ & Diluição & ${ }^{\circ}$ Brix \\
\hline Amora & 4 & $1+6$ & 3,3 \\
Damasco & 4 & $1+1$ & $9,6 *$ \\
Framboesa & 4 & $1+6$ & 3,3 \\
Goiaba & 4 & $1+3$ & 4,0 \\
Morango & 4 & $1+6$ & 3,4 \\
Pêssego & 4 & $1+1$ & $9,8 *$ \\
Abacaxi & 4 & $1+6$ & 3,1 \\
Ameixa & 4 & $1+6$ & 3,6 \\
Figo & 4 & $1+6$ & 3,9 \\
Uva & 4 & $1+6$ & 3,4 \\
\hline
\end{tabular}

* = Para o cálculo do percentual de filamentos de fungos o resultado da contagem deve ser dividido por 2 (BOESE e CICHOWICZ 1995, p.63).

As amostras-teste de geléias de amora, framboesa, goiaba e morango, frutas que têm diluição estabelecida na metodologia adotada, após a diluição do sedimento, apresentaram valores de ${ }^{\circ}$ Brix entre 3,3 e 4,0 (Tabela 3).

Valores de ${ }^{\circ} \mathrm{Brix}$ 9,6 e 9,8 foram obtidos, respectivamente, para as amostrasteste de geléias de damasco e de pêssego; no entanto, pela metodologia de análise, para o cálculo do percentual de filamentos micelianos o número de campos positivos contados deve ser dividido por 2 porque, segundo CICHOWICZ (1983), essa correção da leitura faz com que os produtos de damasco e de pêssego fiquem correspondentes aos de goiaba.

Para as amostras-teste de geléias de abacaxi, ameixa, figo e uva, cuja diluição não está estabelecida, os ensaios realizados indicaram ser a diluição do sedimento na proporção $1+6$ a mais adequada, por apresentar valor de ${ }^{\circ}$ Brix entre 3,1 e 3,9 e, assim, em intervalo semelhante ao das frutas padronizadas na metodologia da AOAC (Tabela 3).

\subsubsection{Contagem de filamentos micelianos em geléias de frutas}

Os resultados individuais obtidos nas análises das 117 amostras de geléias de frutas são apresentados na Tabela 1-A (Anexos). 
$\mathrm{Na}$ Figura 1 estão representados os percentuais de amostras e os intervalos percentuais de campos positivos para filamentos micelianos dos 10 tipos de geléias de frutas estudados.

Os resultados mostram que em apenas $27 \%$ das amostras não foram observados filamentos de hifas e, embora o maior percentual de amostras positivas (38\%) pertencesse ao intervalo compreendido entre 1 e 10\% (Figura 1), houve dispersão de resultados positivos até o máximo de $83 \%$ (intervalo compreendido entre 81 e 90\%).

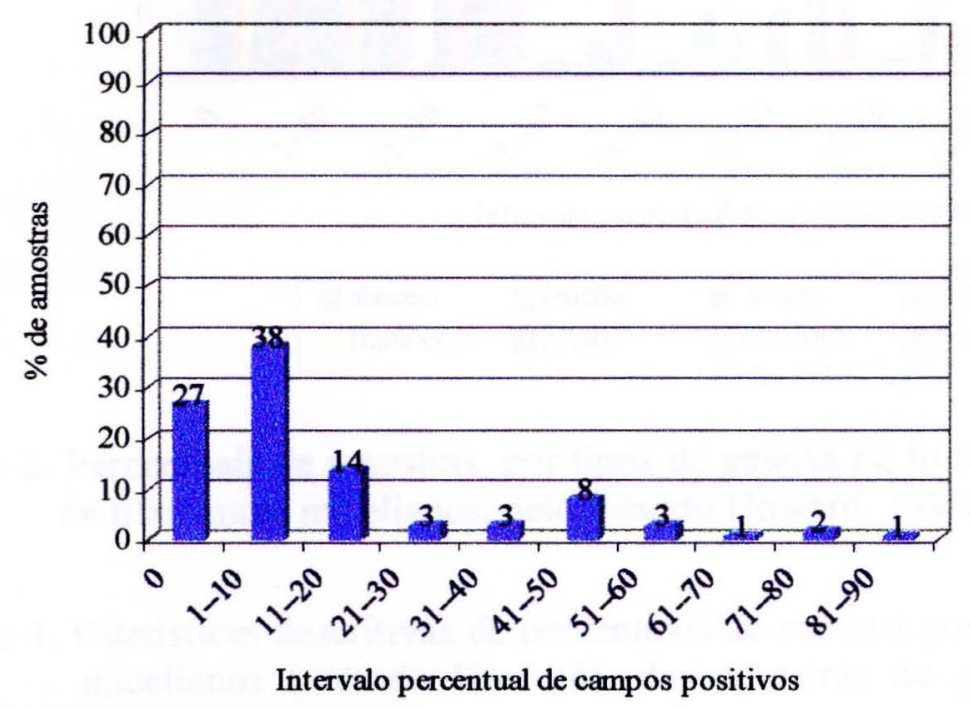

Figura 1. Percentuais de amostras de geléias de frutas quanto à contagem de filamentos micelianos, pelo método Howard. São Paulo, 1998/99.

As amostras de geléias de goiaba e de uva apresentaram percentuais de filamentos de fungos superiores às dos demais tipos, enquanto as de abacaxi, framboesa e damasco tiveram o maior percentual de amostras isentas desse contaminante (Figura 2).

Embora a média obtida de percentuais de campos positivos para fungos tenha sido $13,8 \%$ (Tabela 4), nos 10 tipos de geléias de frutas estudados encontrou-se, pelo menos, uma amostra sem filamentos de fungos (valor mínimo: zero), enquanto os valores máximos variaram entre $3 \%$ (para geléia de abacaxi) e $83 \%$ (para geléia de goiaba) (Tabela 4). 


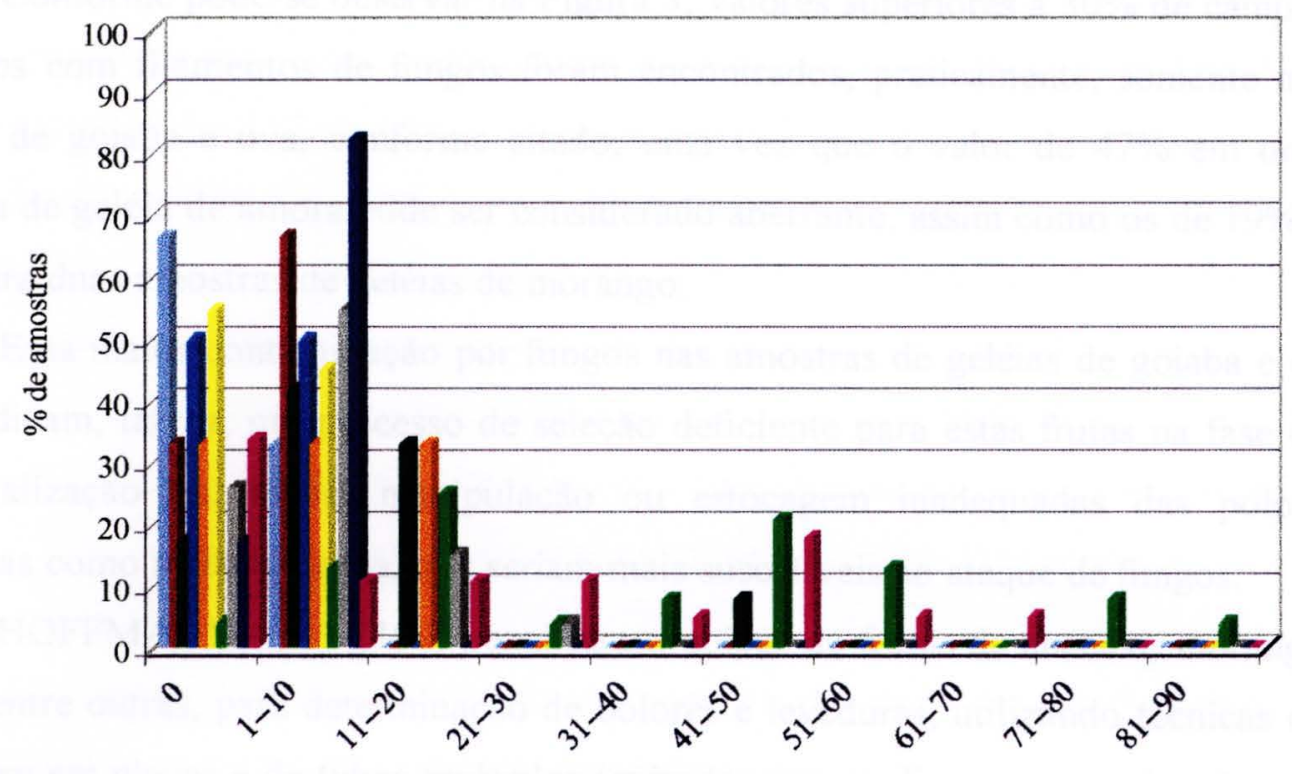

Intervalo percentual de campos positivos

\begin{tabular}{|c|c|c|c|c|}
\hline abacaxi & 돌 ameixa & amora & damasco & figo \\
\hline framboesa & goiaba & morango & pêssego & uva \\
\hline
\end{tabular}

Figura 2. Percentuais de amostras, por tipos de geléias de frutas, quanto à contagem de filamentos micelianos, pelo método Howard. 1998/99.

Tabela 4. Estatísticas descritivas de percentuais de campos positivos com filamentos micelianos (método Howard), das amostras de geléias de frutas. São Paulo, 1998/99.

\begin{tabular}{lrrrrrrr}
\hline $\begin{array}{l}\text { Tipos de geléias } \\
\text { de frutas }\end{array}$ & $\begin{array}{c}\mathrm{N}^{\circ} \text { de } \\
\text { amostras }\end{array}$ & Média & Mediana & Mínimo & Máximo & Q1 & Q3 \\
\hline Todos os tipos & 117 & 13,8 & 5,0 & 0,0 & 83,0 & 0,0 & 18,0 \\
\hline Abacaxi & 6 & 0,8 & 0,0 & 0,0 & 3,0 & 0,0 & 2,3 \\
Ameixa & 6 & 4,2 & 4,5 & 0,0 & 9,0 & 0,0 & 7,5 \\
Amora & 12 & 11,7 & 7,5 & 0,0 & 47,0 & 2,8 & 17,3 \\
Damasco & 6 & 2,0 & 1,0 & 0,0 & 6,0 & 0,0 & 4,5 \\
Figo & 3 & 6,3 & 8,0 & 0,0 & 11,0 & 0,0 & 11,0 \\
Framboesa & 9 & 1,7 & 0,0 & 0,0 & 7,0 & 0,0 & 3,0 \\
Goiaba & 24 & 35,4 & 34,0 & 0,0 & 83,0 & 13,8 & 51,5 \\
Morango & 27 & 5,4 & 3,0 & 0,0 & 25,0 & 0,0 & 7,0 \\
Pêssego & 6 & 4,3 & 4,0 & 0,0 & 8,0 & 1,5 & 8,0 \\
Uva & 18 & 21,0 & 16,5 & 0,0 & 67,0 & 0,0 & 41,0 \\
\hline Q1: primeiro quartil & & Q3: terceiro quartil & & & &
\end{tabular}


Conforme pode-se observar na Figura 3, valores superiores a 30\% de campos positivos com filamentos de fungos foram encontrados, praticamente, somente nas geléias de goiaba e uva, conforme citado, uma vez que o valor de $47 \%$ em uma amostra de geléia de amora pode ser considerado aberrante, assim como os de $19 \% \mathrm{e}$ $25 \%$ para duas amostras de geléias de morango.

Essa maior contaminação por fungos nas amostras de geléias de goiaba e de uva, indicam, talvez, um processo de seleção deficiente para estas frutas na fase de industrialização ou, ainda, manipulação ou estocagem inadequadas das polpas utilizadas como matéria-prima, que seriam mais suscetiveis ao ataque de fungos.

HOFFMANN e col. (1997) analisaram polpas de frutas de abacaxi, morango e uva, entre outras, para determinação de bolores e leveduras, utilizando técnicas de contagem em placas e de tubos múltiplos (métodos que avaliam a contaminação por fungos viáveis) e obtiveram contagens para esses contaminantes, indicando que as polpas de frutas quando utilizadas como matéria-prima para a elaboração de geléias e doces em pasta, mesmo após o processamento térmico, podem ter bolores que permaneceriam no produto final e, embora não sendo viáveis, seriam detectados na contagem de filamentos micelianos.

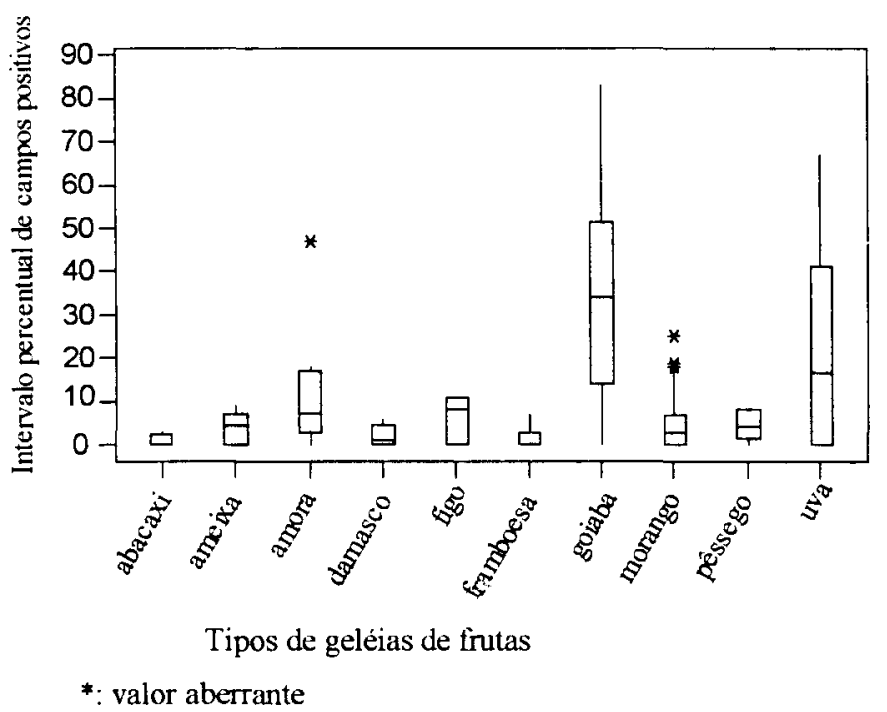

Figura 3. "Boxplot" por tipos de geléias de frutas, quanto à contagem de filamentos micelianos, pelo método Howard. São Paulo, 1998/99. 
Como a legislação de alimentos em vigor não estabelece limites de tolerância para contagem de filamentos de fungos em produtos de frutas, poder-se-ia considerar que apenas 27\% das 117 amostras analisadas, estão de acordo com a legislação.

Esses resultados indicam a necessidade de revisão da legislação bromatológica, com o estabelecimento de limites compatíveis com a realidade brasileira para o referido contaminante, como ocorre, por exemplo, nos Estados Unidos, em que o DAL - Defect Action Level (CENTER FOR FOOD SAFETY AND APPLIED NUTRITION 1989) permite para geléias de cereja e de groselha, $30 \%$ e $75 \%$, respectivamente, de campos positivos com filamentos micelianos contados pelo método Howard

Na Figura 4 é apresentada fotomicrografia de uma amostra de geléia de goiaba, onde se encontraram filamentos micelianos.

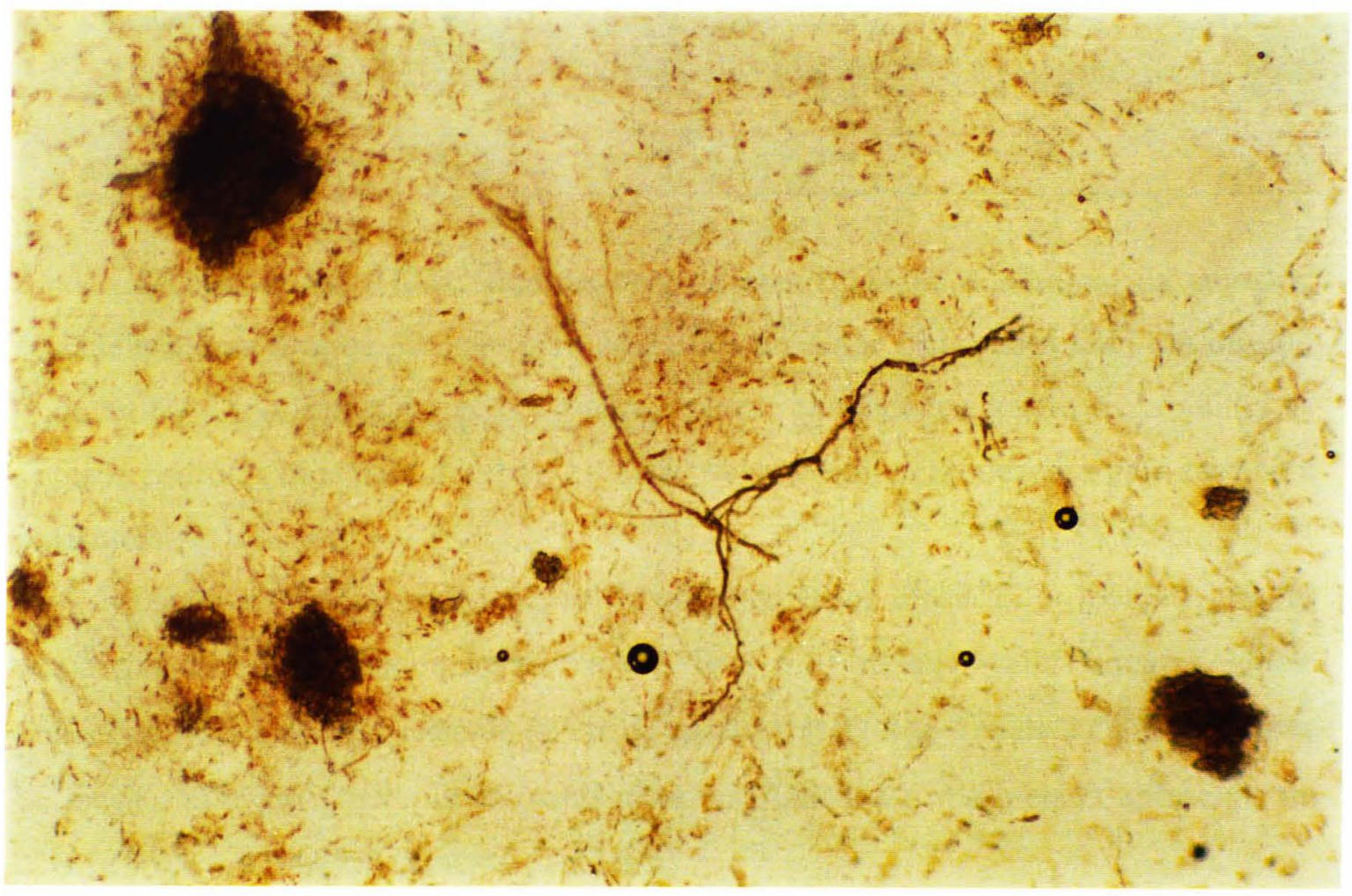

Figura 4. Filamentos micelianos encontrados em geléia de goiaba (160x). 


\subsection{DOCES DE FRUTAS EM PASTA}

\subsubsection{Padronização da diluição das amostras-teste para contagem Howard}

$\mathrm{Na}$ Tabela 5 são apresentados os resultados dos ensaios para padronização da diluição das amostras-teste de doces de frutas em pasta e representam a média dos valores obtidos nas 4 amostras-teste de cada tipo de doce de fruta em pasta.

Tabela 5. Diluição e ${ }^{\circ}$ Brix das amostras-teste de doces de frutas em pasta. São Paulo, 1998/99.

\begin{tabular}{lccccc}
\hline $\begin{array}{l}\text { Tipos de doces de } \\
\text { frutas em pasta }\end{array}$ & $\begin{array}{c}\mathrm{N}^{\circ} \text { de } \\
\text { amostras }\end{array}$ & Diluição & ${ }^{\circ}$ Brix & Diluição & ${ }^{\circ}$ Brix \\
\hline Goiabada & 4 & $1+3$ & 5,0 & $1+4$ & 4,0 \\
Bananada & 4 & $1+3$ & 5,0 & $1+4$ & 3,8 \\
Marmelada & 4 & $1+3$ & 4,7 & $1+4$ & 3,7 \\
\hline
\end{tabular}

O método da AOAC International de centrifugação e diluição da amostra, estabelece uma mesma diluição para diferentes produtos elaborados com um mesmo tipo de fruta (por exemplo, geléia, polpa e néctar de pêssego), sendo os produtos de goiaba padronizados para diluição $1+3$, não havendo diluição descrita para banana $\mathrm{e}$ marmelo.

Após a diluição com solução de carboximetilcelulose na proporção $1+3$, as amostras-teste de goiabada apresentaram ${ }^{\circ}$ Brix 5,0 , ou seja, valor superior àquele obtido com as amostras-teste de geléia de goiaba ( ${ }^{\circ}$ Brix 4,0 , Tabela 3$)$. Utilizando-se a mesma diluição $(1+3)$, as amostras-teste de bananada e marmelada apresentaram ${ }^{\circ}$ Brix 5,0 e 4,7, respectivamente (Tabela 5).

Como nos ensaios realizados com as mesmas amostras dos três tipos de doces, empregando-se diluição $1+4$, resultaram valores de ${ }^{\circ}$ Brix entre 3,7 e 4,0 (Tabela 5) e, portanto, em intervalo semelhante àquele obtido para as amostras-teste de geléias de frutas (Tabela 3), adotou-se, por isso, essa última diluição. 


\subsubsection{Contagem de filamentos micelianos em doces de frutas em pasta}

$\mathrm{Na}$ Tabela 2-A (Anexos) são apresentados os resultados individuais obtidos nas análises das 57 amostras de doces de frutas em pasta e na Figura 5, os percentuais de amostras e os intervalos percentuais de campos positivos para filamentos micelianos.

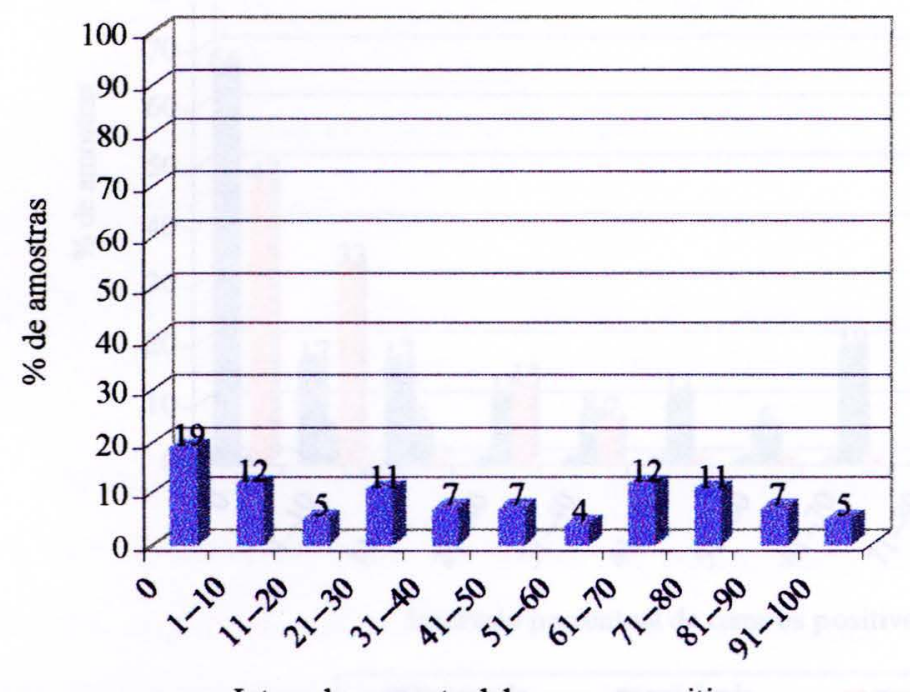

Intervalo percentual de campos positivos

Figura 5. Percentuais de amostras de doces de frutas em pasta quanto à contagem de filamentos micelianos, pelo método Howard. São Paulo, 1998/99.

Analogamente ao obtido nas análises de geléias de frutas, também para os doces em pasta foram encontrados valores elevados e com grande variabilidade na contagem de filamentos de fungos, chegando a $96 \%$ de campos positivos o valor máximo obtido, enquanto as amostras isentas representaram menos de $20 \%$ do total.

A distribuição dos percentuais de filamentos micelianos dos três tipos de doces de frutas em pasta estudados (Figura 6) e as estatísticas descritivas (Tabela 6), mostraram existir uma maior contaminação nas goiabadas, com $100 \%$ das amostras apresentando fungos, além de percentual máximo de campos positivos de $96 \%$ (intervalo de 91-100\%) (Figura 6). 
Seguiu-se a marmelada, com valor máximo de 35\% (Tabela 6), valor que pode ser considerado aberrante em relação aos demais resultados apresentados pelas amostras desse doce (Figura 7).

As amostras de bananada apresentaram o maior percentual (66\%) de amostras isentas de filamentos de fungos (Figura 6) e valor máximo de 12\% (Tabela 6).

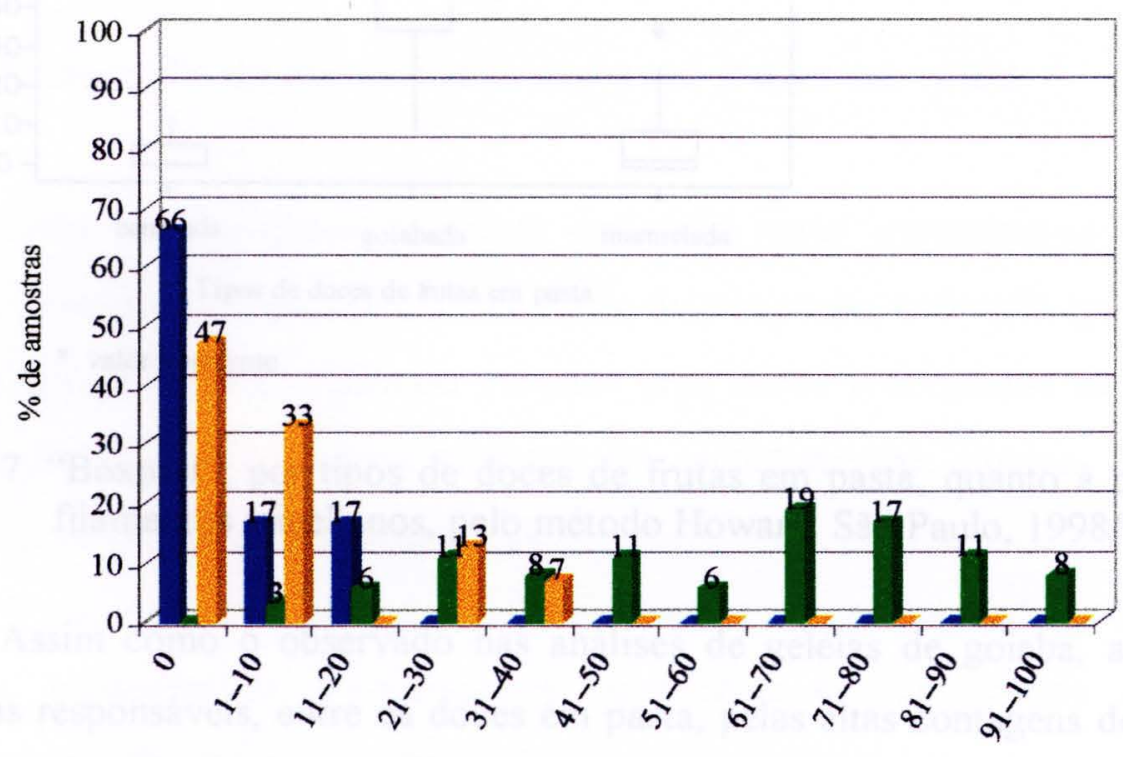

Intervalo percentual de campos positivos

bananada goiabada marmelada

Figura 6. Percentuais de amostras, por tipos de doces de frutas em pasta, quanto à contagem de filamentos micelianos, pelo método Howard. São Paulo, 1998/99.

Tabela 6. Estatísticas descritivas de percentuais de campos positivos com filamentos micelianos (método Howard), para as amostras de doces de frutas em pasta. São Paulo, 1998/99.

\begin{tabular}{lcrrrrrr}
\hline $\begin{array}{c}\text { Tipos de doces de } \\
\text { frutas em pasta }\end{array}$ & $\begin{array}{c}\mathrm{N}^{\circ} \text { de } \\
\text { amostras }\end{array}$ & Média & Mediana & Mínimo & Máximo & Q1 & Q3 \\
\hline Todos os tipos & 57 & 38,0 & 34,0 & 0,0 & 96,0 & 5,5 & 66,0 \\
\hline Bananada & 6 & 2,5 & 0,0 & 0,0 & 12,0 & 0,0 & 5,3 \\
Goiabada & 36 & 56,8 & 62,5 & 9,0 & 96,0 & 35,0 & 77,0 \\
Marmelada & 15 & 7,7 & 2,0 & 0,0 & 35,0 & 0,0 & 10,0 \\
\hline Q1: primeiro quartil & \multicolumn{7}{c}{ Q3: terceiro quartil }
\end{tabular}




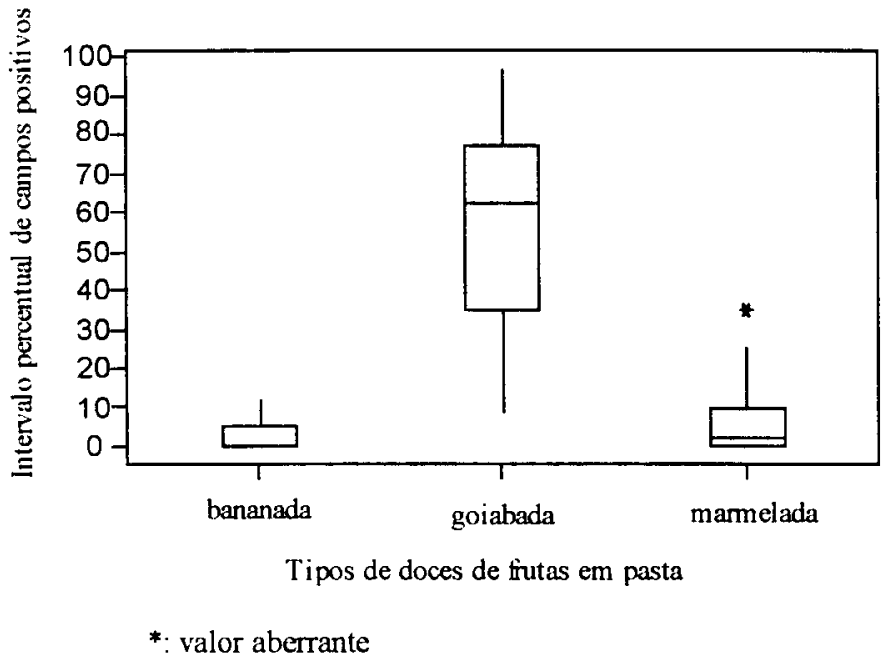

Figura 7. "Boxplot", por tipos de doces de frutas em pasta, quanto à contagem de filamentos micelianos, pelo método Howard. São Paulo, 1998/99.

Assim como o observado nas análises de geléias de goiaba, as goiabadas foram as responsáveis, entre os doces em pasta, pelas altas contagens de filamentos de fungos, sugerindo uma precária seleção das frutas "in natura" ou utilização de matéria-prima em condições higiênicas insatisfatórias.

Resultados semelhantes foram obtidos por ZAMBONI e col. (1981b) que, embora tenham utilizado diluição da amostra diferente da adotada neste estudo, encontraram amostras de goiabada contendo até 100\% de campos positivos para filamentos micelianos e de marmelada com até $30 \%$ de campos positivos.

Como, pela Resolução $n^{\circ}$ 9/78 da CTA/CNS e pelo Decreto Estadual $n^{\circ}$ 12.486/78, os doces de frutas em pasta não podem apresentar fungos em quantidade que indique a utilização de matéria-prima ou de processamento inadequadas, fica a critério de cada laboratório de microscopia de alimentos a definição do percentual de filamentos micelianos que vai tornar o produto em desacordo com a legislação, além da Portaria $n^{\circ} 451 / 97$ da SVS/MS estabelecer limite de $10^{3} / \mathrm{g}$ para bolores e leveduras.

Assim, neste estudo, não se pode considerar em desacordo com a legislação, $100 \%$ das amostras de goiabada, 53\% das marmeladas e 34\% das bananadas que 
apresentaram filamentos micelianos, o que mostra a importância de se adotar limites de tolerância para filamentos micelianos para esses produtos.

\subsection{FRUTAS EM CALDA}

\subsubsection{Adaptação do método Howard para frutas em calda}

Como nos produtos de frutas em calda estas encontram-se imersas em líquido, inteiras ou em pedaços, o método de determinação de fungos em produtos de abacaxi em pedaços e o método Howard para sucos processados de citros e de abacaxi, foram adaptados para as frutas em calda (abacaxi, ameixa, figo, goiaba, pêssego e salada de frutas) (item 4.3.2).

O uso dessa metodologia também permitiu realizar as análises de contagem Howard, contagem de filamentos de Geotrichum e determinação de matérias estranhas em uma mesma amostra.

O método mostrou-se adequado para a quantificação de filamentos de fungos nos produtos estudados, pois os poucos elementos histológicos vegetais presentes na calda, não interferiram no volume do sedimento do material centrifugado, resultando em sedimento $<5 \mathrm{~mL}$ e, portanto, possibilitando elevar o volume para $10 \mathrm{~mL}$ com água, conforme preconiza o método (Fluxograma 2 - Anexos), além de permitir montagem de lâminas adequadas para leitura.

A introdução da etapa de pesagem da amostra antes da retirada da alíquota para centrifugação foi necessária, pois nos rótulos das embalagens das frutas em calda constava o peso líquido drenado e era preciso saber o peso líquido (fruta + calda) para o método de contagem de filamentos micelianos de Geotrichum que, conforme exposto, foi realizada na mesma amostra.

Para as amostras de abacaxi em calda não foi necessário utilizar $\mathrm{HCl}$ para dissolver os cristais de oxalato de cálcio presentes nas células do mesocarpo da fruta, pois a calda do produto apresentou poucos elementos histológicos de abacaxi. 


\subsubsection{Contagem de filamentos micelianos em frutas em calda}

Os resultados individuais obtidos nas análises das 114 amostras de frutas em calda são apresentados na Tabela 3-A (Anexos).

A Figura 8 mostra os percentuais de amostras de frutas em calda quanto aos intervalos percentuais de campos positivos para filamentos micelianos; quase a metade das 114 amostras analisadas não continham filamentos de fungos e, no intervalo de 1 a $10 \%$ de campos positivos, encontraram-se $48 \%$ das amostras.

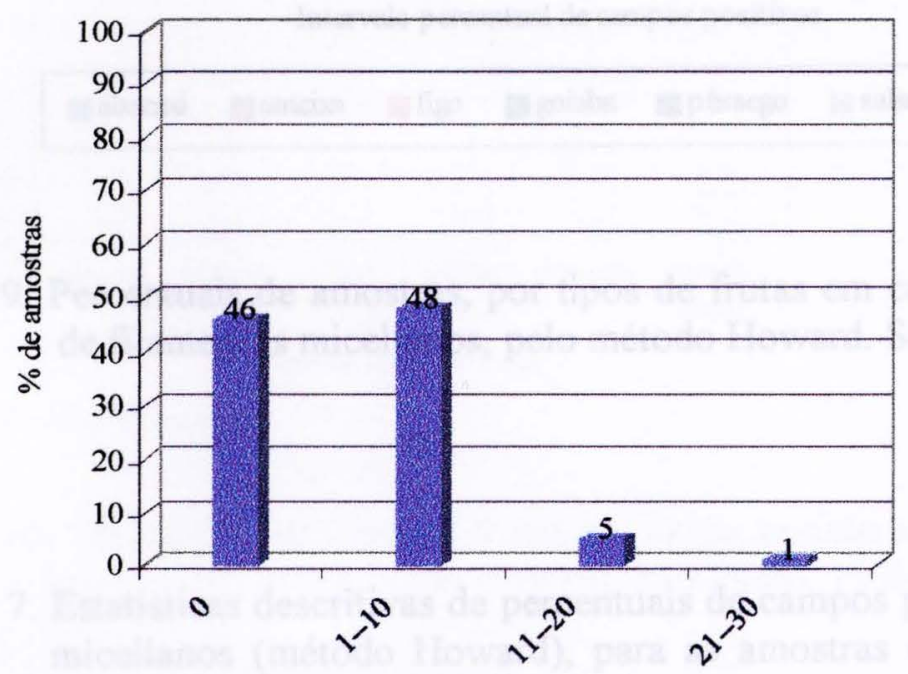

Intervalo percentual de campos positivos

Figura 8. Percentuais de amostras de frutas em calda quanto à contagem de filamentos micelianos, pelo método Howard. São Paulo, 1998/99.

Diferentemente do que ocorreu com as amostras de geléias de frutas e de doces de frutas em pasta, os 6 tipos de frutas em calda tiveram distribuição mais uniforme de contaminação por filamentos de fungos, conforme se observa na Figura 9.

Os baixos valores das médias e medianas mostram a pequena contaminação por filamentos de fungos nestes produtos, mesmo para as amostras de salada de frutas, que apresentam as frutas em pedaços menores (Tabela 7). 


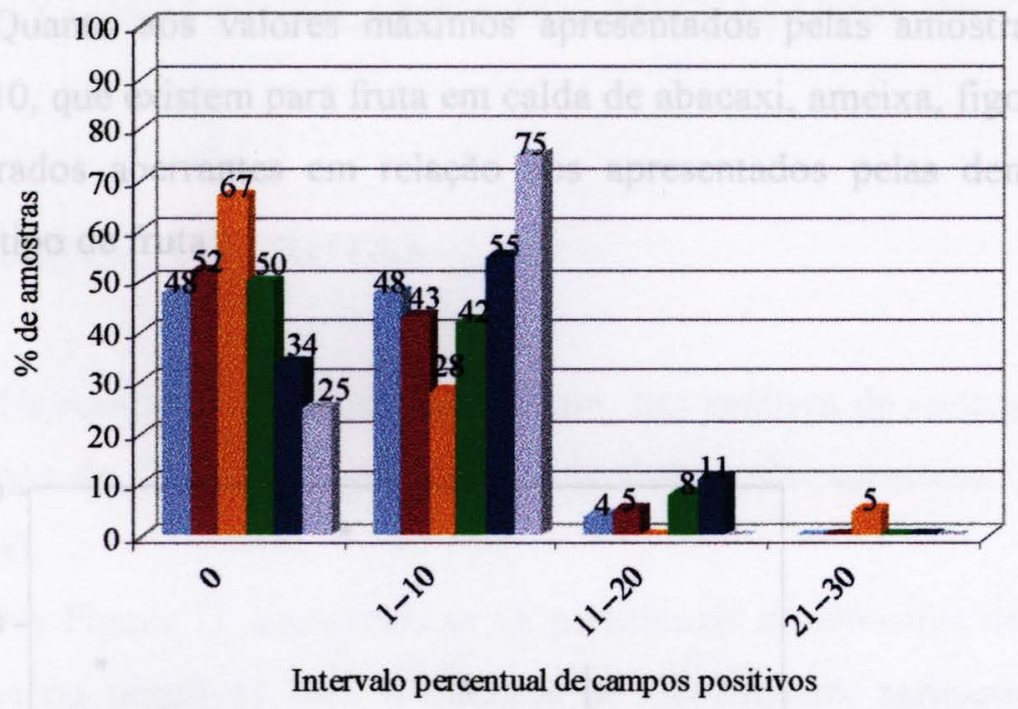

\begin{tabular}{|c|c|c|c|c|}
\hline abacaxi & ameixa & figo & goiaba & pêssego \\
\hline
\end{tabular}

Figura 9. Percentuais de amostras, por tipos de frutas em calda, quanto à contagem de filamentos micelianos, pelo método Howard. São Paulo, 1998/99.

Tabela 7. Estatísticas descritivas de percentuais de campos positivos com filamentos micelianos (método Howard), para as amostras de frutas em calda. São Paulo, 1998/99.

\begin{tabular}{lccccccc}
\hline $\begin{array}{c}\text { Tipos de frutas } \\
\text { em calda }\end{array}$ & $\begin{array}{c}\mathrm{N}^{\circ} \text { de } \\
\text { amostras }\end{array}$ & Média & Mediana & Mínimo & Máximo & Q1 & Q3 \\
\hline Todos os tipos & 114 & 2,8 & 1,0 & 0,0 & 27,0 & 0,0 & 4,0 \\
\hline Abacaxi & 21 & 2,4 & 1,0 & 0,0 & 17,0 & 0,0 & 3,5 \\
Ameixa & 21 & 2,0 & 0,0 & 0,0 & 11,0 & 0,0 & 3,5 \\
Figo & 21 & 2,4 & 0,0 & 0,0 & 27,0 & 0,0 & 3,0 \\
Goiaba & 12 & 2,3 & 0,5 & 0,0 & 15,0 & 0,0 & 2,8 \\
Pêssego & 27 & 4,4 & 3,0 & 0,0 & 17,0 & 0,0 & 7,0 \\
Salada de frutas & 12 & 2,2 & 2,0 & 0,0 & 5,0 & 0,3 & 3,8 \\
\hline \multicolumn{7}{c}{ Q1: primeiro quartil } &
\end{tabular}


Quanto aos valores máximos apresentados pelas amostras, observa-se na Figura 10, que existem para fruta em calda de abacaxi, ameixa, figo e goiaba, valores considerados aberrantes em relação aos apresentados pelas demais amostras do mesmo tipo de fruta.

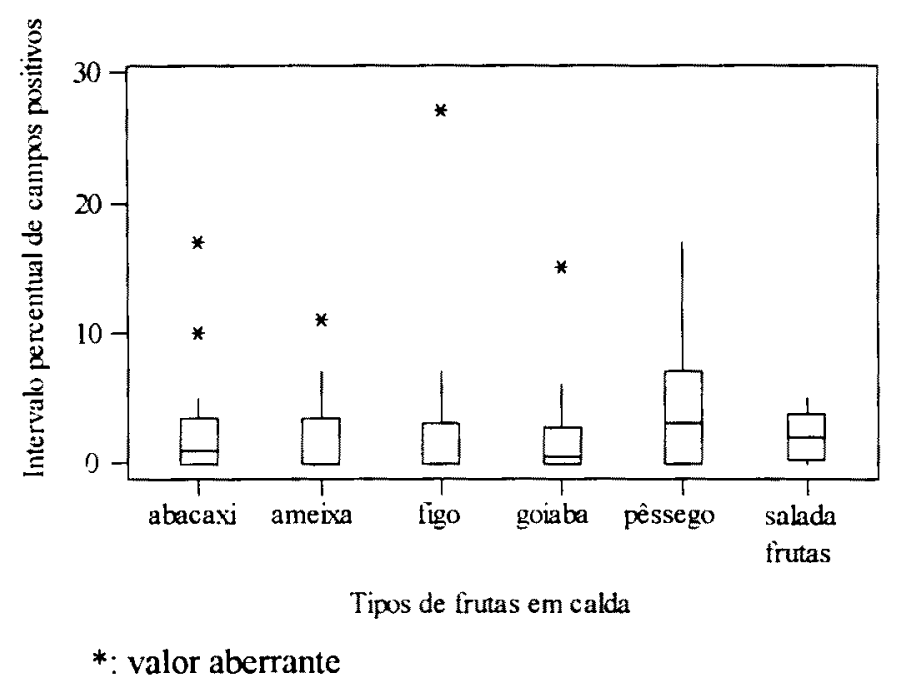

Figura 10. "Boxplot" por tipos de frutas em calda, quanto à contagem de filamentos micelianos, pelo método Howard. São Paulo, 1998/99.

Como a legislação de alimentos não especifica limites de tolerância de filamentos micelianos para as frutas em calda, pelos resultados obtidos, $54 \%$ das amostras analisadas estariam em desacordo com a legislação (dentre eles, $75 \%$ das amostras de saladas de frutas).

$\mathrm{O}$ que torna esse tipo de doce menos contaminado por fungos do que as geléias e os doces em pasta (que apresentam a fruta triturada) é o fato do produto ser composto por frutos inteiros, em metades ou fatiados (exceto a salada de frutas que as apresenta em pequenos pedaços), que devem estar em excelente estado de conservação para torná-lo atraente ao consumidor. 


\section{B. CONTAGEM DE FILAMENTOS MICELIANOS DE Geotrichum}

\subsection{GELÉIAS DE FRUTAS}

Os resultados obtidos, por amostra, nas análises de contagem de filamentos micelianos de Geotrichum em geléias de frutas, são apresentados na Tabela 4-A (Anexos).

Na Figura 11 encontram-se os percentuais de amostras de geléias de frutas positivas ou negativas para filamentos de Geotrichum, agrupados por intervalos. Verifica-se que a maioria das amostras de geléias de frutas (77\%) não continha filamentos micelianos do fungo, enquanto $23 \%$ apresentaram de 1 até 8000 filamentos em $100 \mathrm{~mL}$ de preparação.

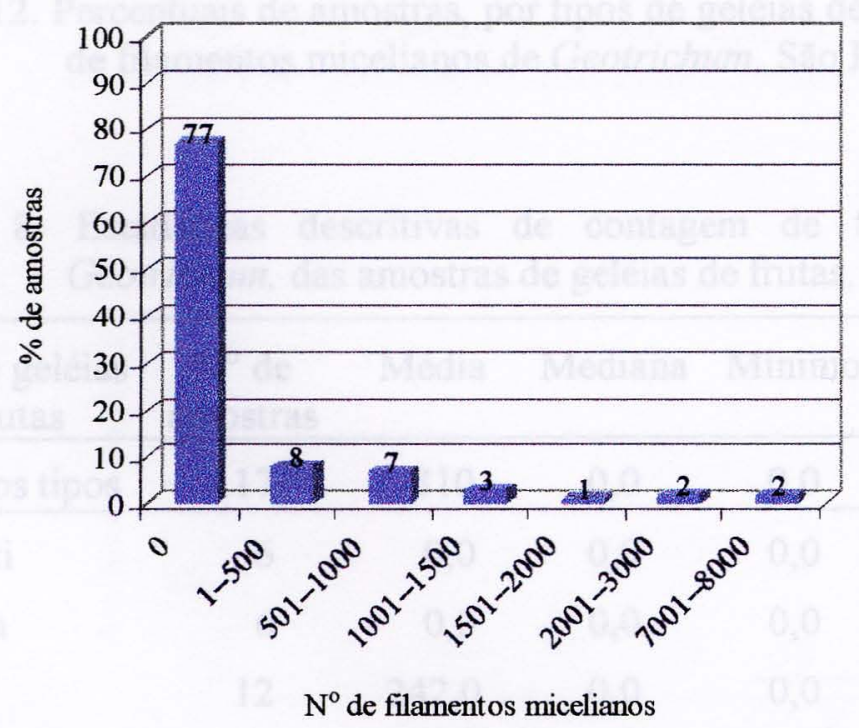

Figura 11. Percentuais de amostras de geléias de frutas, quanto à contagem de filamentos micelianos de Geotrichum. São Paulo, 1998/99.

Considerando-se os tipos de geléias, verifica-se que aquelas de abacaxi, ameixa e figo estavam isentas desse fungo (Figura 12). As geléias de goiaba e morango apresentaram as maiores contagens de filamentos em termos de valores máximos (Tabela 8), para os demais tipos esses valores oscilaram entre 200 e 2.000 . 


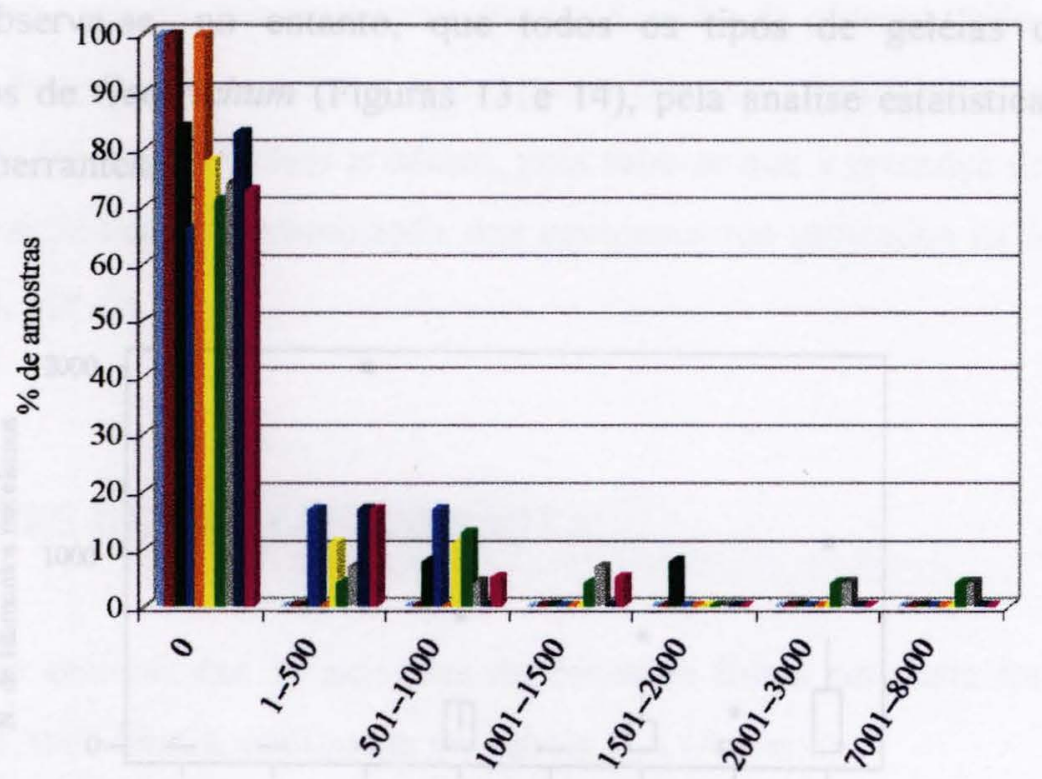

$\mathrm{N}^{\circ}$ de filamentos micelianos

\begin{tabular}{|lllll|}
\hline $\begin{array}{l}\text { abacaxi } \\
\text { framboesa }\end{array}$ & ameixa & amora & damasco & figo \\
goiaba & morango & aêssego & uva
\end{tabular}

Figura 12. Percentuais de amostras, por tipos de geléias de frutas, quanto à contagem de filamentos micelianos de Geotrichum. São Paulo, 1998/99.

Tabela 8. Estatísticas descritivas de contagem de filamentos micelianos de Geotrichum, das amostras de geléias de frutas. São Paulo, 1998/99.

\begin{tabular}{|c|c|c|c|c|c|c|c|}
\hline $\begin{array}{c}\text { Tipos de geléias } \\
\text { de frutas }\end{array}$ & $\begin{array}{c}\mathrm{N}^{\circ} \text { de } \\
\text { amostras }\end{array}$ & Média & Mediana & Mínimo & Máximo & Q1 & Q3 \\
\hline Todos os tipos & 117 & 310 & 0,0 & 0,0 & $8.000,0$ & 0,0 & 0,0 \\
\hline Abacaxi & 6 & 0,0 & 0,0 & 0,0 & 0,0 & 0,0 & 0,0 \\
\hline Ameixa & 6 & 0,0 & 0,0 & 0,0 & 0,0 & 0,0 & 0,0 \\
\hline Amora & 12 & 242,0 & 0,0 & 0,0 & $2.000,0$ & 0,0 & 0,0 \\
\hline Damasco & 6 & 133,0 & 0,0 & 0,0 & 700,0 & 0,0 & 250,0 \\
\hline Figo & 3 & 0,0 & 0,0 & 0,0 & 0,0 & 0,0 & 0,0 \\
\hline Framboesa & 9 & 100,0 & 0,0 & 0,0 & 600,0 & 0,0 & 150,0 \\
\hline Goiaba & 24 & 588,0 & 0,0 & 0,0 & $7.400,0$ & 0,0 & 575,0 \\
\hline Morango & 27 & 541,0 & 0,0 & 0,0 & $8.000,0$ & 0,0 & 100,0 \\
\hline Pêssego & 6 & 33,3 & 0,0 & 0,0 & 200,0 & 0,0 & 50,0 \\
\hline Uva & 18 & 155,6 & 0,0 & 0,0 & $1.100,0$ & 0,0 & 325,0 \\
\hline
\end{tabular}


Observa-se, no entanto, que todos os tipos de geléias que continham filamentos de Geotrichum (Figuras 13 e 14), pela análise estatística, apresentaram valores aberrantes.

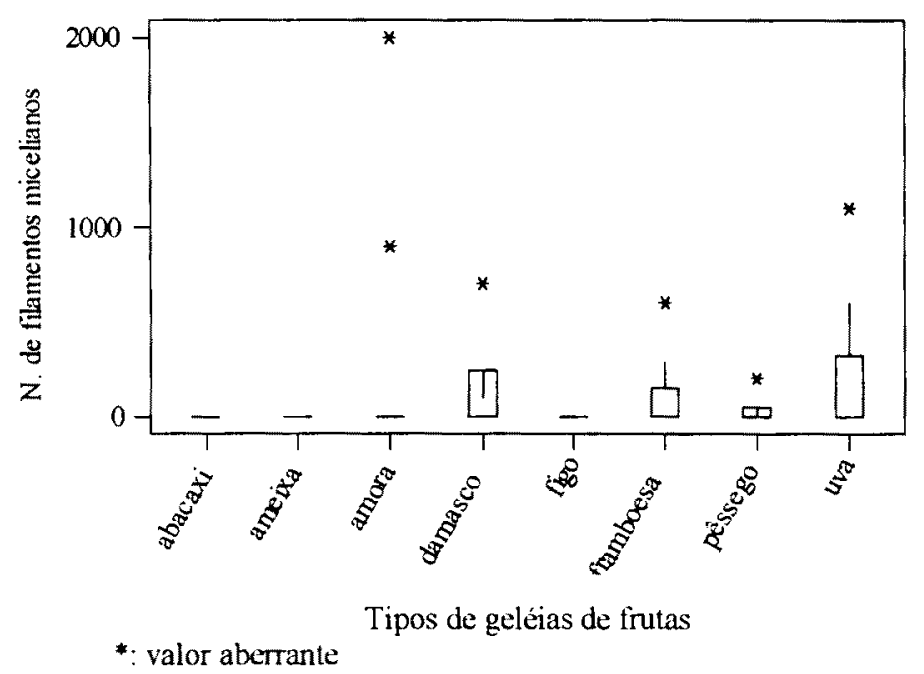

Figura 13. "Boxplot" para geléias de frutas, quanto à contagem de filamentos micelianos de Geotrichum. São Paulo, 1998/99.

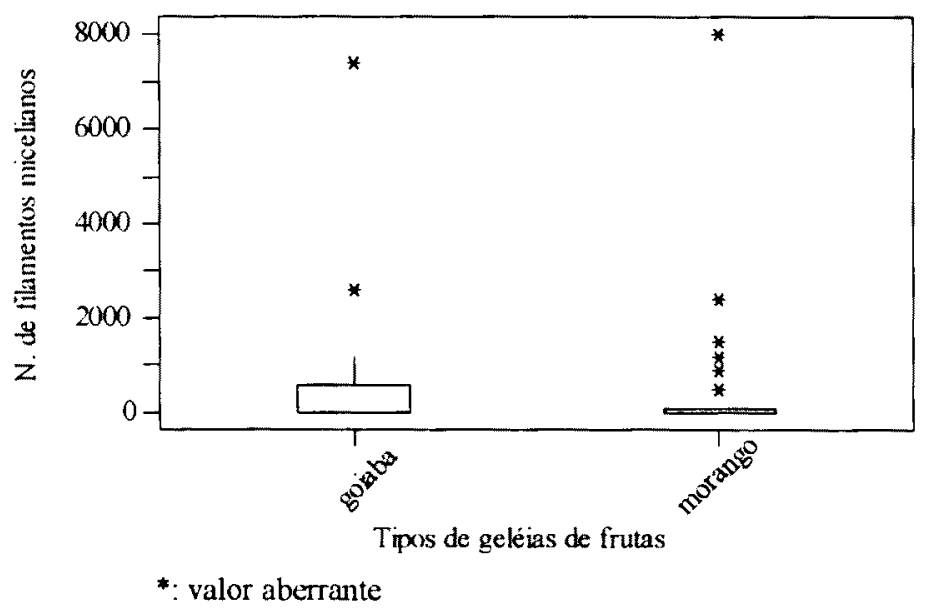

Figura 14. "Boxplot" para geléias de frutas, quanto à contagem de filamentos micelianos de Geotrichum. São Paulo, 1998/99.

ZAMBONI (1986) analisou geléias de goiaba e de pêssego, encontrando amostras com até 15.000 filamentos de Geotrichum e, portanto, superiores aos 
obtidos neste estudo, principalmente quanto à geléia de pêssego. Não se pode inferir o motivo deste fato, mas, talvez, com o passar dos anos, foram incrementadas as boas práticas de fabricação desses produtos, pois sabe-se que a presença de filamentos de Geotrichum indica a contaminação dos equipamentos utilizados na industrialização das frutas, por ele.

\subsection{DOCES DE FRUTAS EM PASTA}

Nas análises das 57 amostras de doces de frutas em pasta foram obtidos os resultados, individuais, constantes na Tabela 5-A (Anexos).

Assim como ocorreu com as geléias, um alto percentual de amostras de doces de frutas em pasta não apresentou filamentos de Geotrichum (Figura 15), especialmente as bananadas, que estavam isentas desse contaminante (Figura 16).

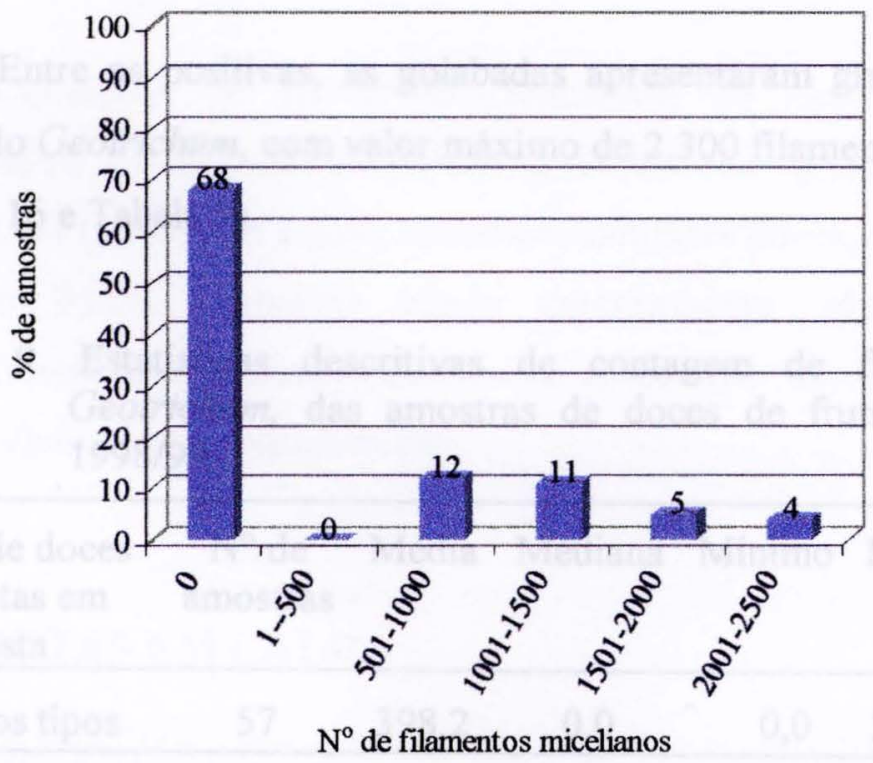

Figura 15. Percentuais de amostras de doces de frutas em pasta, quanto à contagem de filamentos micelianos de Geotrichum. São Paulo, 1998/99. 


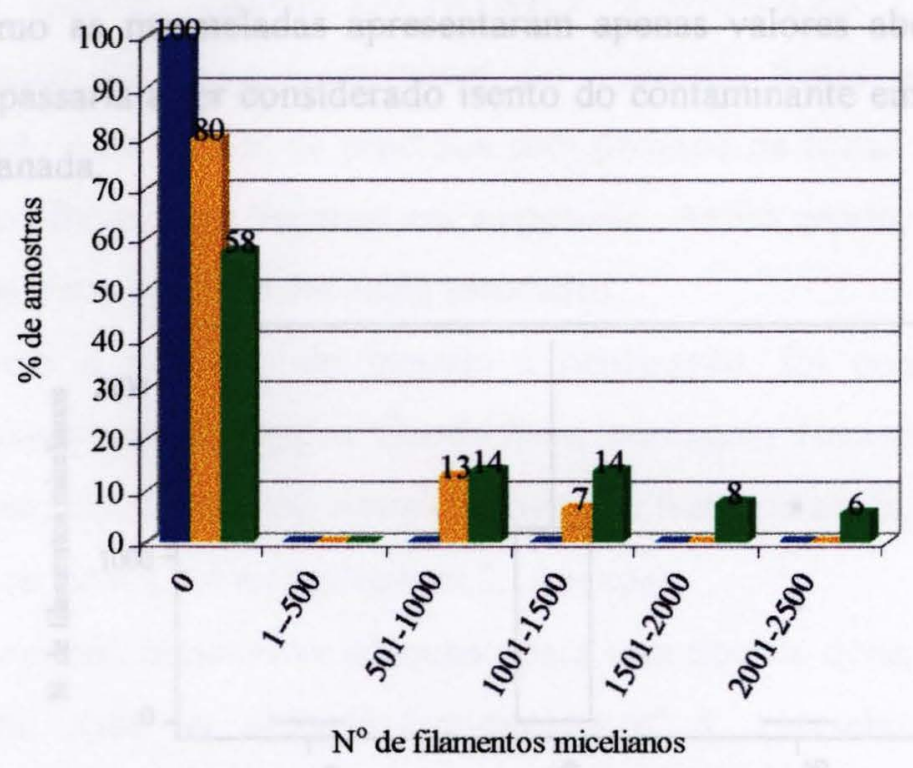

bananada 筙 marmelada goiabada

Figura 16. Percentuais de amostras, por tipos de doces de frutas em pasta, quanto à contagem de filamentos micelianos de Geotrichum. São Paulo, 1998/99.

Entre as positivas, as goiabadas apresentaram grande número de amostras contendo Geotrichum, com valor máximo de 2.300 filamentos $/ 100 \mathrm{~mL}$ de preparação (Figura 16 e Tabela 9).

Tabela 9. Estatísticas descritivas de contagem de filamentos micelianos de Geotrichum, das amostras de doces de frutas em pasta. São Paulo, 1998/99.

\begin{tabular}{|c|c|c|c|c|c|c|c|}
\hline $\begin{array}{c}\text { Tipos de doces } \\
\text { de frutas em } \\
\text { pasta }\end{array}$ & $\begin{array}{c}\mathrm{N}^{\circ} \text { de } \\
\text { amostras }\end{array}$ & Média & Mediana & Mínimo & Máximo & Q1 & Q3 \\
\hline Todos os tipos & 57 & 398,2 & 0,0 & 0,0 & $2.300,0$ & 0,0 & 800,0 \\
\hline Bananada & 6 & 0,0 & 0,0 & 0,0 & 0,0 & 0,0 & 0,0 \\
\hline Goiabada & 36 & 553,0 & 0,0 & 0,0 & $2.300,0$ & 0,0 & $1.175,0$ \\
\hline Marmelada & 15 & 187,0 & 0,0 & 0,0 & $1.300,0$ & 0,0 & 0,0 \\
\hline
\end{tabular}


Como as marmeladas apresentaram apenas valores aberrantes (Figura 17), esse doce passaria a ser considerado isento do contaminante em questão, juntamente com a bananada.

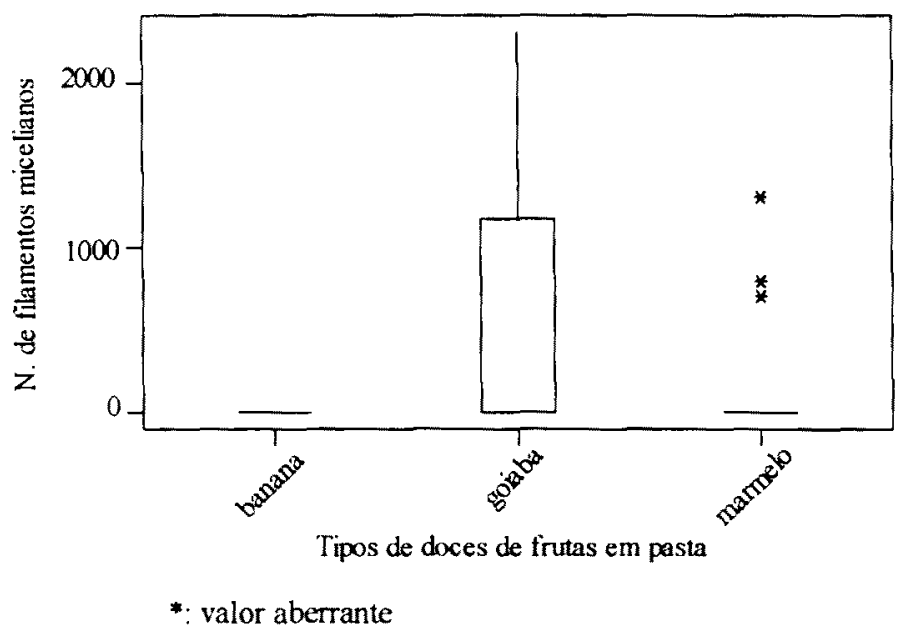

Figura 17. "Boxplot" por tipos de doces de frutas em pasta, quanto à contagem de filamentos micelianos de Geotrichum. São Paulo, 1998/99.

Contagens de até 30.000 filamentos de Geotrichum em amostras de marmeladas, $60.000 \mathrm{em}$ bananadas e $80.000 \mathrm{em}$ goiabadas foram obtidas por ZAMBONI (1986), em estudo realizado com esses doces, de marcas comercializadas em São Paulo. Conforme citado anteriormente, uma rigorosa inspeção de equipamentos e utensílios utilizados na elaboração desses doces evitaria ou, pelo menos, diminuiria a contaminação.

\subsection{FRUTAS EM CALDA}

\subsubsection{Adaptação do método de contagem de filamentos micelianos de Geotrichum para frutas em calda}

Nos procedimentos analíticos descritos na $\mathrm{AOAC}$ não há metodologia especifica para avaliação de filamentos micelianos de Geotrichum em frutas em calda. 
No entanto, segundo CICHOWICZ e BANDLER (1982), o método de "determinação de fungo Geotrichum em vegetais, frutas e sucos enlatados" é recomendado para análise de produtos com pedaços de frutas imersos em líquido e com poucos fragmentos vegetais em suspensão. Assim sendo, adaptou-se o método para os seis tipos de frutas em calda estudados.

Como o princípio do método é peneiração, foi possível realizar as três análises (contagem de fungos Geotrichum, contagem Howard e determinação de matérias estranhas), em uma mesma amostra de fruta em calda, após as modificações propostas no item 4.3.4 e Fluxograma 2 (Anexos).

O método mostrou-se adequado para este tipo de doce, uma vez que a calda do produto, após ser drenada em peneira $\mathrm{n}^{\circ} 8$, apresentou poucos elementos histológicos da fruta, além de passar pela peneira $n^{\circ} 230$ sem saturar a malha. $O$ residuo retido na peneira e transferido para o tubo de centrífuga apresentou volume inferior a $10 \mathrm{~mL}$ em $90 \%$ das análises, o que permitiu a diluição da amostra sem necessidade da etapa de centrifugação; nas demais amostras, o volume ficou entre 10 e $30 \mathrm{~mL}$.

\subsubsection{Contagem de filamentos micelianos de Geotrichum em frutas em calda}

Os resultados obtidos, por amostra, nas análises de contagem de filamentos micelianos de Geotrichum em frutas em calda, são apresentados na Tabela 6-A (Anexos).

Na Figura 18 observa-se que apenas 53\% das amostras de frutas em calda analisadas não apresentaram filamentos de Geotrichum; entre as amostras positivas a maior parte (38\%) continha até 50 filamentos de fungos/100g de amostra. Encontrouse maior contaminação nas amostras de pêssego em calda (Figura 19), não só em relação ao número de filamentos (valor máximo de 392 filamentos, Tabela 10) como, também, ao percentual de amostras contendo esse contaminante $(74 \%)$. Após o pêssego, seguiu-se o abacaxi em calda (Figura 19) em termos de contaminação. 


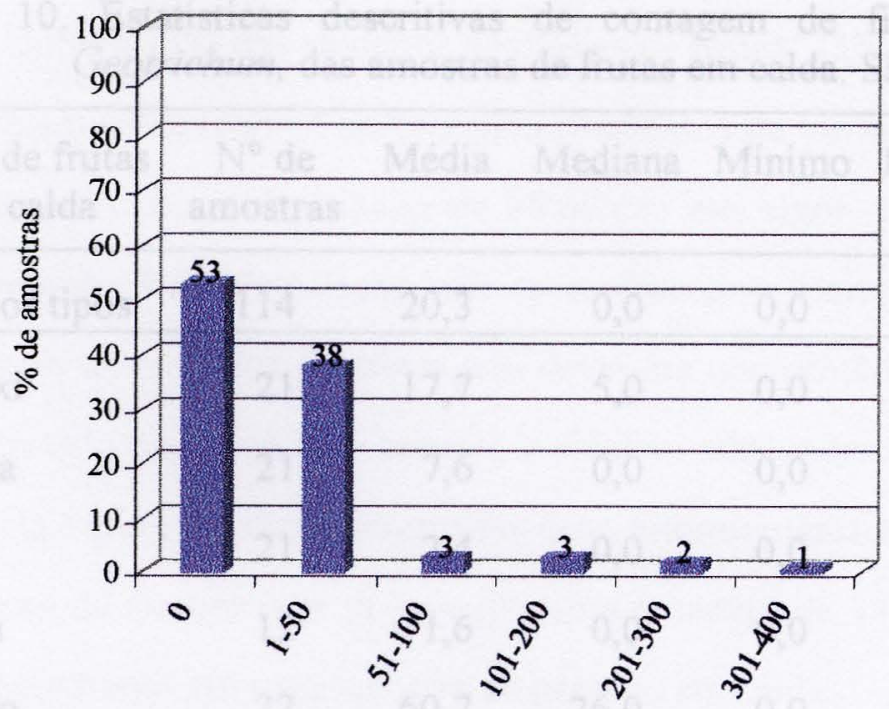

$\mathrm{N}^{\circ}$ de filamentos micelianos

Figura 18. Percentuais de amostras de frutas em calda, quanto à contagem de filamentos micelianos de Geotrichum. São Paulo, 1998/99.

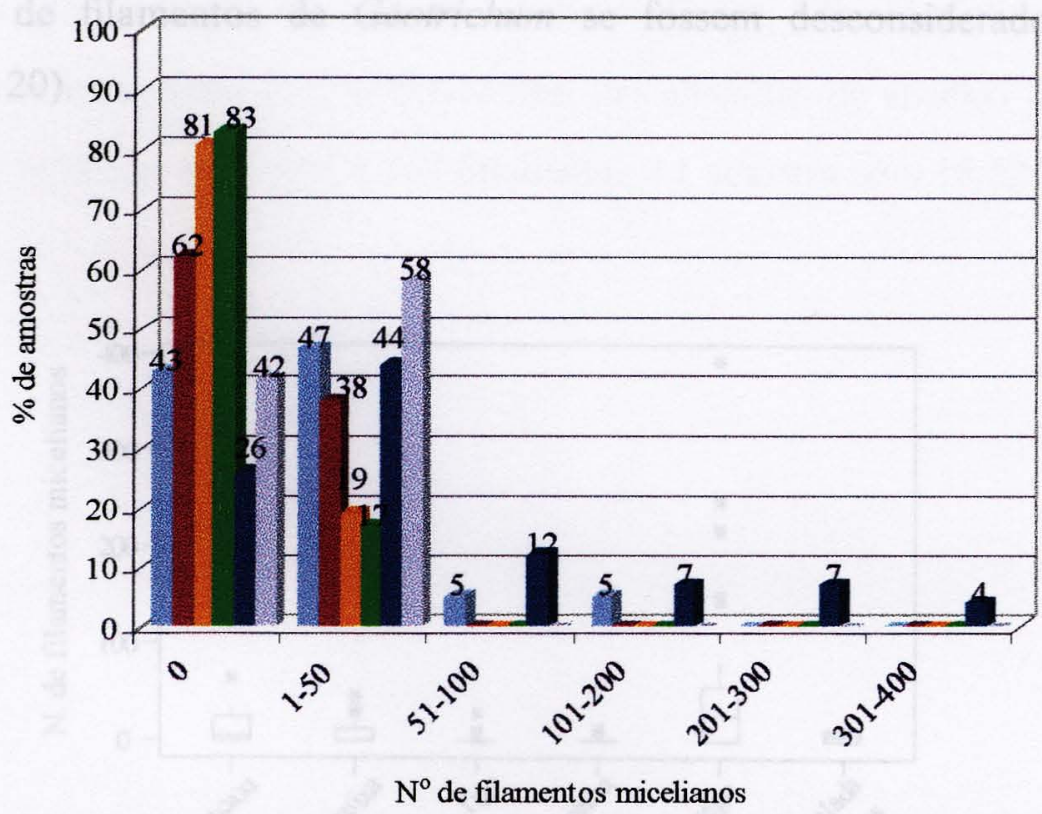

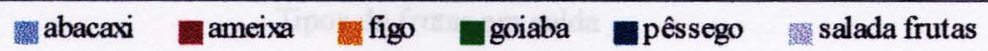

Figura 19. Percentuais de amostras, por tipos de frutas em calda, quanto à contagem de filamentos micelianos de Geotrichum. São Paulo, 1998/99. 
Tabela 10. Estatísticas descritivas de contagem de filamentos micelianos de Geotrichum, das amostras de frutas em calda. São Paulo, 1998/99.

\begin{tabular}{lrrrrrrr}
\hline $\begin{array}{c}\text { Tipos de frutas } \\
\text { em calda }\end{array}$ & $\begin{array}{c}N^{\circ} \text { de } \\
\text { amostras }\end{array}$ & Média & Mediana & Mínimo & Máximo & Q1 & Q3 \\
\hline Todos os tipos & 114 & 20,3 & 0,0 & 0,0 & 392,0 & 0,0 & 17,5 \\
\hline Abacaxi & 21 & 17,7 & 5,0 & 0,0 & 138,0 & 0,0 & 23,5 \\
Ameixa & 21 & 7,6 & 0,0 & 0,0 & 47,0 & 0,0 & 11,5 \\
Figo & 21 & 2,4 & 0,0 & 0,0 & 28,0 & 0,0 & 0,0 \\
Goiaba & 12 & 1,6 & 0,0 & 0,0 & 13,0 & 0,0 & 0,0 \\
Pêssego & 27 & 60,7 & 26,0 & 0,0 & 392,0 & 0,0 & 56,0 \\
Salada de frutas & 12 & 6,4 & 5,5 & 0,0 & 19,0 & 0,0 & 12,8 \\
\hline Q1: primeiro quartil & \multicolumn{7}{c}{ Q3: terceiro quartil }
\end{tabular}

Dos 6 tipos de frutas em calda estudados, somente as saladas de frutas não apresentaram valores aberrantes, enquanto o figo e a goiaba seriam considerados isentos de filamentos de Geotrichum se fossem desconsiderados esses valores (Figura 20).

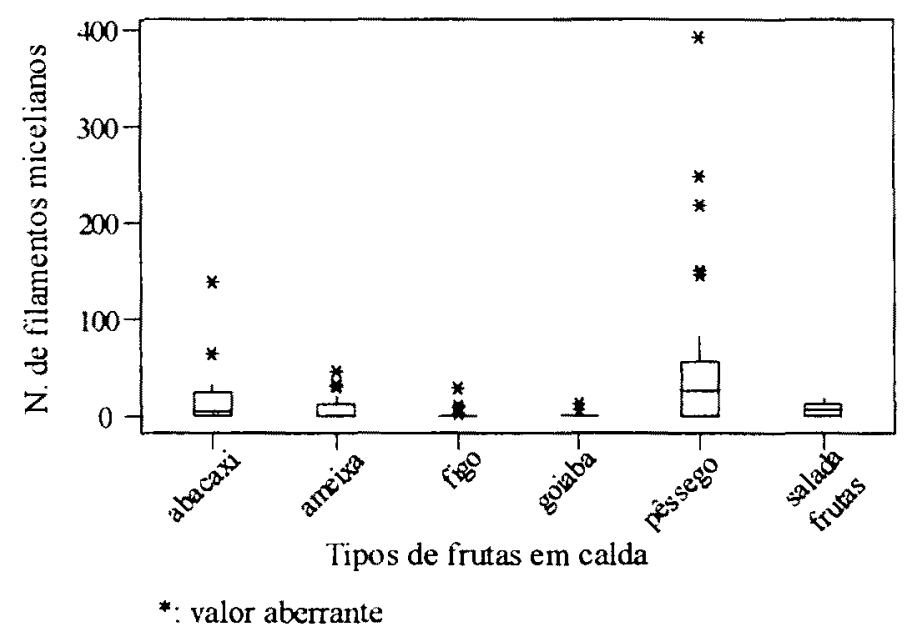

Figura 20. Percentuais de amostras, por tipos de frutas em calda, quanto à contagem de filamentos micelianos de Geotrichum. São Paulo, 1998/99. 
Embora $23 \%$ das amostras de geléias de frutas, $32 \%$ de doces em pasta e $47 \%$ de frutas em calda tenham apresentado filamentos de Geotrichum, estando, portanto, em desacordo com a legislação de alimentos em vigor, deve-se pensar que numa futura revisão dessa legislação não se estabeleçam limites de tolerância para esse fungo, pois os produtos de frutas não deveriam apresentá-lo, uma vez que ele pode ser controlado e evitado com práticas higiênicas adequadas de máquinas e utensílios.

$\mathrm{Na}$ Figura 21 são apresentadas duas fotomicrografias dos mesmos filamentos micelianos de Geotrichum (a primeira com aumento de 140 vezes e a segunda com 800), encontrados em uma amostra de pêssego em calda.

EISENBERG e CICHOWICZ (1977) relatam os resultados de contagem de filamentos micelianos de Geotrichum, encontrados em análises de 500 amostras de pêssego (em pedaços) e de abacaxi (em pedaços e também triturados) enlatados, colhidas no comércio dos Estados Unidos e analisadas nos laboratórios do FDA, empregando o método proposto por CICHOWICZ e EISENBERG (1974). Nas amostras de pêsssego, 3\% estavam isentas do fungo, 58\% continham entre 1 e 200 e 1 amostra apresentou 11.730 filamentos; nas amostras de abacaxi encontraram 34\% isentas, $56 \%$ contendo de 1 a 500 filamentos e 1 amostra com 18.525 . 


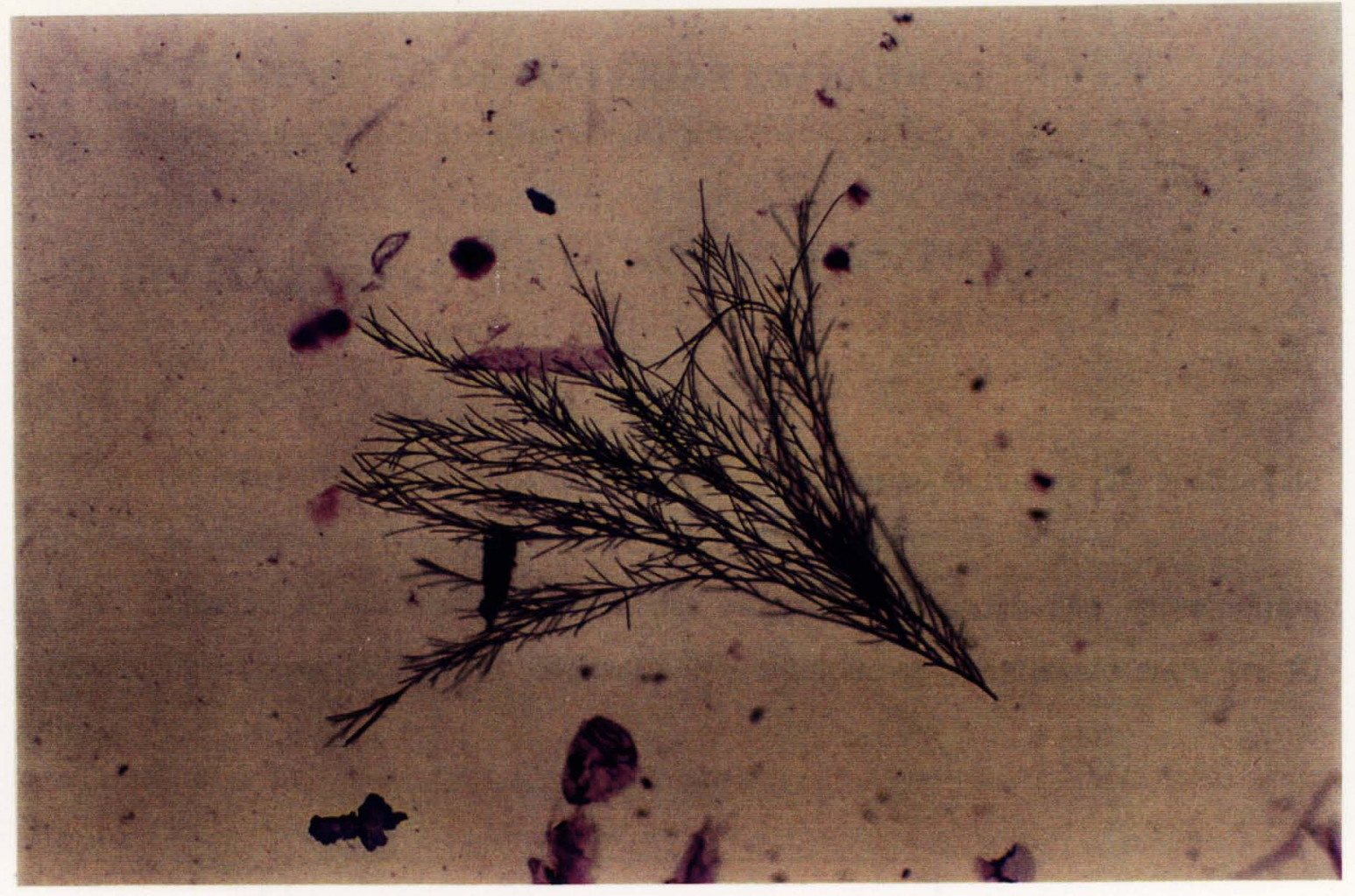

A

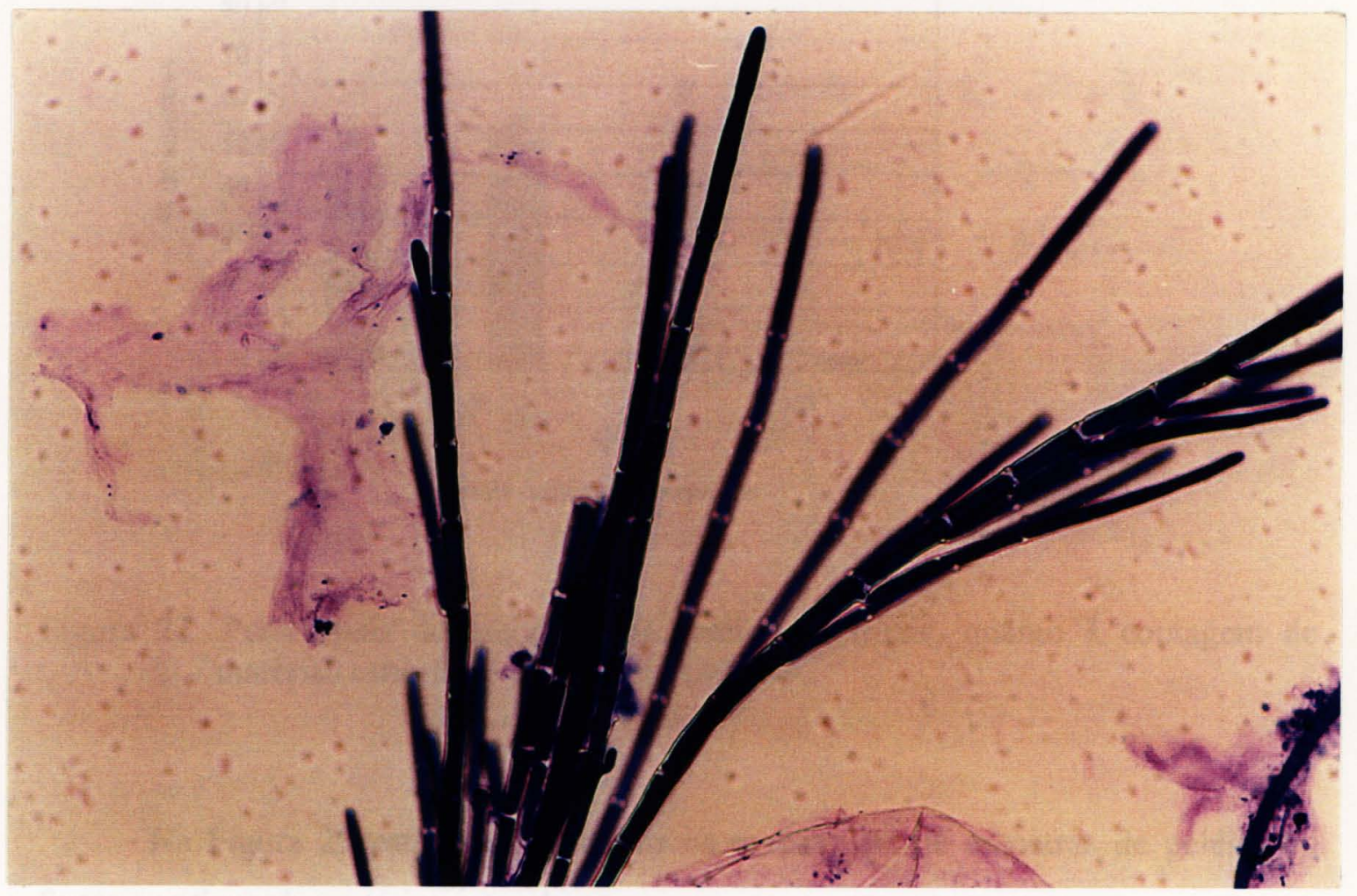

B

Figura 21. Fungo Geotrichum, corado com cristal violeta, encontrado em pêssego em calda. Filamentos micelianos: A (140x), B (800x). 


\section{DETERMINAÇÃO DE MATÉRIAS ESTRANHAS}

\subsection{GELÉIAS DE FRUTAS}

Os resultados individuais da contagem de matérias estranhas das análises de geléias de frutas são apresentados na Tabela 7-A (Anexos).

Observa-se que somente $44 \%$ das amostras analisadas não apresentaram matérias estranhas (Figura 22), enquanto $49 \%$ situaram-se no intervalo entre 1 e 10 delas.

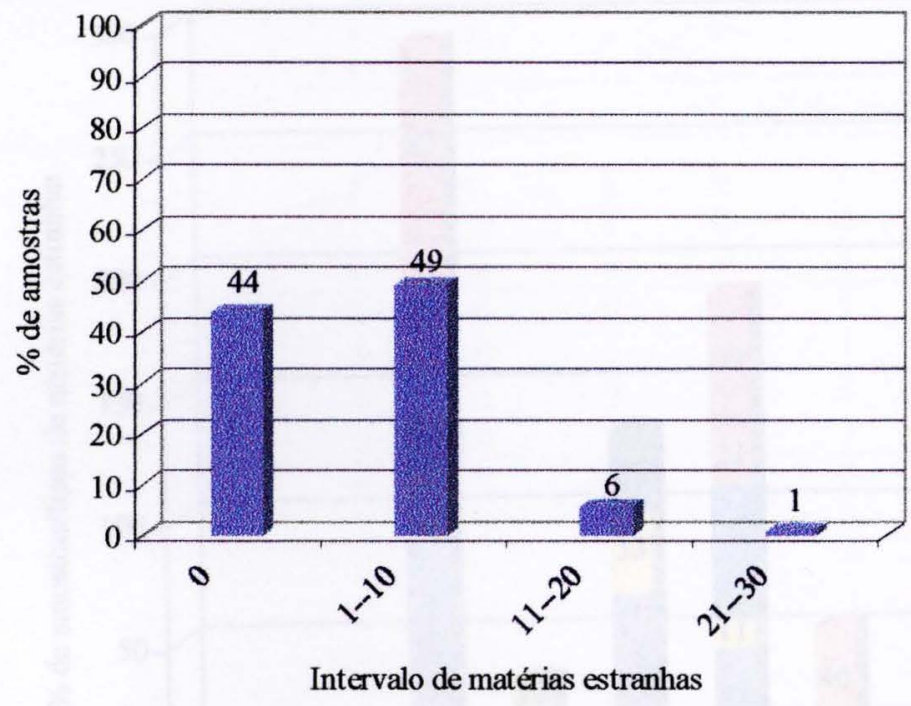

Figura 22. Percentuais de amostras de geléias de frutas, quanto à contagem de matérias estranhas. São Paulo, 1998/99.

Na Figura 23 estão representados os percentuais de amostras de geléias de frutas por tipos de matérias estranhas.

Fragmentos de insetos foram encontrados com maior freqüência, pois, apenas as geléias de abacaxi, ameixa e figo estavam isentas do mesmo. 
Ácaros foram isolados em 4 tipos de geléias, sendo o percentual elevado naquelas de amora ( $83 \%$ ) e de framboesa (56\%).

Observa-se, ainda, que nenhuma geléia apresentou simultaneamente os 7 tipos de matérias estranhas identificadas. No entanto, em quatro tipos delas (amora, framboesa, morango e uva) foram encontrados 6 dos 7 tipos de contaminantes, apesar do fato não acontecer em cada amostra desses doces; foi, inclusive, nas geléias de amora e de framboesa que ocorreram os percentuais mais significativos de matérias estranhas.

Pêlo de roedor foi encontrado apenas em uma amostra, que era de geléia de damasco.

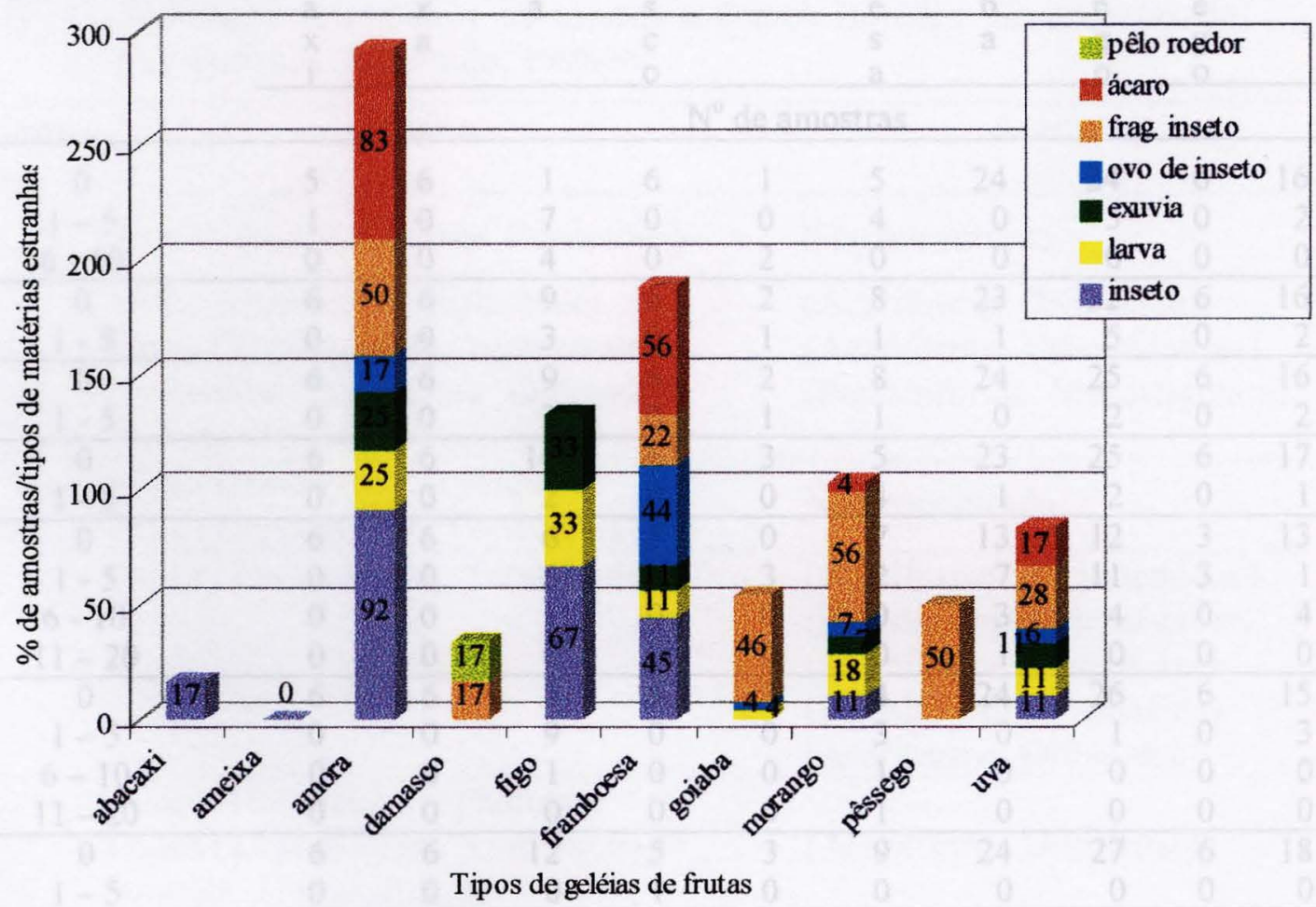

Figura 23. Percentuais de amostras de geléias de frutas, por tipos de matérias estranhas. São Paulo, 1998/99. 
$\mathrm{Na}$ Tabela 11 são apresentados os tipos e quantidades (por intervalos) de matérias estranhas. Ácaros e fragmentos de insetos foram as matérias estranhas encontradas em maior número por amostra: 15 ácaros em 1 amostra de geléia de framboesa (intervalo de 11-20) e 17 fragmentos de insetos em 1 amostra de geléia de goiaba (intervalo de 11-20).

Tabela 11. Número de amostras por tipos de matérias estranhas isoladas de geléias de frutas. São Paulo, 1998/99.

Matérias estranhas

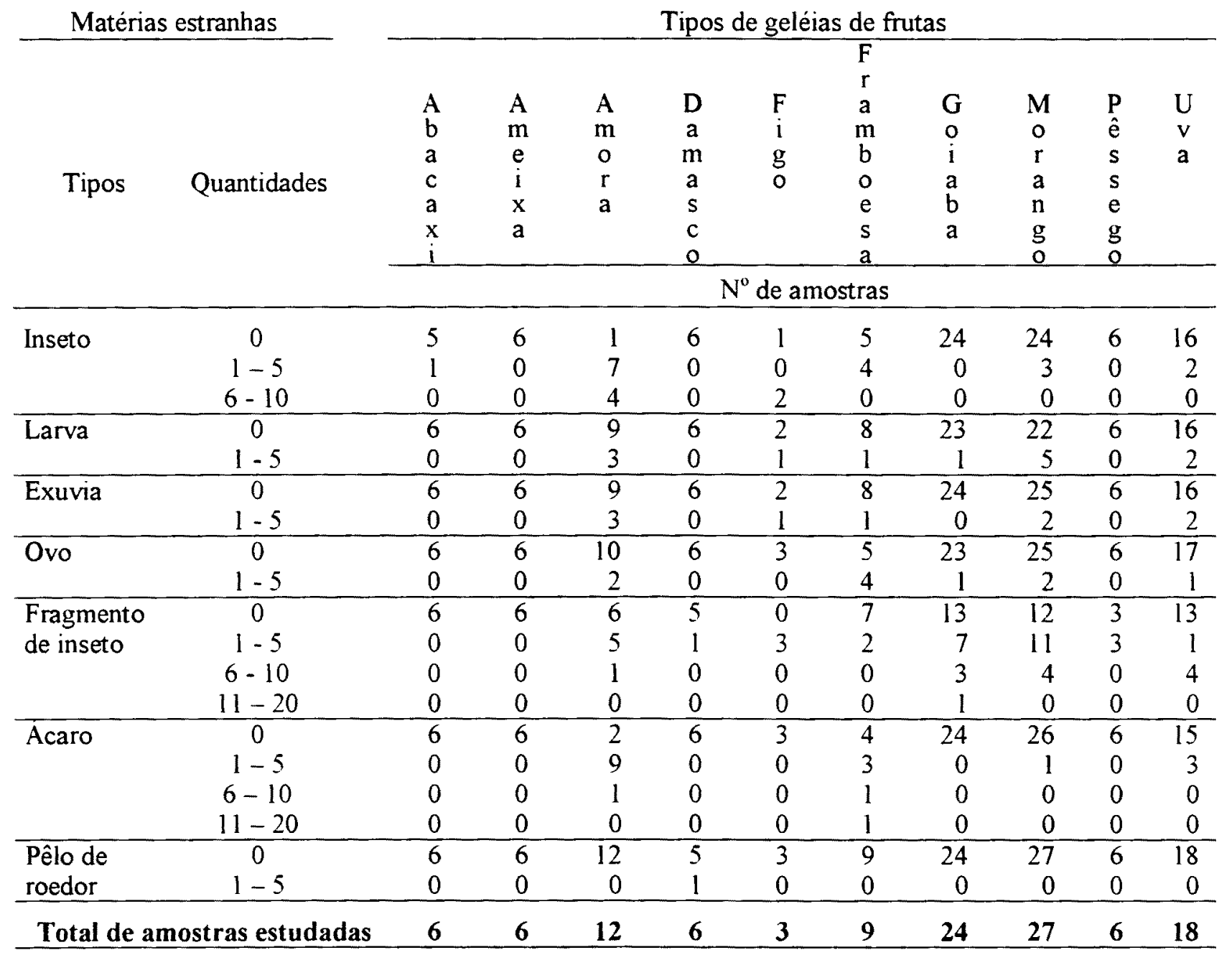

Os altos niveis de matérias estranhas observados nas geléias, principalmente de amora, framboesa e figo, sugerem a utilização de frutas contaminadas que foram 
mantidas na linha de produção, por um processo de seleção ou de lavagem inadequado.

Como a legislação de alimentos em vigor exige ausência de sujidades, parasitos e larvas, $56 \%$ das geléias analisadas seriam consideradas em desacordo com a mesma, valor que poderia ser diminuido se fossem estabelecidos limites de tolerância para fragmentos de insetos, como ocorre em outros produtos como, por exemplo, os derivados de trigo.

Não foi possível proceder à classificação taxonômica de todos os insetos e ácaros isolados de amostras de geléias de frutas pelo fato deles se apresentarem muito deformados, provavelmente devido ao processamento da fruta para elaboração do produto. Aqueles passiveis de classificação foram relacionados na Tabela 12.

Tabela 12. Classificação taxonômica de insetos e ácaros isolados de amostras de geléias de frutas. São Paulo, 1998/99.

\begin{tabular}{|c|c|c|}
\hline $\begin{array}{c}\text { Tipos de geléias } \\
\text { de frutas }\end{array}$ & Insetos & Ácaros \\
\hline Abacaxi & Cochonilha (Homoptera: Coccoidea) & Não encontrado \\
\hline Amora & $\begin{array}{l}\text { Afidio (Homoptera: Aphididae) } \\
\text { Tripes (Thysanoptera: Terebrantia) } \\
\text { Cochonilha (Homoptera: Coccoidea) } \\
\text { Formiga (Hymenoptera) }\end{array}$ & $\begin{array}{l}\text { (Acariforme: Oribatidae) } \\
\text { (Acariforme: Tenuipalpidae) } \\
\text { (Parasitiforme: Mesostigmata) }\end{array}$ \\
\hline Figo & $\begin{array}{l}\text { Afidio (Homoptera: Aphididae) } \\
\text { Trips (Thysanoptera: Terebrantia) }\end{array}$ & Não encontrado \\
\hline Framboesa & Tripes (Thysanoptera: Terebrantia) & $\begin{array}{l}\text { (Acariforme: Tarsonemidae) } \\
\text { (Parasitiforme: Phytoseidae) } \\
\text { (Acariforme: Eriophydae) } \\
\text { (Parasitiforme: Gamasida) } \\
\text { (Acariforme: Oribatidae) }\end{array}$ \\
\hline Morango & $\begin{array}{l}\text { Afidio (Homoptera: Aphididae) } \\
\text { Tripes (Thysanoptera: Terebrantia) } \\
\text { Formiga (Hymenoptera) }\end{array}$ & (Acariforme: Oribatidae) \\
\hline Uva & $\begin{array}{l}\text { Cochonilha (Homoptera: Coccoidea) } \\
\text { Psocoptera (Psocidae) }\end{array}$ & $\begin{array}{l}\text { (Acariforme: Oribatidae } \\
\text { (Acariforme: Tarsonemidae) } \\
\text { (Acariforme: Tenuipalpidae) }\end{array}$ \\
\hline
\end{tabular}

Nas Figuras 24 a 26 são apresentadas fotomicrografias de matérias estranhas isoladas de amostras de geléias de frutas. 


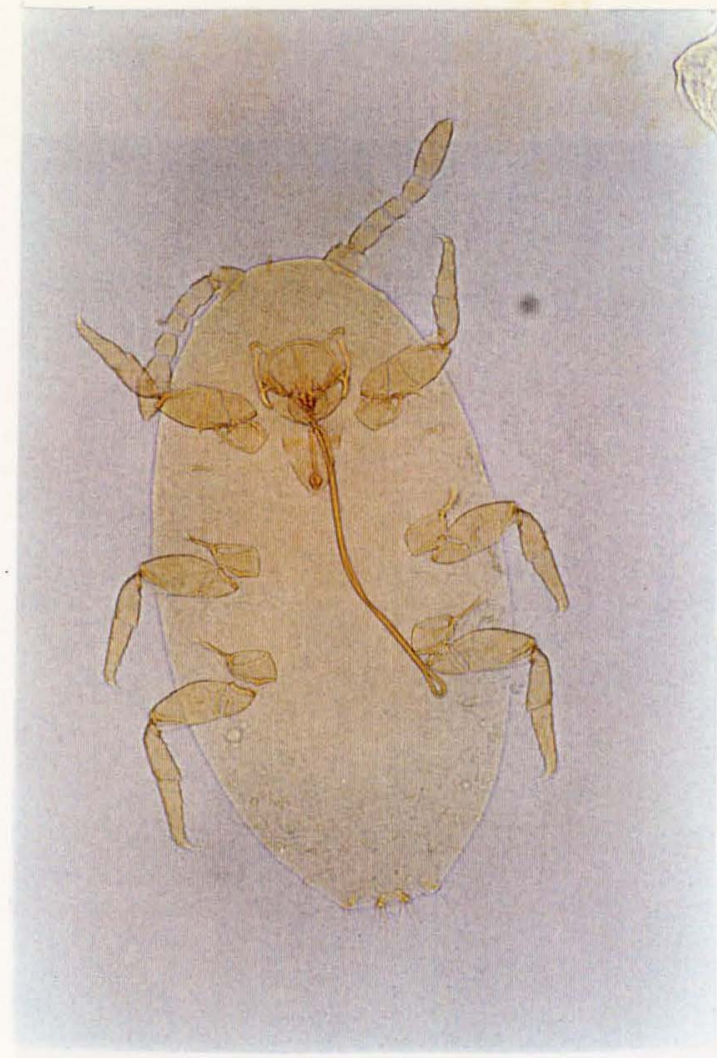

A

$\mathrm{C}$

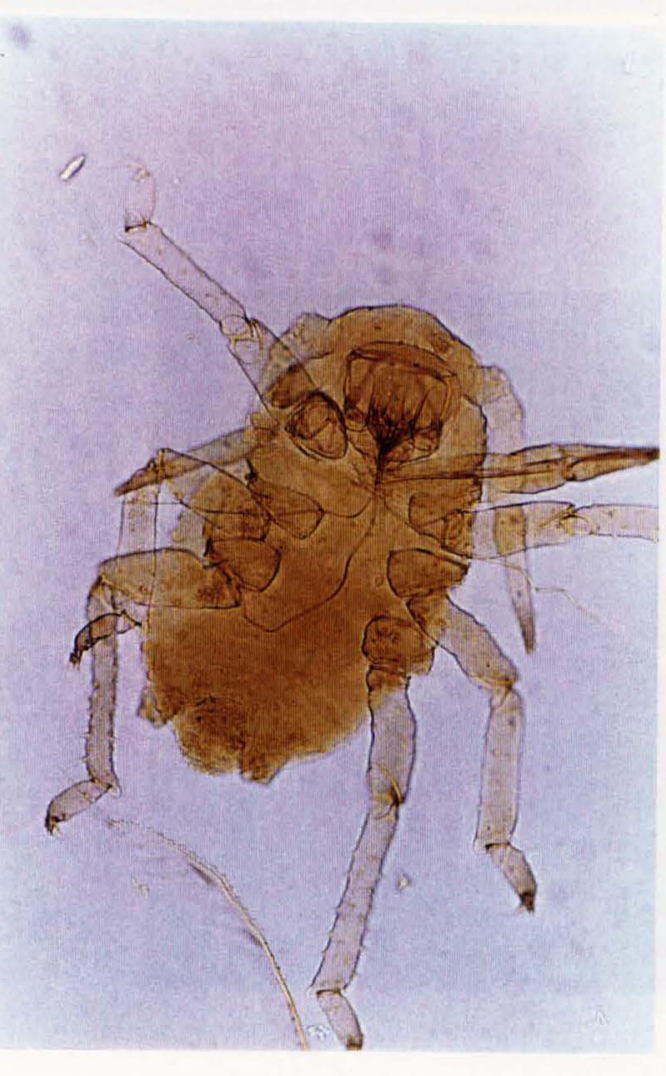

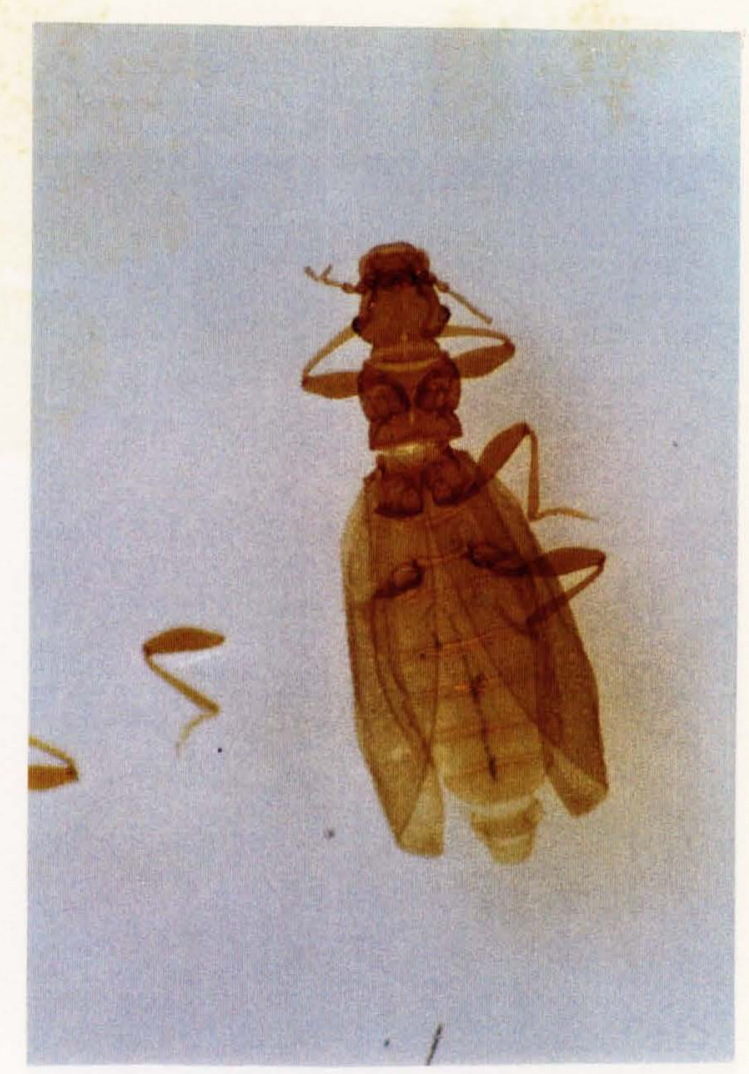

B

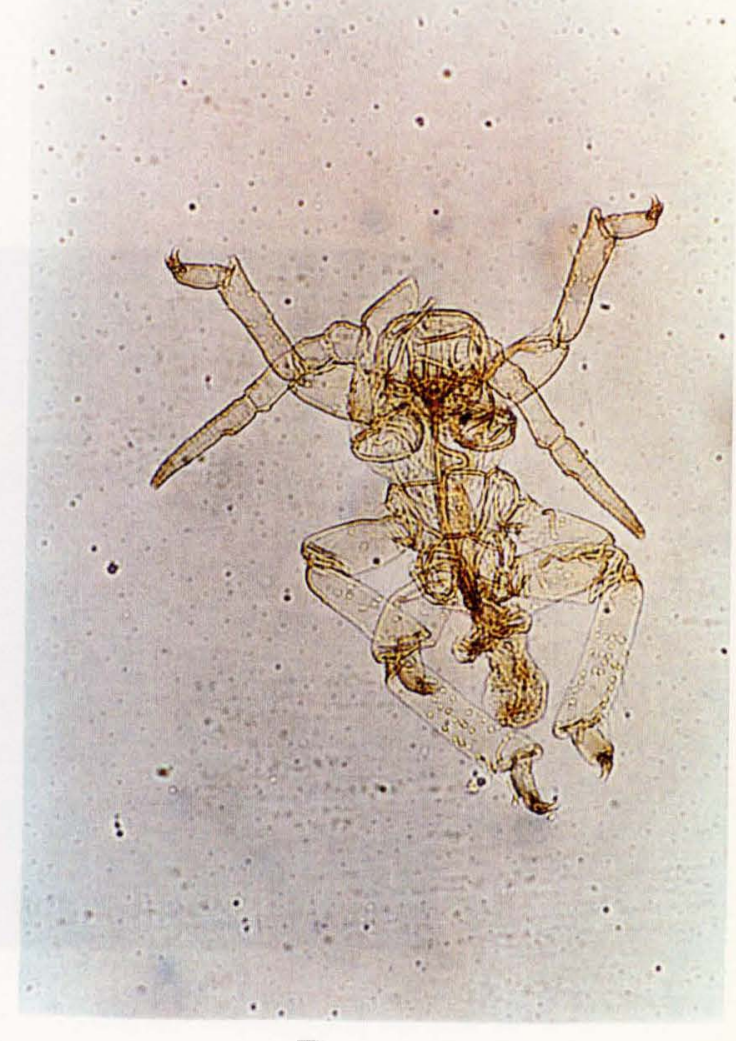

D

Figura 24. Matérias estranhas enontradas em geléias de frutas. A: Coccoidea (400x), B: Psocidae (104x), C: Aphididae (400x), D: exúvia de inseto (400x). 


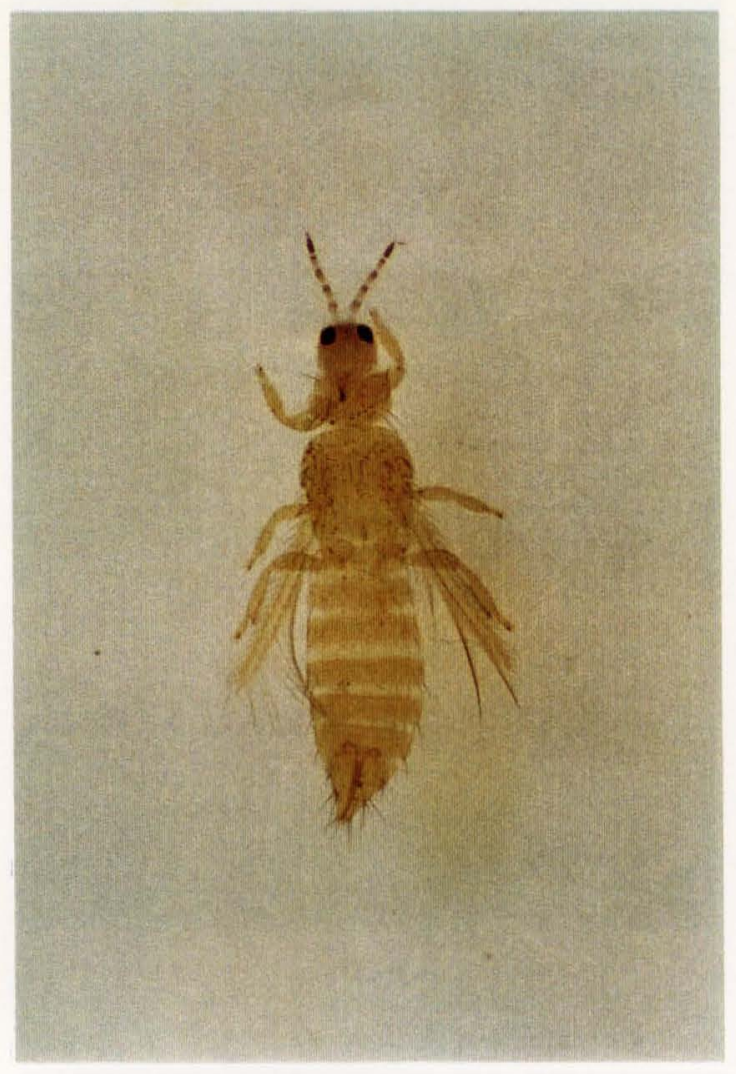

A

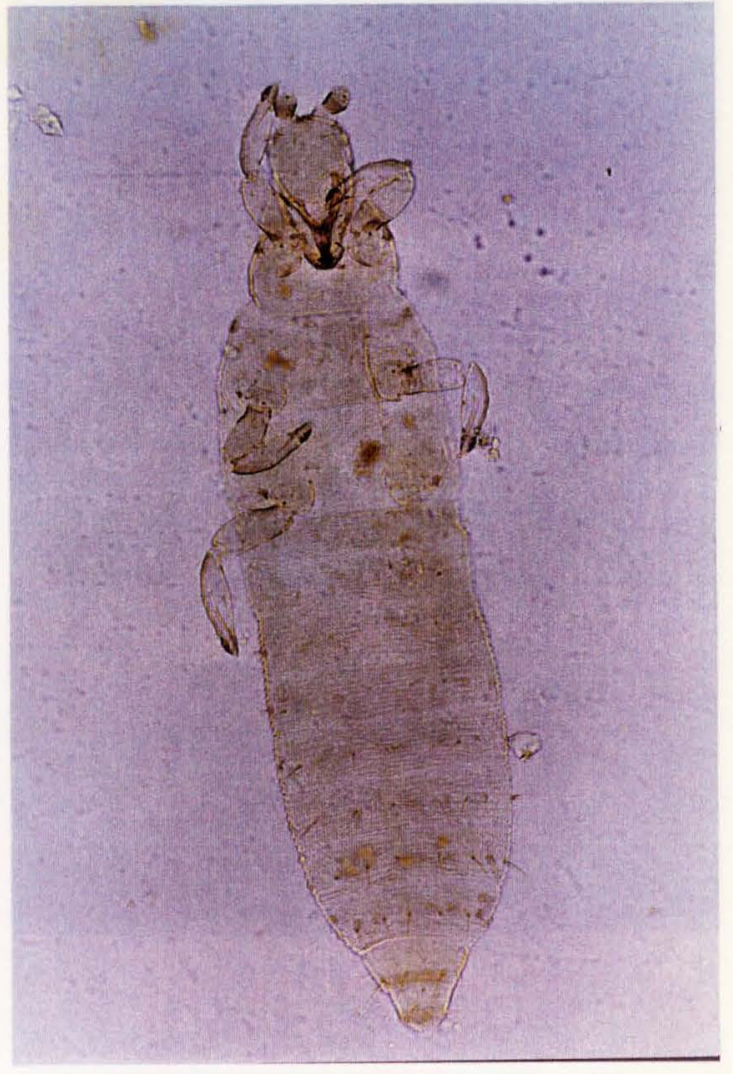

B

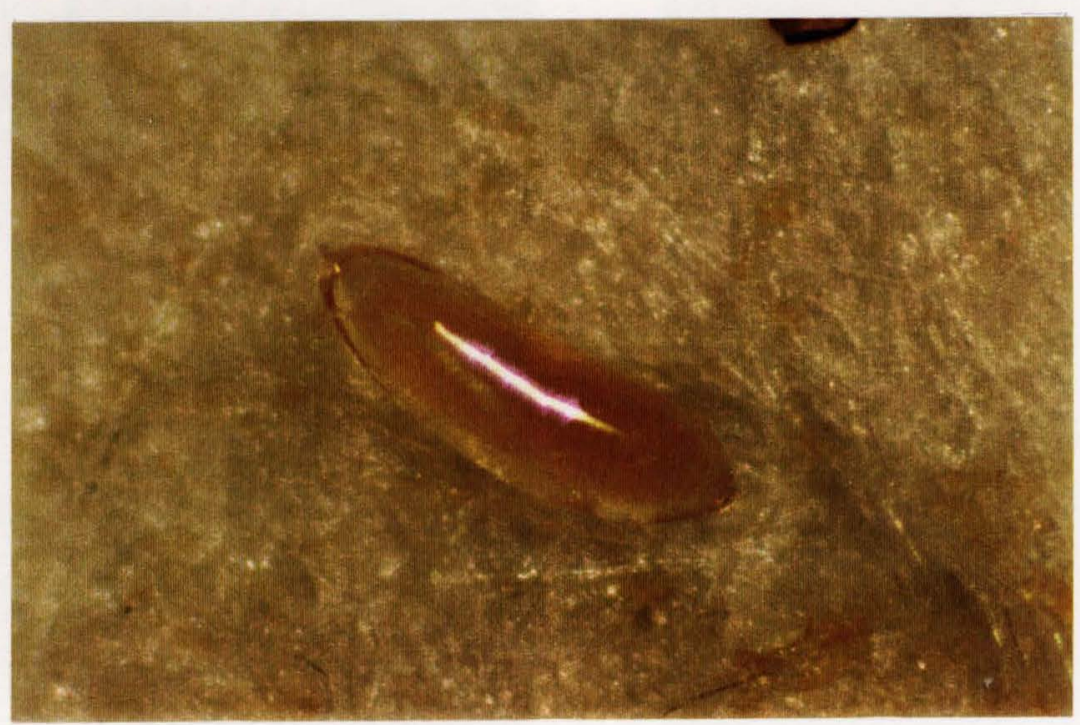

C

Figura 25. Matérias estranhas encontradas em geléias de frutas. A: Subordem Terebrantia adulto $(200 x)$, B: Subordem Terebrantia - forma imatura $(400 x)$, C: ovo de inseto $(160 \mathrm{x})$. 


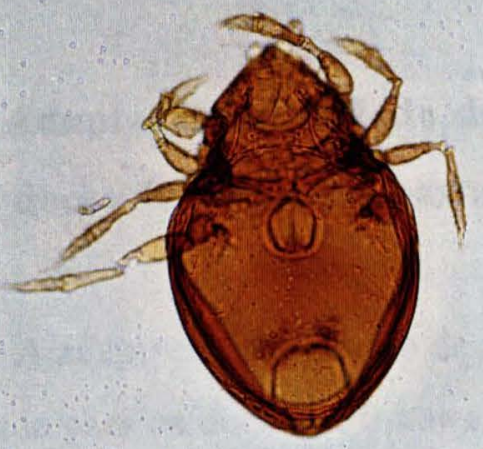

A

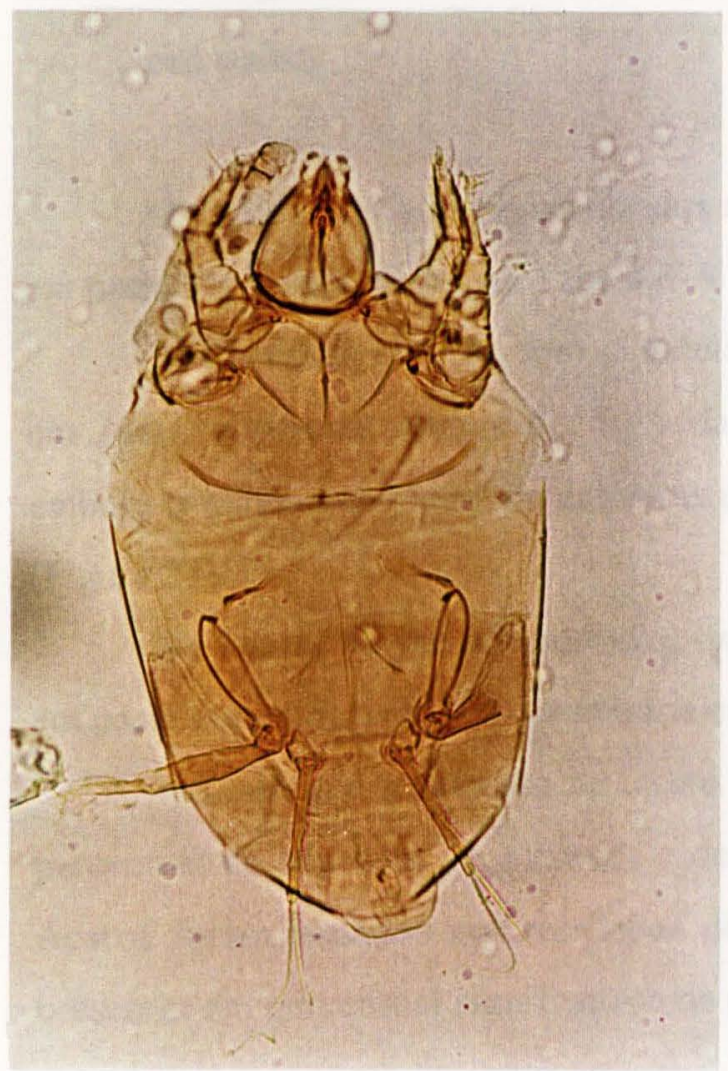

C

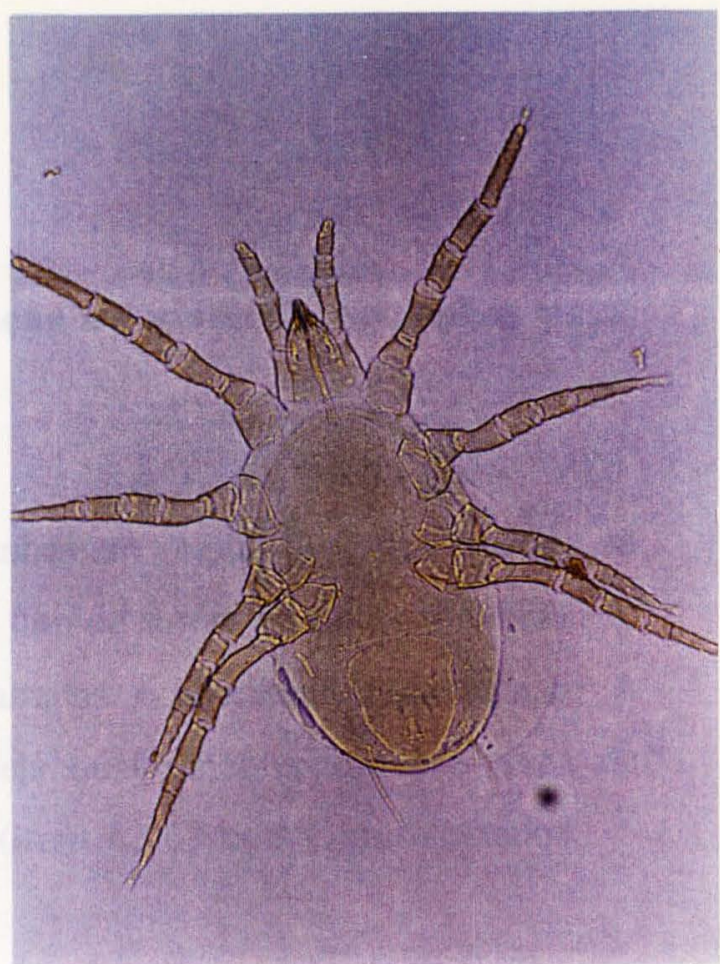

B

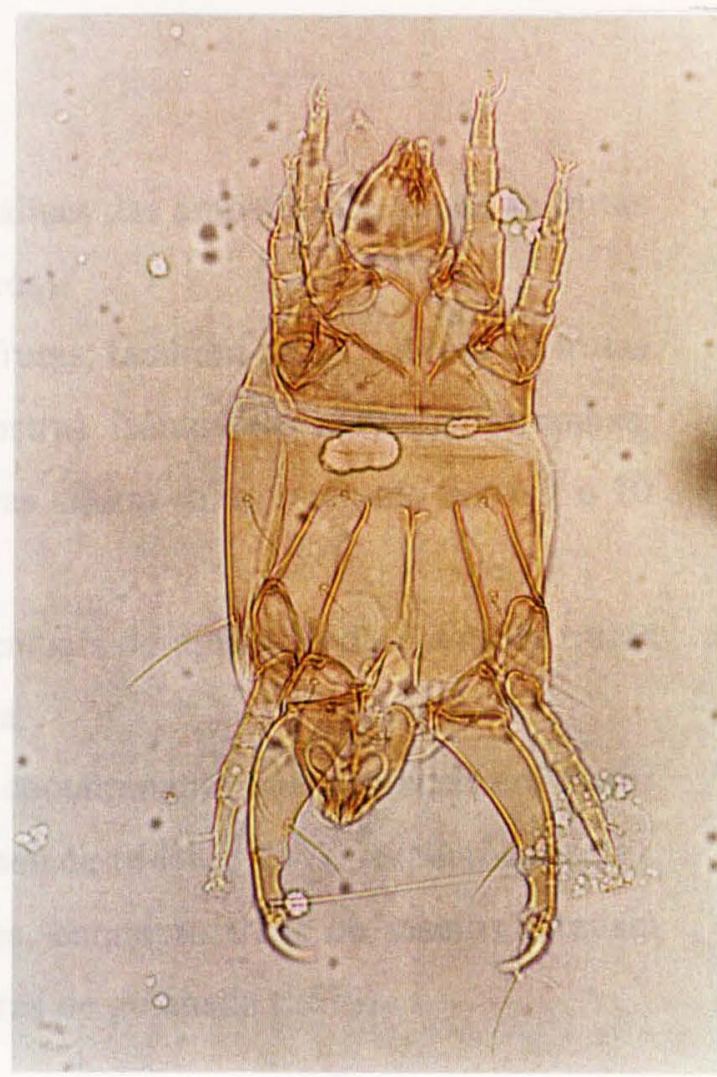

D

Figura 26. Matérias estranhas (ácaros) encontradas em geléias de frutas. A: Oribatidae (400x), B: Phytoseidae (400x), C: Tarsonemidae - fềmea (1600x), D: Tarsonemidae - macho (1600x). 


\subsection{DOCES DE FRUTAS EM PASTA}

\subsubsection{Adaptação do método de determinação de matérias estranhas para doces de frutas em pasta}

A adaptação do método de matérias estranhas em geléias de frutas mostrou-se adequada para os doces de frutas em pasta, pelo fato de serem produtos semelhantes, isto é, ambos são constituidos por frutas trituradas e adicionadas de açúcar. A diferença entre eles é a consistência, razão pela qual recomendou-se a etapa de dispersão da amostra em banho-maria aquecido (item 4.3.6), com bons resultados.

\subsubsection{Contagem e identificação de matérias estranhas em doces de frutas em pasta}

Os resultados individuais obtidos nas análises das amostras de doces de frutas em pasta são apresentados na Tabela 8-A (Anexos).

Assim como ocorreu com as geléias de frutas, também para os doces de frutas em pasta obteve-se menos de $50 \%$ das amostras isentas de matérias estranhas, embora o maior percentual de amostras positivas situou-se no intervalo entre 1 e 10 (Figura 27).

$\mathrm{Na}$ Figura 28 são apresentados os percentuais de amostras de doces de frutas em pasta contendo cada tipo de matéria estranha.

Nota-se que fragmento de inseto foi o contaminante que apareceu em maior percentual de amostras de goiabada e de marmelada (64\% e 13\%, respectivamente). Ácaros foram isolados nos três tipos de doces, enquanto ovos de insetos estavam presentes em percentual significativo de amostras de goiabada (25\%). 


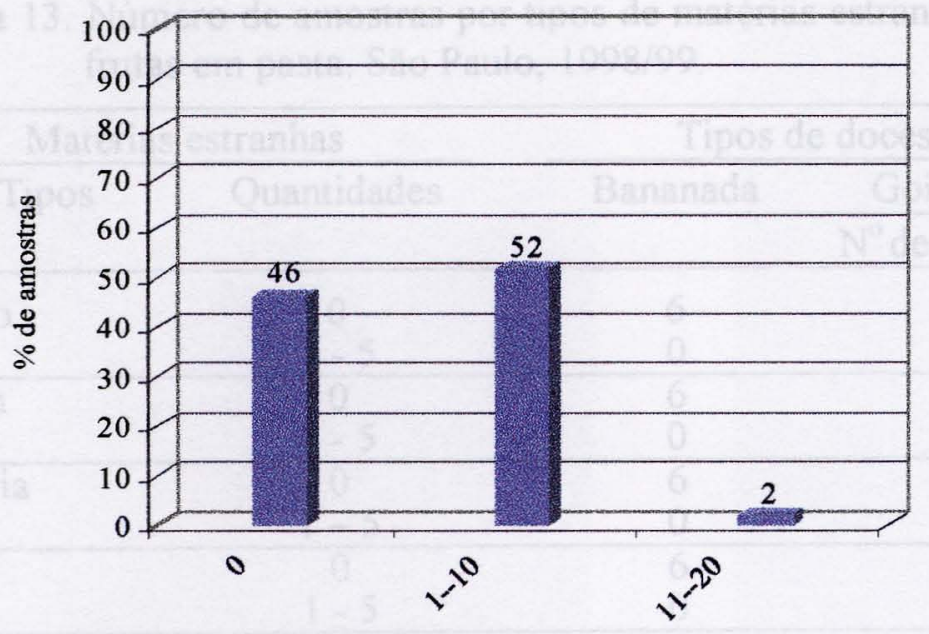

Intervalos de matérias estranhas

Figura 27. Percentuais de amostras de doces de frutas em pasta, quanto à contagem de matérias estranhas. São Paulo, 1998/99.

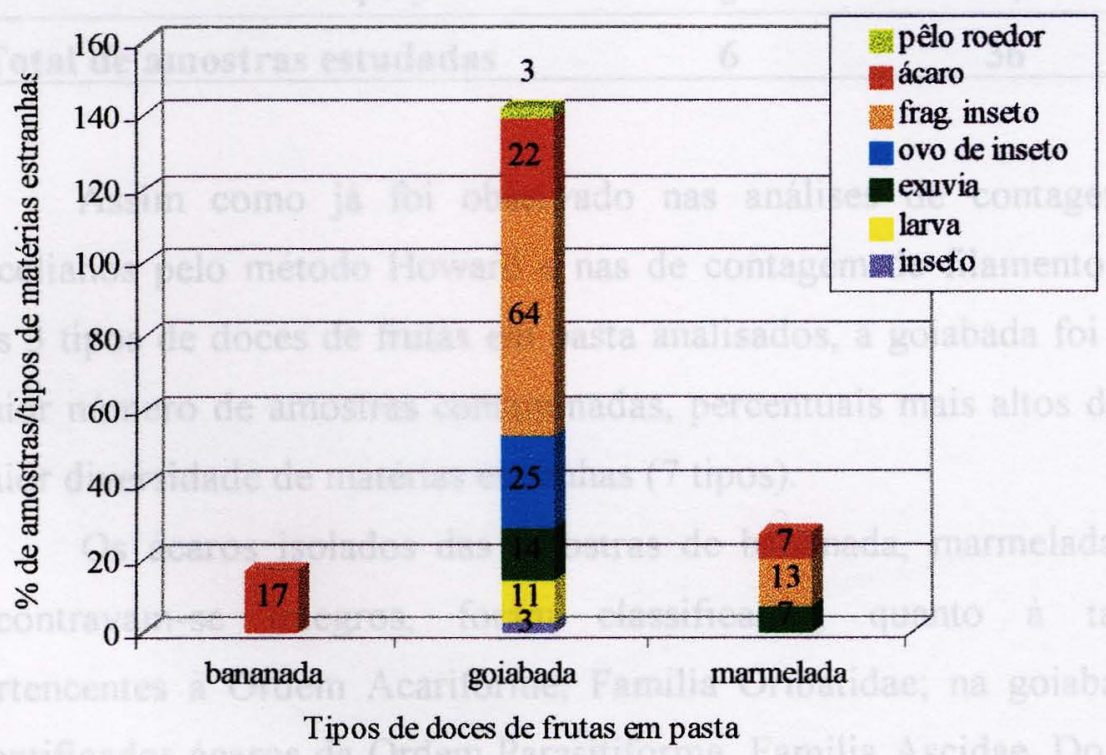

Figura 28. Percentuais de amostras de doces de frutas em pasta por tipos de matérias estranhas. São Paulo, 1998/99.

As matérias estranhas isoladas das amostras de doces de frutas em pasta são apresentadas na Tabela 13; observa-se que fragmentos de insetos foram encontrados em maior número, chegando 1 amostra de goiabada a conter 11 fragmentos (intervalo de 11 a 20). Também foi em 1 amostra de goiabada que apareceu pêlo de roedor. 
Tabela 13. Número de amostras por tipos de matérias estranhas isoladas de doces de frutas em pasta. São Paulo, 1998/99.

\begin{tabular}{|c|c|c|c|c|}
\hline \multicolumn{2}{|c|}{ Matérias estranhas } & \multicolumn{3}{|c|}{ Tipos de doces de frutas em pasta } \\
\hline \multirow[t]{2}{*}{ Tipos } & \multirow[t]{2}{*}{ Quantidades } & Bananada & Goiabada & Marmelada \\
\hline & & \multicolumn{3}{|c|}{$N^{\circ}$ de amostras } \\
\hline \multirow[t]{2}{*}{ Inseto } & 0 & 6 & 35 & 15 \\
\hline & $1-5$ & 0 & 1 & 0 \\
\hline \multirow[t]{2}{*}{ Larva } & 0 & 6 & 32 & 15 \\
\hline & $1-5$ & 0 & 4 & 0 \\
\hline \multirow[t]{2}{*}{ Exuvia } & 0 & 6 & 31 & 14 \\
\hline & $1-5$ & 0 & 5 & 1 \\
\hline \multirow[t]{2}{*}{ Ovo } & 0 & 6 & 27 & 15 \\
\hline & $1-5$ & 0 & 9 & 0 \\
\hline \multirow{4}{*}{$\begin{array}{l}\text { Fragmento de } \\
\text { inseto }\end{array}$} & 0 & 6 & 13 & 13 \\
\hline & $1-5$ & 0 & 19 & 1 \\
\hline & $6-10$ & 0 & 3 & 1 \\
\hline & $11-20$ & 0 & 1 & 0 \\
\hline \multirow[t]{2}{*}{ Acaro } & 0 & 5 & 28 & 14 \\
\hline & $1-5$ & 1 & 8 & 1 \\
\hline \multirow[t]{2}{*}{ Pêlo de roedor } & 0 & 6 & 35 & 15 \\
\hline & $1-5$ & 0 & 1 & 0 \\
\hline \multicolumn{2}{|c|}{ Total de amostras estudadas } & 6 & 36 & 15 \\
\hline
\end{tabular}

Assim como já foi observado nas análises de contagem de filamentos micelianos pelo método Howard e nas de contagem de filamentos de Geotrichum, dos 3 tipos de doces de frutas em pasta analisados, a goiabada foi o que apresentou maior número de amostras contaminadas, percentuais mais altos de contaminação e maior diversidade de matérias estranhas ( 7 tipos).

Os ácaros isolados das amostras de bananada, marmelada e goiabada que encontravam-se integros, foram classificados, quanto à taxonomia, como pertencentes à Ordem Acariforme, Família Oribatidae; na goiabada, ainda, foram identificados ácaros da Ordem Parasitiforme, Família Ascidae. Do total de amostras analisadas, somente em uma foi encontrado inseto, o qual, por estar deformado, não foi possivel classificar.

Entre os produtos com niveis de tolerância estabelecidos no DAL (CENTER FOR FOOD SAFETY AND APPLIED NUTRITION 1989), para frutas em pasta só está prevista a pasta de figo, para a qual é permitido até 13 cabeças de insetos/100 $\mathrm{g}$ de amostra.

Na Figura 29 são apresentadas fotomicrografias de matéria estranhas isoladas de amostras de doces de frutas em pasta. 


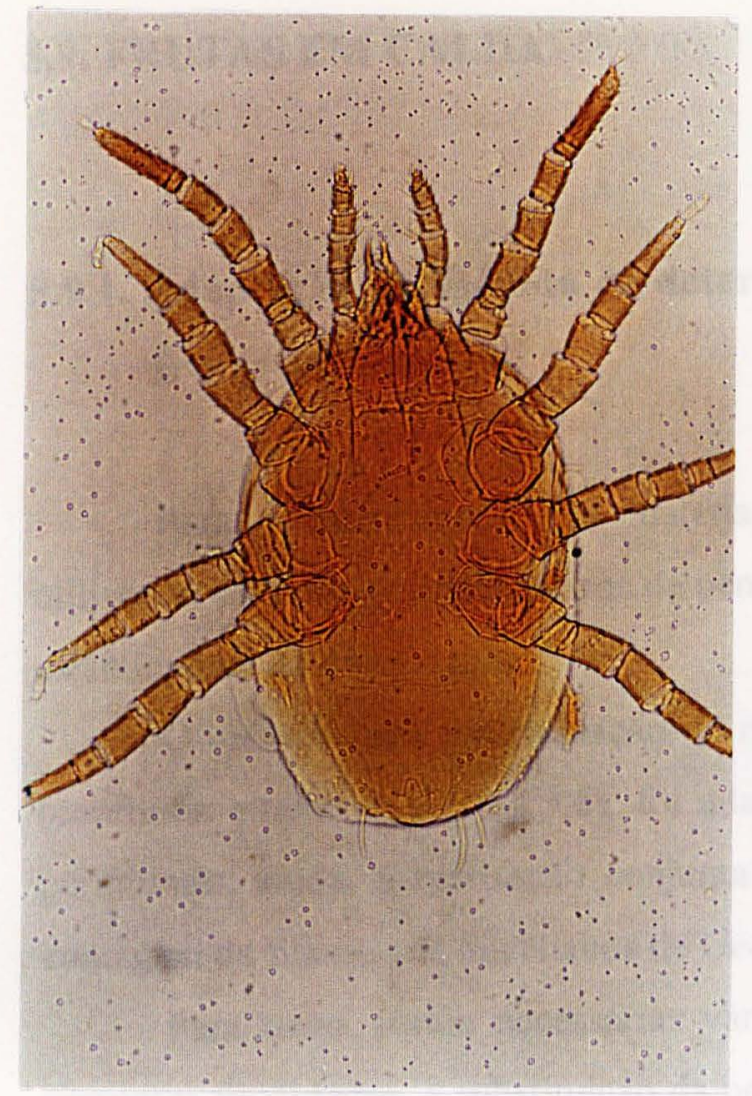

A

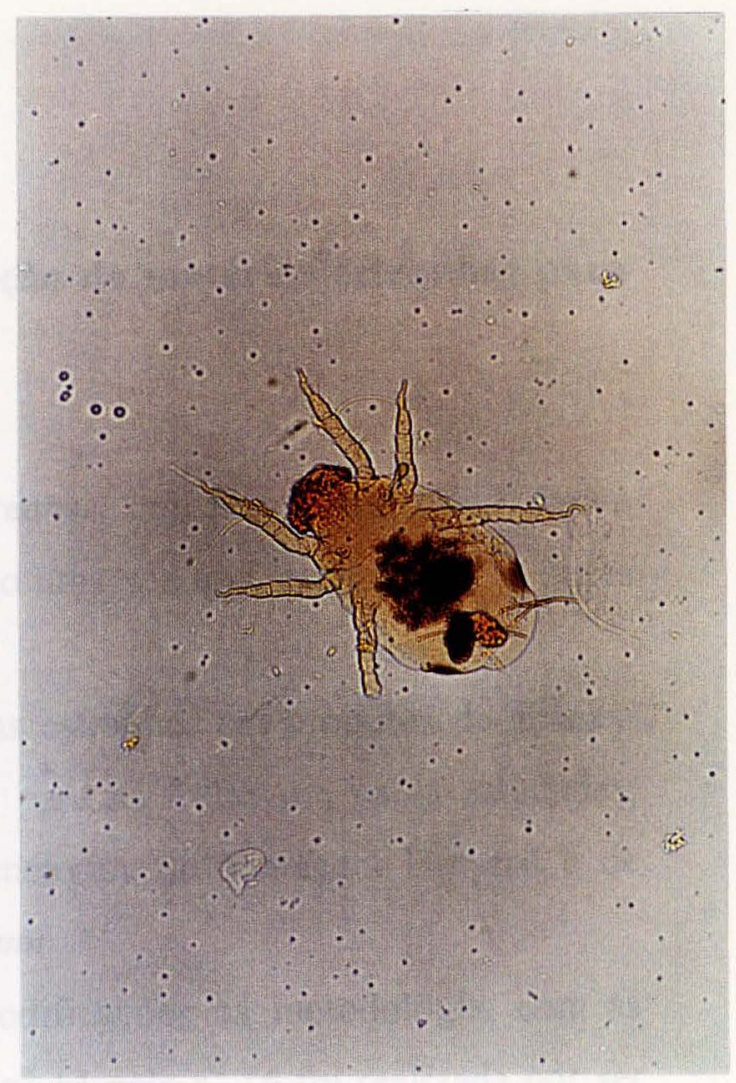

B

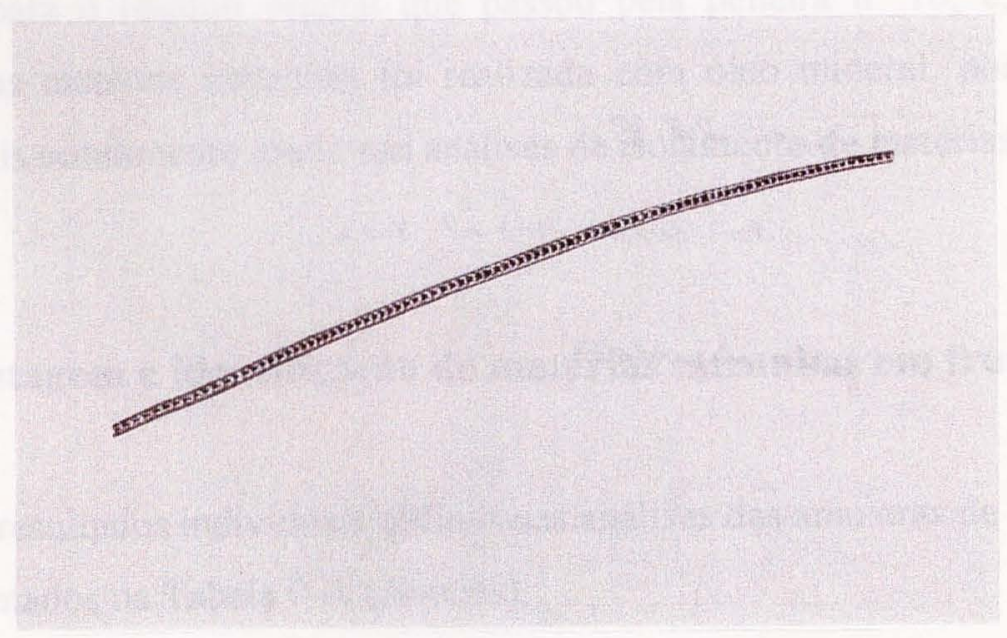

C

Figura 29. Matérias estranhas encontradas em doces de frutas em pasta. A: Ascidae (400x), B: larva hexópoda de ácaro (400x), C: pêlo de roedor (400x). 


\subsection{FRUTAS EM CALDA}

\subsubsection{Adaptação do método de determinação de matérias estranhas para frutas em calda}

Para a determinação de matérias estranhas em frutas em calda foram utilizados métodos macroanalíticos de peneiração uma vez que, no produto, as frutas estão inteiras ou em pedaços.

O método para determinação de matérias estranhas em produtos de abacaxi (conforme citado no item 4.3.6), foi adaptado para as frutas em calda estudadas, permitindo, ainda, a realização conjunta dos métodos de contagem Howard e de contagem de filamentos micelianos de Geotrichum.

Para tanto, foram necessárias várias modificações na metodologia, com as seguintes finalidades: a substituição da peneira $n^{\circ} 14$ pela $n^{\circ} 16$ foi realizada por ser aquela utilizada na técnica de contagem de Geotrichum; a utilização da peneira $\mathrm{n}^{\circ}$ 230 , em substituição à 140 , foi necessária para retenção de fragmentos de insetos; a capacidade do frasco armadilha de $1000 \mathrm{~mL}$, em substituição ao de $2000 \mathrm{~mL}$, foi suficiente para o resíduo vegetal que passou pela peneira $n^{0} 16$; e, finalmente, a extração das matérias estranhas foi realizada com óleo mineral, por ser o líquido extrator mais comumente usado nas análises de isolamento de matérias estranhas.

\subsubsection{Contagem e identificação de matérias estranhas em frutas em calda}

Os resultados individuais obtidos nas análises das amostras de frutas em calda são apresentados na Tabela 9-A (Anexos).

Observa-se na Figura 30 que $67 \%$ das amostras de frutas em calda estavam isentas de matérias estranhas; no entanto, encontraram-se amostras com até 243 contaminantes.

$\mathrm{Na}$ Figura 31 verifica-se que as amostras de doces em calda de ameixa e de figo apresentaram os 7 tipos de matérias estranhas encontrados, observando-se o alto 
percentual de amostras de ameixa contendo larva (48\%) e ácaro (33\%), e amostras de figo contendo inseto ( $52 \%)$.

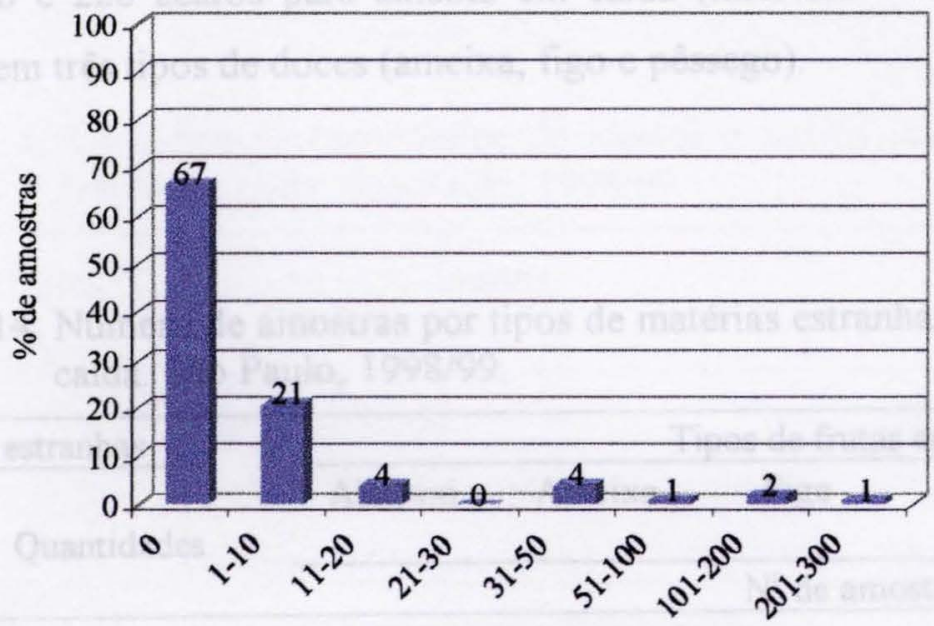

Intervalos de matérias estranhas

Figura 30. Percentuais de amostras de frutas em calda, quanto à contagem de matérias estranhas. São Paulo, 1998/99.

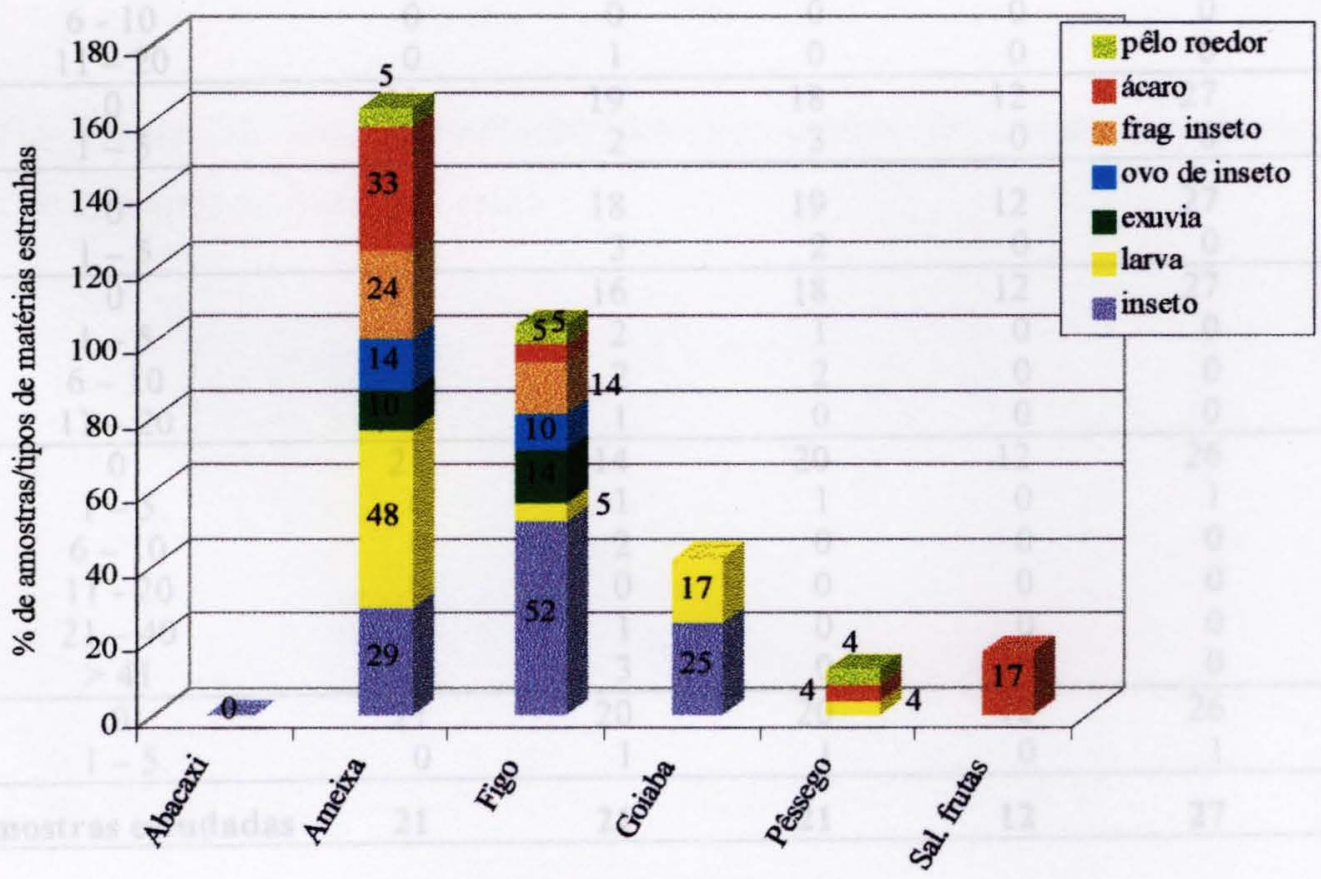

Tipos de frutas em calda

Figura 31. Percentuais de amostras de frutas em calda, por tipos de matérias estranhas. São Paulo, 1998/99. 
$\mathrm{Na}$ Tabela 14 estão representados os tipos e quantidades (por intervalos) de matérias estranhas encontradas nas amostras; insetos e ácaros foram encontrados em grande número em algumas amostras, respectivamente, com valores máximos de 109 para figo e 226 ácaros para ameixa em calda (intervalo $>41$ ). Pêlo de roedor foi isolado em três tipos de doces (ameixa, figo e pêssego).

Tabela 14. Número de amostras por tipos de matérias estranhas isoladas de frutas em calda. São Paulo, 1998/99.

\begin{tabular}{|c|c|c|c|c|c|c|c|}
\hline \multicolumn{2}{|c|}{ Matérias estranhas } & \multicolumn{6}{|c|}{ Tipos de frutas em calda } \\
\hline \multirow[t]{2}{*}{ Tipos } & \multirow[t]{2}{*}{ Quantidades } & Abacaxi & Ameixa & Figo & Goiaba & Pêssego & $\begin{array}{l}\text { Salada } \\
\text { frutas }\end{array}$ \\
\hline & & \multicolumn{6}{|c|}{$\mathrm{N}^{\circ}$ de amostras } \\
\hline \multirow[t]{6}{*}{ Inseto } & 0 & 21 & 15 & 10 & 9 & 27 & 12 \\
\hline & $1-5$ & 0 & 6 & 4 & 3 & 0 & 0 \\
\hline & $6-10$ & 0 & 0 & 1 & 0 & 0 & 0 \\
\hline & $11-20$ & 0 & 0 & 2 & 0 & 0 & 0 \\
\hline & $21-40$ & 0 & 0 & 3 & 0 & 0 & 0 \\
\hline & $>41$ & 0 & 0 & 1 & 0 & 0 & 0 \\
\hline \multirow[t]{4}{*}{ Larva } & 0 & 21 & 11 & 20 & 10 & 26 & 12 \\
\hline & $1-5$ & 0 & 9 & 1 & 2 & 1 & 0 \\
\hline & $6-10$ & 0 & 0 & 0 & 0 & 0 & 0 \\
\hline & $11-20$ & 0 & 1 & 0 & 0 & 0 & 0 \\
\hline \multirow[t]{2}{*}{ Exuvia } & 0 & 21 & 19 & 18 & 12 & 27 & 12 \\
\hline & $1-5$ & 0 & 2 & 3 & 0 & 0 & 0 \\
\hline \multirow[t]{2}{*}{ Ovo } & 0 & 21 & 18 & 19 & 12 & 27 & 12 \\
\hline & $1-5$ & 0 & 3 & 2 & 0 & 0 & 0 \\
\hline \multirow{4}{*}{$\begin{array}{l}\text { Fragmento } \\
\text { de inseto }\end{array}$} & 0 & 21 & 16 & 18 & 12 & 27 & 12 \\
\hline & $1-5$ & 0 & 2 & 1 & 0 & 0 & 0 \\
\hline & $6-10$ & 0 & 2 & 2 & 0 & 0 & 0 \\
\hline & $11-20$ & 0 & 1 & 0 & 0 & 0 & 0 \\
\hline \multirow[t]{6}{*}{ Ácaro } & 0 & 21 & 14 & 20 & 12 & 26 & 10 \\
\hline & $1-5$ & 0 & i & 1 & 0 & 1 & 1 \\
\hline & $6-10$ & 0 & 2 & 0 & 0 & 0 & 0 \\
\hline & $11-20$ & 0 & 0 & 0 & 0 & 0 & 1 \\
\hline & $21-40$ & 0 & 1 & 0 & 0 & 0 & 0 \\
\hline & $>41$ & 0 & 3 & 0 & 0 & 0 & 0 \\
\hline \multirow{2}{*}{$\begin{array}{l}\text { Pêlo de } \\
\text { roedor }\end{array}$} & 0 & 21 & 20 & 20 & 12 & 26 & 12 \\
\hline & $1-5$ & 0 & 1 & 1 & 0 & 1 & 0 \\
\hline \multicolumn{2}{|c|}{ Total de amostras estudad } & 21 & 21 & 21 & 12 & 27 & 12 \\
\hline
\end{tabular}


Os insetos e ácaros passíveis de identificação taxonômica foram relacionados na Tabela 15. Foram classificadas como pertencentes à ordem Coleoptera algumas das larvas isoladas de ameixa em calda.

Tabela 15. Classificação taxonômica de insetos e ácaros isolados de amostras de frutas em calda. São Paulo, 1998/99.

\begin{tabular}{|c|c|c|}
\hline $\begin{array}{c}\text { Tipos de frutas } \\
\text { em calda }\end{array}$ & Insetos & Ácaros \\
\hline Abacaxi & Não encontrado & (Acariforme: Oribatidae) \\
\hline Ameixa & $\begin{array}{l}\text { Cochonilha (Homoptera: Coccoidea) } \\
\text { Formiga (Hymenoptera) }\end{array}$ & $\begin{array}{l}\text { (Acariforme: Acaridae) } \\
\text { (Parasitiforme: Mesostigmata) }\end{array}$ \\
\hline Figo & $\begin{array}{l}\text { Tripes (Thysanoptera:Terebrantia) } \\
\text { Formiga (Hymenoptera) }\end{array}$ & Não encontrado \\
\hline Goiaba & $\begin{array}{l}\text { Tripes (Thysanoptera: Terebrantia) } \\
\text { Abelha (Hymenoptera: Apoidea) }\end{array}$ & Não encontrado \\
\hline Salada de frutas & Não encontrado & (Parasitiforme: Mesostigmata) \\
\hline
\end{tabular}

Na Figura 32 são apresentadas fotomicrografias de matérias estranhas isoladas de amostras de frutas em calda. 


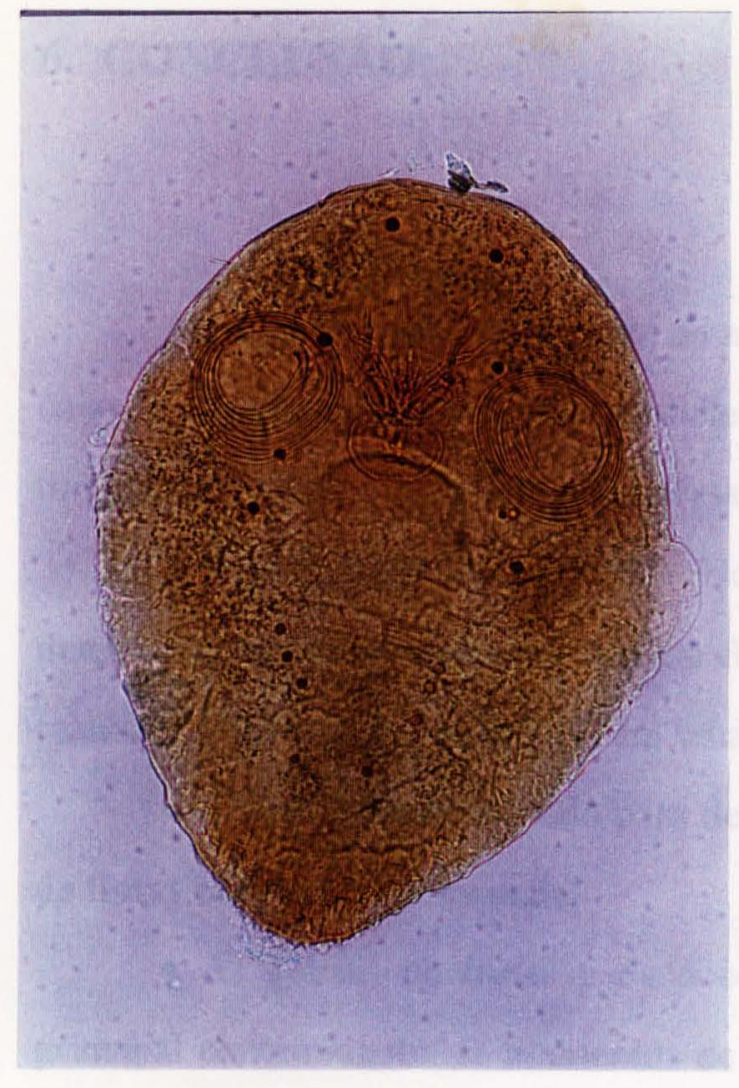

A

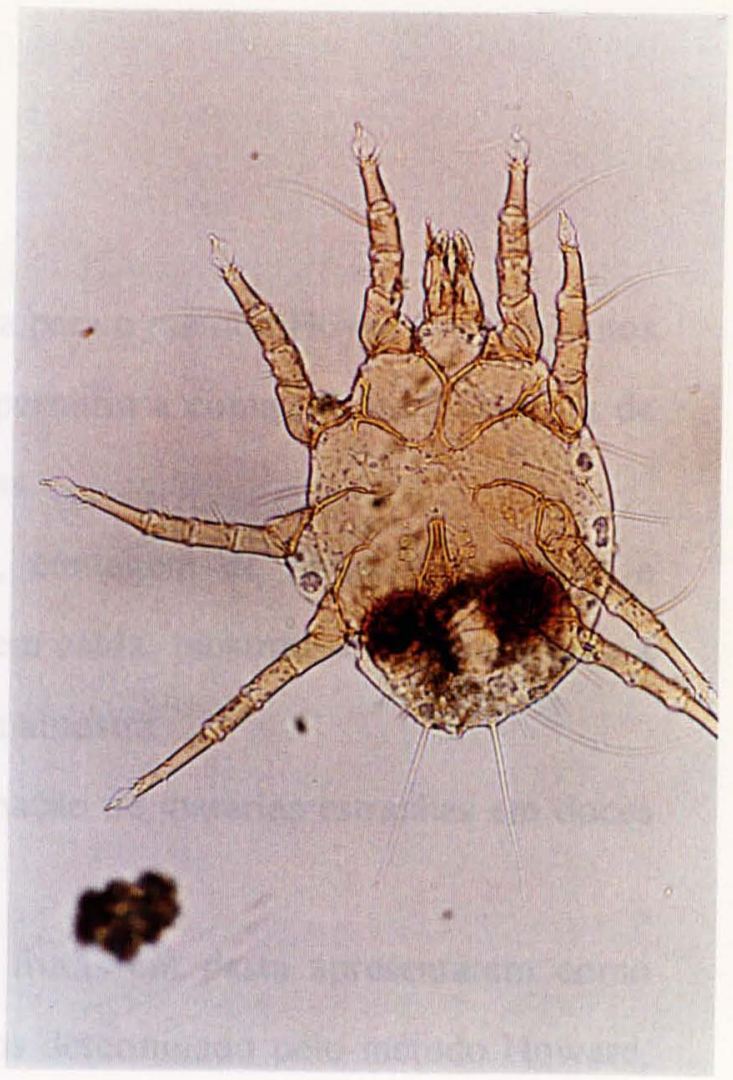

B

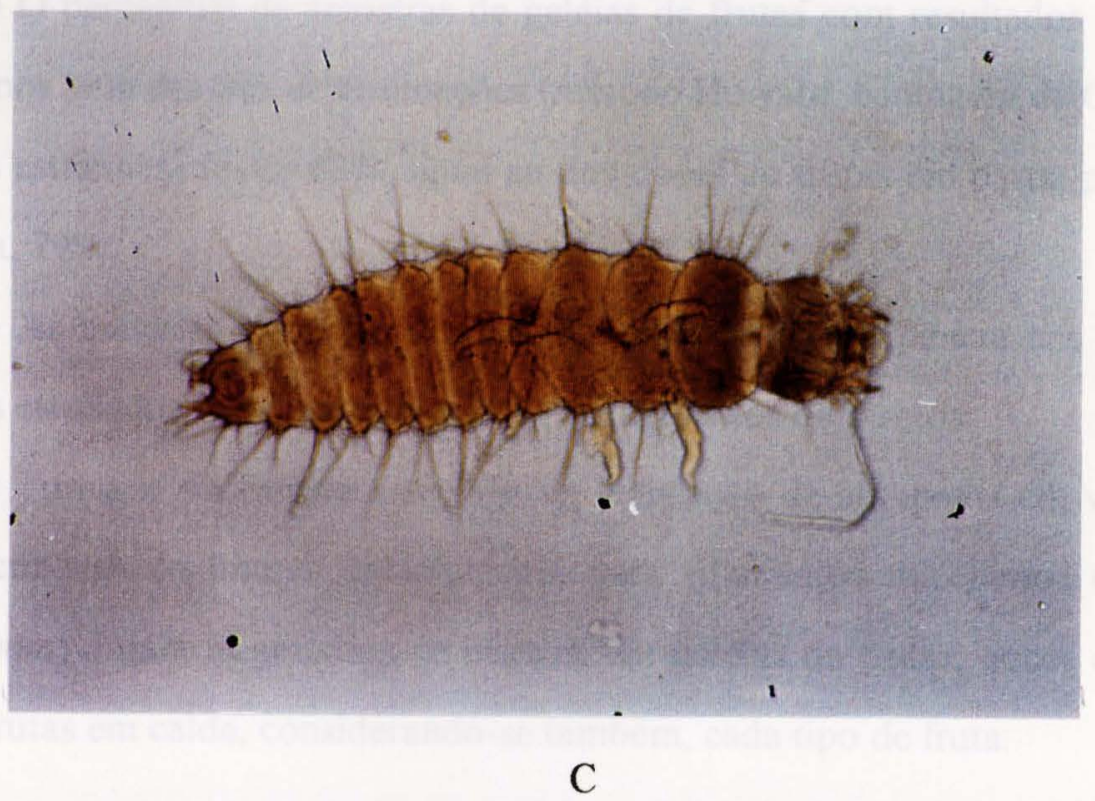

Figura 32. Matérias estranhas encontradas em frutas em calda. A: Coccoidea (800x), B: Acaridae (400x), C:larva de inseto (200x). 


\section{CONCLUSÃo}

- A padronização da diluição da amostra para o método Howard nos produtos cujas frutas não tinham diluição estabelecida, permitiu a contagem de filamentos de fungos em geléias e doces em pasta dessas frutas.

- A adaptação dos métodos Howard, contagem de fungo Geotrichum e determinação de matérias estranhas em frutas em calda, mostrou-se adequada para a realização das três determinações em uma única amostra.

- A adaptação do método para determinação de matérias estranhas em doces de frutas em pasta foi adequada.

- As geléias de frutas e os doces de frutas em pasta apresentaram como principal contaminante, os filamentos de fungos determinado pelo método Howard, seguido pelas matérias estranhas em percentual significativo de amostras.

- As frutas em calda apresentaram principalmente filamentos micelianos, inclusive de Geotrichum.

- O percentual de amostras de geléias de frutas com resultados positivos em pelo menos uma das três determinações (método Howard, contagem de Geotrichum e matérias estranhas) foi de $83 \%$, igual ao dos doces de frutas em pasta; para as frutas em calda, $79 \%$.

- As matérias estranhas encontradas com maior freqüência nos três tipos de produtos estudados foram insetos, ácaros e fragmentos de insetos.

- Torna-se necessária a revisão da legislação de alimentos em vigor, com o estabelecimento de limites de tolerância para filamentos micelianos (exceto para Geotrichum) e para fragmentos de insetos, em geléias de frutas, doces de frutas em pasta e frutas em calda, considerando-se também, cada tipo de fruta. 


\section{REFERÊNCIAS BIBLIOGRÁFICAS}

Amaro AA. Aspectos mercadológicos de frutas industrializadas. IBRAF Acontece 1997; 16: 1-3.

Baggio D. Ácaros de importância médica e econômica. São Paulo: Instituto Ciências Biomédicas-USP; sd.

Bandler R, Gecan JS, Atkinson JC. Mold in fruit nectars and infant fruit purees. J Food Protection 1982; 45: 643-35.

Bandler R, Brickey PM, Cichowicz SM, Gecan JS, Mislivee PB. Effects of processing equipment on Howard mold and rot fragment counts of tomato catsup. $\mathbf{J}$ Food Protection 1987; 50: 28-37.

Barbieri MK. Metodologia para avaliação de materiais estranhos em alimentos. Campinas: Instituto de Tecnologia de Alimentos, 1987.

Battilani P, Chiusa G, Trevisan M, Ghebbioni C. Methods for microbiological quality evaluation of tomato fruits. Riv Scienza Alimentaz 1995; 24: 555-63.

Battilani P, Chiusa G, Cervi C, Trevisan M, Ghebbioni C. Fungal growth and ergosterol content in tomato fruits infected by fungi. Ital J Food Sci 1996; 4: 283-9.

Berbari SAG, Menegale LLC, Almeida ME. Processamento e controle de qualidade de frutas cristalizadas. Higiene Alimentar 1992; 24: 28-36.

Bertoni P, Ghiretti GP, Saudei L, Strina F, Leoni C. Ergosterol content of commercial tomato products as an index of raw material fungal contamination: a proposal of a tolerance value. Ind Conserve 1994; 69: 18-25. 
Beuchat LR. Spoilage of acid products by heat-resistant molds. Dairy Food Environ Sanit 1998; 18: 588-93.

Bishop RH, Duncan CL, Evancho GM. Estimation of fungal contamination in tomato products by a chemical assay for chitin. J Food Science 1982; 47: 437-40.

Blanco C, Quiralte J, Castillo R et al. Anaphylaxis after ingestion of wheat flour contaminated with mites. J Allergy Clin Immunol 1997; 99: 308-13.

Boese J, Cichowicz SM. Extraneous materials: isolation. In: Cunniff P, editor. Official methods of analysis of Association of Official Analytical Chemists International. $16^{\text {th }}$ ed. Arlington: AOAC International, 1995. v. 1. Chapter 16.

Bononi VLR, organizador. Zigomicetos, basidiomicetos e deuteromicetos: noções básicas de taxonomia e aplicações biotecnológicas. São Paulo: Instituto de Botânica, Secretaria de Estado do Meio Ambiente; 1998.

Borges AL, Souza AS, Oliveira AMG, Alves EJ, Dantas JLL, Oliveira MA, et al. A cultura da banana. Brasília (DF): EMBRAPA - SPI; 1994. (Coleção Plantar, 16).

Borror DJ, Delong DM. Introdução ao estudo dos insetos. São Paulo: Edgard Blucher; 1988 .

Brasil. Resolução Normativa da Comissão Nacional de Normas e Padrões para Alimentos $n^{\circ} 12$ de 23.7.1978a. Aprova as seguintes normas técnicas especiais do Estado de São Paulo, revisadas pela CNNPA, relativas a alimentos (e bebidas) para efeito em todo o território brasileiro. Diário Oficial da República Federativa do Brasil, Brasília, 24 jul. 1978. Seção I, pt. 1, p. 11.499-526.

Brasil. Resolução Normativa da Câmara Técnica de Alimentos nº 09 de out.1978b. Atualiza a Resolução $n^{\circ} 52 / 77$ da CNNPA. Diário Oficial da República Federativa do Brasil, Brasília, 11 dez. 1978. Seção I, pt. 1, p. 19.825-7. 
Brasil. Resolução Normativa da Câmara Técnica de Alimentos n 15 de nov. 1978c. Estabelece normas que têm por objetivo fixar a identidade e características mínimas de qualidade a que devem obedecer as geléias de frutas. Diário Oficial da República Federativa do Brasil, Brasília, 01 març. 1979. Seção I, pt. 1, p. 2.929-31.

Brasil. Lei $n^{\circ} 8.078$ de 11.9.1990. Dispõe sobre a proteção do consumidor e dá outras providências. Diário Oficial da República Federativa do Brasil, Brasilia, 12 set. 1990. Suplemento ao ${ }^{\circ} 176$, p. 1-12.

Brasil. Portaria $n^{\circ} 1.428$ de 26.11.1993. Aprova, na forma dos textos anexos, o Regulamento Técnico para Inspeção Sanitária de Alimentos, as Diretrizes para o Estabelecimento de Boas Práticas de Produção... Diário Oficial da República Federativa do Brasil, Brasília, 2 dez. 1993. Seção I, p. 18.415-9.

Brasil. Portaria $n^{\circ} 451$ de 19.9.1997. Aprova o regulamento técnico e princípios gerais para o estabelecimento de critérios e padrões microbiológicos para alimentos... Diário Oficial da República Federativa do Brasil, Brasília, 2 jul. 1998. Seção I, p. 4-13.

Bussab WO, Morettin PA. Estatística básica. 4ª ed., São Paulo: Atual; 1990.

Carvalho Neto C. Manual prático de biologia e controle de roedores. São Paulo: CIBA - GEIGY; 1987.

Castro LAS, Nakasu BH, Fortes JF, Cantillano RFF, Freire CJS, Medeiros ARM, et al. A cultura da ameixeira. Brasília (DF): EMBRAPA - SPI; 1994. (Coleção Plantar, 9).

Center for Food Safety and Applied Nutrition. Macroanalytical Procedures Manual. Washington (DC): Food and Drug Administration; 1984. p. V73-5 (FDA Technical Bulletin 5). 
Center for Food Safety and Applied Nutrition. The Food Defect Action Levels. Washington (DC): Food and Drug Administration; 1989.

Cichowicz SM, Eisenberg WV. Collaborative study of the determination of Geotrichum mold in selected canned fruits and vegetables. J AOAC 1974; 57 : 95760.

Cichowicz SM, Bandler R. Determination of Geotrichum mold in comminuted fruits and vegetables: collaborative study. J AOAC 1982; 65: 1.095-6.

Cichowicz SM, Gecan JS, Atkinson JC, Kvenberg JE. Microanalytical quality of tomato products: juice, paste, puree, sauce and soup. J Food Protection 1982; 45: $627-31$.

Cichowicz SM. Report on analytical mycology of foods and drugs. J AOAC 1983; 66: $393-4$.

Cichowicz SM. Analytical mycology. In: Gorhan JR, editor. Principles of food analysis for filth, decomposition and foreign matter. $3^{\text {rd }}$ ed. Washington (DC): FDA; 1993. p. 191-200. (FDA Technical Bulletin $n^{\circ} 1$ ).

Cousin MA, Zeidler CS, Nelson PE. Chemical detection of mold in processed foods. J Food Science 1984; 49: 439-45.

Cousin MA, Dufrenne J, Rombouts FM, Notermans S. Immunological detection of Botrytis and Monascus species in food. Food Microbiology 1990; 7: 227-35.

Cousin MA. Chitin as a measure of mold contamination of agricultural commodities and foods. J Food Protection 1996; 59:73-81.

Cunha GAP, Matos AP, Souza LFS, Sanches NF, Reinhardt DHRC, Cabral JRS. A cultura do abacaxi. Brasília (DF): EMBRAPA - SPI; 1994. (Coleção Plantar, 12). 
Decker SJ. Extraneous matter in food processing and storage. Dairy Food Environ Sanit $1994 ; 14: 12-5$.

Eiroa MNB. Microrganismos deteriorantes de sucos de frutas e medidas de controle. Bol SBCTA $1989 ; 23: 141-60$.

Eisenberg WV, Cichowicz SM. Machinery mold - indicator organism in food. Food Technol 1977; 31: 52-6.

Eisenberg WV. Sources of food contaminants. In: Gorhan JR, editor. Principles of food analysis for filth, decomposition and foreign matter. $3^{\text {rd }}$ ed. Washington (DC): FDA; 1993. p. 11-25. (FDA Technical Bulletin ${ }^{\circ} 1$ ).

Fancelli M, Mesquita ALM. Pragas da bananeira. In: Braga Sobrinho R, Cardoso JE, Freire FCO editores. Pragas de fruteiras tropicais de importância agroindustrial. Brasilia (DF): EMBRAPA - SPI; 1998. p. 41-51.

Fehlhaber $\mathrm{K}$, Janetschke $\mathrm{P}$. Higiene veterinaria de los alimentos. Zaragoza: Acribia; 1992.

Flechtmann $\mathrm{CHW}$. Ácaros em produtos armazenados e na poeira domiciliar. Piracicaba: Fundação de Estudos Agrários Luiz de Queiroz, 1986.

Franco BDGM, Landgraf M. Microbiologia dos alimentos. São Paulo: Atheneu, 1996.

Frazier WC, Westhoff DC. Microbiología de los alimentos. $4^{\mathrm{a}}$ ed. Zaragoza: Acribia, 1993.

Gallo D, Nakano O, Silveira Neto S, Carvalho RPL, Batista GC, Berti Filho E, et al. Manual de entomologia agrícola. São Paulo: Ceres; 1988. 
Gherardi S, Vicini E. Indagine sul contenuto di muffe nei nettari de fruta e nei succhi di pomodoro. Ind Conserve 1981; 56: 241-5.

Gomes RP. Fruticultura Brasileira. São Paulo: Nobel; 1973.

Gonzaga Neto L, Soares JM. A cultura da goiaba. Brasilia (DF): EMBRAPA - SPI; 1995. (Coleção Plantar, 27).

Gorhan JR. The significance for human health of insects in food. Ann Rev Entomol 1979; 24: 209-24.

Gorhan $\mathrm{J}$, editor. Insect and mite pests in food: an illustrated key. Washington (DC): Department of Agriculture; 1987. (Agriculture Handbook Number 655).

Gorhan JR. Filth in foods: implications for health. In: Gorhan JR, editor. Principles of food analysis for filth, decomposition and foreign matter. $3^{\text {rd }} \mathrm{ed}$. Washington (DC): FDA; 1993. p. 27-32. (FDA Technical Bulletin n ${ }^{\circ} 1$ ).

Goulart R, Carvalho JPP. Presença de filamentos micelianos de fungos em produtos derivados do tomate, vendidos nos supermercados de Florianópolis, SC. Ciênc Tecnol Alim 1983; 3: 169-80.

Gravani RB. Food deterioration and spoilage by insects and rodents. Dairy Food Sanit $1985 ; 5: 138-9$.

Hickel ER. Pragas da videira. In: Braga Sobrinho R, Cardoso JE, Freire FCO editores. Pragas de fruteiras tropicais de importância agroindustrial. Brasilia (DF): EMBRAPA - SPI; 1998. p. 191-209.

Hoffmann FL, Garcia-Cruz CH, Pagnocca FC, Vinturim TM, Mansor AP. Microrganismos contaminantes de polpa de frutas. Ciênc Tecnol Aliment 1997; 17 : 32-7. 
Hughes AM. The mites of stored food and houses. $2^{\text {nd }}$ ed. London: Ministry of Agriculture, Fisheries and Food; 1976. (Technical Bulletin 9).

Insects of Australia: a textbook for students and research workers. $2^{\text {nd }} \mathrm{ed}$. Ithaca: Cornell Un. Pres.; 1990. v.1.

Jackix MH. Industrialização de frutas em calda cristalizadas, geléias e doces em massa. Fundação Tropical de Pesquisas e Tecnologia; 1982. (Série Tecnologia Industrial, v. 12).

Jackix MH. Doces, geléias e frutas em calda: teórico e prático. Campinas: Unicamp; 1988.

Jackson WB. Pest bird ecology and management. In: Gorhan JR, editor. Ecology and management of food-industry pests. Arlington: Association of Official Analytical Chemists; 1991. p. 229-36. (FDA Technical Bulletin n 4).

Jay JM. Microbiologia moderna de los alimentos. $3^{\text {a }}$ ed. Zaragoza: Acríbia, 1994.

Jarvis B. A chemical method for the estimation of mold in tomato products. J Food Technol 1977; 12: 581-91.

Krantz GW. A manual of acarology. $2^{\text {nd }}$ ed. Corvallis: Oregon State University, 1978.

Kvenberg JE, Eisenberg WV, King AC. Limited collaborative study of an optional method for the isolation of light filth from fig and fruit paste. J AOAC 1975; 58: 443-4.

Lara FM, Boiça Jr. AL, Tanzini MR. Pragas do abacaxizeiro. In: Braga Sobrinho R, Cardoso JE, Freire FCO editores. Pragas de fruteiras tropicais de importância agroindustrial. Brasilia (DF): EMBRAPA - SPI; 1998. p. 17-31. 
Larkin EP. Food contaminants - viruses. J Food Protec 1981;44: 320-5.

Lazzari FA. Umidade: fungos e micotoxinas na qualidade de sementes, grãos e

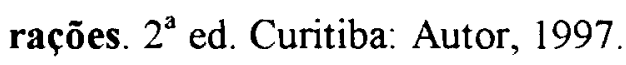

Leitão MFF, Menezes TJB. Estudo comparativo do extrato de tomate enlatado. Coletânea Inst Tecnol Alim 1967/68; 2: 87-102.

Lin $\mathrm{HH}$, Cousin MA. Detection of mold in processed foods by High Performance Liquid Chromatography. J Food Protection 1985; 48: 671-8.

Lin $\mathrm{HH}$, Lister RM, Cousin MA. Enzyme-linked immunosorbent assay for detection of mold in tomato puree. J Food Science 1986; 51: 180-3 e 192.

Lin HH, Cousin MA. Evaluation of enzyme-linked immunosorbent assay for the detection of molds in food. J Food Science 1987; 52: 1089-94.

Matsumoto T, Hisano T, Hamaguchi M, Miike T. Systemic anaphylaxis after eating storage-mite-contaminated food. Int Arch Allergy Immunol 1996; 109: 197-200.

Medina JC. Abacaxi I - cultura. In: Medina JC, Bleinroth EW, De Martin ZJ, Souza Jr AJ, Lara JCC, Hashizume T, et al. Abacaxi - da cultura ao processamento e comercialização. Campinas: ITAL; 1978a. p. 8-68. (Série Frutas Tropicais, 2).

Medina JC. Banana I - cultura. In: Medina JC, Bleinroth EW, De Martin ZJ, Travaglini DA, Okada M, Quast DG, et al. Banana - da cultura ao processamento e comercialização. Campinas: ITAL; 1978b. p. 7-62. (Série Frutas Tropicais, 3).

Medina JC. Goiaba I - cultura. In: Medina JC, Garcia JLM, Kato K, De Martin ZJ, Vieira LF, Renesto OV. Goiaba - da cultura ao processamento e comercialização. Campinas: ITAL; 1978c. p. 7-45. (Série Frutas Tropicais, 6). 
Mislivec PB. Fungi. In: Gorhan JR, editor. Principles of food analysis for filth, decomposition and foreign matter. $3^{\text {rd }}$ ed. Washington (DC): FDA; 1993. p. 35-47. (FDA Technical Bulletin $\left.n^{\circ} 1\right)$.

Olsen AR. Regulatory action criteria for filth and other extraneous materials. II. Alergenic mites: an emerging food safety issue. Regulatory Toxicology Pharmacology 1998a; 28: 190-8.

Olsen AR. Regulatory action criteria for filth and other extraneous materials. III. Review of flies and foodborne enteric disease. Regulatory Toxicology Pharmacology 1998b; 28: 199-211.

Olson NA. The effect of milling on mould counts in tomato products. Food Technol $1980 ; 34: 50-6$.

Patel N, Dawe K, Merret M. The development of an immunochemical method for the detection of mould in tomato paste: an alternative to the Howard mould count. In: Morgan MRA, Smith CJ, Williams PA editors. Food safety and quality assurance application of immunoassay systems. London: Elsevier Applied Science; 1991. p. 326.

Pereira FM, Bortoli SA. Pragas da goiabeira. In: Braga Sobrinho R, Cardoso JE, Freire FCO editores. Pragas de fruteiras tropicais de importância agroindustrial. Brasília (DF): EMBRAPA - SPI; 1998. p. 119-30.

Raseira A, Nakasu BH, Freire CJS, Cantillano FF, Fortes JF, Salles LAB, et al. A cultura do pêssego. Brasília (DF): EMBRAPA - SPI; 1993. (Coleção Plantar, 6).

Robertson A, Patel N, Sargeant JG. Immunofluorescence detection of mould - an aid to the Howard mould counting technique. Food Microbiology 1988; 5: 33-42. 
Samson RA, Hoekstra ES, Frisvad JC, Filtenborg O. Introduction to food-borne fungi. $4^{\text {th }}$ ed. Holanda: Baarn; 1995.

Sanchez-Borges M, Caprilis-Hullet A, Fernandez-Caldas E et al. Mite-contaminated food as a cause of anaphylaxis. J Allergy Clin Immunol 1997; 99 Suppl I: 738-43.

Santos MC, Rodrigues RMMS, Zamboni CQ. Sucos de maracujá, tamarindo e uva: métodos de análise das condições higiênicas. Rev Inst Adolfo Lutz 1990; 50: 23943.

Santos AM. A cultura do morango. Brasília (DF): EMBRAPA - SPI; 1993. (Coleção Plantar, 7).

Santos MC, Rodrigues RMMS, Zamboni CQ. Sucos de maracujá, tamarindo e uva: métodos de análise das condições higiênicas. Rev Inst Adolfo Lutz 1990; 50: 23943.

São Paulo (Estado). Decreto $\mathrm{n}^{\circ} 12.486$ de 20.10.1978. Aprova normas técnicas especiais relativas a alimentos e bebidas. Diário Oficial do Estado de São Paulo, São Paulo, 21 out. 1978, p. 1-42 (NTA 25 e 26).

Silva SD, Leitão MFF, Shipose I, Delazari I, Campos RB. Avaliação físico-química e microbiológica dos concentrados de tomate comerciais. Bol Inst Tecnol Aliment $1975 ; 41: 69-88$.

Simão S. Manual de fruticultura. São Paulo: Ceres; 1971.

Sinha RN. Storage ecosystems. In: Gorhan JR, editor. Ecology and management of food-industry pests. Arlington: Association of Official Analytical Chemists; 1991. p. 17-30. (FDA Technical Bulletin $\mathrm{n}^{\circ} 4$ ). 
Stasny JT, Albright FR, Graham R. Identification of foreign matter in foods. Scan Electron Microsc 1981; 3: 599-610.

Taniwaki MH. Meios de cultura para contagem de fungos em alimentos. Bol SBCTA $1996 ; 30: 132-41$.

Taylor, RB. Introducción al procesado de las frutas. In: Artley D, Ashurst PR, editores. Procesado de frutas. Zaragoza: Acribia; 1997. p. 1-19.

Tosello A, Zangelmi ACB, Yokoya $\mathrm{F}$, et al. Industrialização de frutas. Mundo Agrícola; 1: 115-38, 1975.

Tournas V. Heat-resistant fungi of importance to the food and beverage industry. Critical Rev Microbiol 1994; 20:243-63.

Troller JA. Sanitation in food processing. $2^{\text {nd }}$ ed. London: Academic Press; 1993.

Vasquez AW. Structure and identification of common food - contaminating hairs. J AOAC 1961; 44: 754-79.

Vasquez AW. Information on microscopes and their use. In: Gorhan JR editor. Training manual for analytical entomology in the food industry. Washington (DC): FDA; 1977a. p. 4-16. (FDA Technical Bulletin 2).

Vasquez AW. Basic insect morphology. In: Gorhan JR editor. Training manual for analytical entomology in the food industry. Washington (DC): FDA; 1977b. p. $17-$ 24. (FDA Technical Bulletin 2).

Vasquez AW. Recognition of insect fragments. In: Gorhan JR editor. Training manual for analytical entomology in the food industry. Washington (DC): FDA; 1977c. p. 48-52. (FDA Technical Bulletin 2). 
Vasquez AW. Hair stucture and identification. In: Gorhan JR editor. Training manual for analytical entomology in the food industry. Washington (DC): FDA; 1977d. p. 70-5. (FDA Technical Bulletin 2).

Vasquez AW. Hairs. In: Gorhan JR editor. Principles of food analysis for filth, decomposition, and foreign matter. Washington (DC): FDA; 1981, p. 125-70. (FDA Technical Bulletin 2).

Wheeler HH. Filth in fruit paste. J AOAC 1964; 47: 897-901.

Yokoya F. Método Howard para contagem de fungos em produtos industrializados. Campinas: UNICAMP, 1993.

Zamboni CQ, Pacheco JA, Alves HI, Spiteri N, Roriz T. Estudo comparativo de qualidade entre quatro marcas de purês de tomate, através da contagem de filamentos micelianos pelo método Howard. Rev Inst Adolfo Lutz 1980; 40: 23-7.

Zamboni CQ, Barion MIE, Spiteri N. Contagem de filamentos micelianos pelo método Howard em sucos de tomate, maracujá, caju e uva. Rev. Inst. Adolfo Lutz $1981 \mathrm{a} ; 41: 79-82$.

Zamboni CQ, Alves HI, Santos MC. Contagem de filamentos micelianos em doces em pasta de goiaba, marmelo, pêssego e figo, pelo método de Howard. Rev Inst Adolfo Lutz 1981b; 41: 31-5.

Zamboni CQ. Utilização do fungo Geotrichum candidum no controle da industrialização de produtos de frutas. São Paulo; 1986. [Dissertação de Mestrado - Faculdade de Ciências Farmacêuticas da USP]. 
8. ANEXOS 


\section{FLUXOGRAMA 1}

\section{PADRONIZAÇÃo PARA DILUIÇÃo DA AMOSTRA PARA MÉTODO HOWARD GELÉIAS DE FRUTAS E DOCES DE FRUTAS EM PASTA}

Método: AOAC International 1995, técnica 16.18.05/982.33AdB.

\section{Pesar $50 \mathrm{~g}$ de amostra em béquer de $400 \mathrm{~mL}$}

Adicionar $150 \mathrm{~g}$ de água filtrada e mexer com espátula para dispersar a amostra

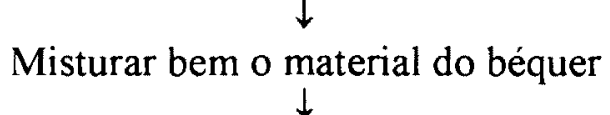

Transferir $40 \mathrm{~mL}$ para tubo cônico de centrífuga graduado, de $50 \mathrm{~mL}$

Centrifugar a $2.200 \mathrm{rpm}$ por $10 \mathrm{~min}$

Decantar o sobrenadante do tubo sem mexer o sedimento

$\downarrow$

Ler o volume do sedimento e diluir com solução a $0,5 \%$ de carboximetilcelulose de acordo com a fruta:

$\downarrow$

1+1: pêssego e damasco

1+3: goiaba

1+6: amora, framboesa e morango

$\downarrow$

Medir $\mathrm{o}^{\circ} \mathrm{Brix}$ em refratômetro 


\section{FLUXOGRAMA 2}

\section{FRUTAS EM CALDA}

Método Howard: MACROANALYTICAL PROCEDURE MANUAL 1984, método 9L4ab e AOAC International 1995, métodos 16.18.03/970.75 e 16.17.01/984.29ABC.

Método para contagem de Geotrichum: AOAC International 1995, métodos 16.19.12/974.34a e 16.19.09/984.30ABC. Método para determinação de matérias estranhas: MACROANALYTICAL PROCEDURE MANUAL 1984, métodos 9L4a. 9L7a.

Pesar a fruta + calda, em béquer, para obter o peso líquido da amostra.

Método Howard para contagem de filamentos micelianos

Transferir $50 \mathrm{~mL}$ da calda para tubo cônico graduado de centrífuga de $50 \mathrm{~mL}$.

Centrifugar a $2.200 \mathrm{rpm}$ por 10 min. Deixar a centrífuga parar espontaneamente e retirar os tubos. Ler o volume do sedimento $\mathrm{e}$ decantar o sobrenadante junto ao restante da amostra.

Adicionar água filtrada até o volume de $10 \mathrm{~mL}, 5 \mathrm{~mL}$ de solução de carboximetilcelulose e agitar o tubo para misturar bem.

Contagem:

Com espátula, colocar quantidade adequada do material homogeneizado no centro da câmara de Howard e cobrir com a lamínula.

Contar 3 montagens de 25 campos cada, em microscópio óptico com aumento de 90 a $125 \mathrm{x}$.

\section{Método para contagem de filamentos micelianos de Geotrichum}

Drenar a amostra em peneira $\mathrm{n}^{\circ} 8 \mathrm{de} 19 \mathrm{~cm}$ de diâmetro, colocada sobre recipiente de vidro. Lavar a amostra com cerca de $300 \mathrm{~mL}$ de água filtrada sobre o recipiente. Reservar a peneira $\mathrm{n}^{\circ} 8 \mathrm{com}$ a amostra para a análise de matérias estranhas. Transferir o líquido para a peneira $\mathrm{n}^{\circ} 16$ colocada sobre a peneira $\mathrm{n}^{\circ} 230$, ambas de $12,7 \mathrm{~cm}$ de diâmetro. Lavar o resíduo das peneiras com água filtrada. Reservar a peneira $\mathrm{n}^{\circ} 16$ para a análise de matérias estranhas. Inclinar e manter a peneira $\mathrm{n}^{\circ} 230$ a $30^{\circ}$ e lavar o resíduo com água filtrada. Transferir o resíduo da peneira para tubo de centrifuga graduado de $50 \mathrm{~mL}$, com uma espátula e um mínimo de água filtrada.

Para volume $\leq 10 \mathrm{~mL}$ : diluir para $10 \mathrm{~mL}$ com água filtrada, adicionar 1 gota de solução de cristal violeta e misturar bem. Adicionar $10 \mathrm{~mL}$ de solução de carboximetilcelulose elevando o volume para $20 \mathrm{~mL}$.

Para volume entre 10 e $30 \mathrm{~mL}$ : diluir para $40 \mathrm{~mL}$ com água filtrada. adicionar 3 gotas de solução de cristal violeta e misturar bem. Centrifugar a $2200 \mathrm{rpm}$ por $6 \mathrm{~min}$. Decantar o sobrenadante. Adicionar água filtrada ao sedimento, próximo a marca de $5 \mathrm{~mL}$. Anotar o volume de sedimento + água. Adicionar igual volume de solução de carboximetilcelulose, misturar e anotar o volume.

Contagem:

Fazer a contagem em lâmina própria. Preparar 2 lâminas pipetando $0,5 \mathrm{ml}$ do material homogeneizado (utilizando pipeta de $1 \mathrm{~mL}$ cortada na marca 0.9 $\mathrm{mL}$ ), espalhar a amostra e cobrir com a lamínula. Contar todos os filamentos de Geotrichum que apresentem pelos menos 3 ramificações características. em microscópio estereoscópico com luz transmitida e aumento de 30 a $45 \mathrm{x}$. Preparar 2 lâminas.

Guardar o material do tubo para a análise de matérias estranhas.

\section{Método para determinação de matérias estranhas}

Juntar à amostra da peneira $\mathrm{n}^{\circ} 8$ colocada sobre o recipiente de vidro (reservada do método de contagem de Geotrichum), água filtrada suficiente para cobri-la. Cortar essa amostra em pequenos pedaços. Anotar a presença de insetos e outras matérias estranhas detectadas macroscopicamente. Transferir o líquido do recipiente de vidro para a peneira $\mathrm{n}^{\circ} 16$ colocada sobre a peneira $\mathrm{n}^{\circ} 230$, ambas de $12,7 \mathrm{~cm}$ de diâmetro. Lavar a amostra sobre as peneiras, com água filtrada. Transferir $\mathrm{o}$ resíduo da peneira $\mathrm{n}^{\circ} 230$ :

. se sobrar pouco resíduo vegetal na peneira: para béquer de $400 \mathrm{~mL}$;

. se sobrar muito resíduo: transferir o material para frasco armadilha de $1000 \mathrm{~mL}$, adicionar $600 \mathrm{~mL}$ de água filtrada, $30 \mathrm{~mL}$ de oleo mineral e agitar com a haste do frasco. Completar o volume com água filtrada. Agitar a cada 5 min durante os primeiros $20 \mathrm{~min}$, deixar em repouso durante $10 \mathrm{~min}$ e extrair a camada oleosa para béquer. Adicionar $20 \mathrm{~mL}$ de óleo mineral ao frasco, completar o volume com água filtrada e agitar com a haste. Deixar em repouso por $10 \mathrm{~min}$ e extrair para o mesmo béquer. Lavar a haste e o gargalo do frasco com água filtrada e coletar no mesmo béquer.

Filtrar a vácuo o material do béquer em papel de filtro riscado.

Filtrar, também, a vácuo em papel de filtro riscado, o material contido no tubo reservado da contagem de Geotrichum (parte final do quadro da direita acima), adicionando sol. de hipoclorito de sódio a 2,5\% para retirar a coloração do cristal violeta.

Contagem: Examinar os papéis de filtro ao microscópio estereoscópico, identificar e contar as matérias estranhas. 


\section{FLUXOGRAMA 3}

\section{GELÉIAS DE FRUTAS}

Método Howard: AOAC International 1995, métodos 16.18.05/982.33AdB e 16.17.01/984.29BC.

Método para contagem de Geotrichum: AOAC International 1995, métodos 16.19.13/982.34AdB e 16.19.09/984.30AB.

Método para determinação de matérias estranhas: AOAC International 1995, método 16.10.06/950.89a.

\section{Preparo da amostra para os métodos de contagem de filamentos micelianos: \\ Homogeneizar a amostra e pesar $50 \mathrm{~g}$ em béquer de $400 \mathrm{~mL}$. \\ Adicionar $150 \mathrm{~g}$ de água filtrada e mexer com bastão de vidro para dispersar a amostra.}

\section{Método Howard para contagem de filamentos micelianos}

Misturar bem o material do béquer e transferir 40 ml para tubo cônico de centrífuga graduado de $50 \mathrm{ml}$. Centrifugar a $2.200 \mathrm{rpm}$ por $10 \mathrm{~min}$. Deixar a centrífuga parar espontaneamente e retirar os tubos.

Decantar o sobrenadante sem mexer o sedimento. Ler o volume do sedimento e diluir com solução de carboximetilcelulose, de acordo com a fruta:

$1+1$ : pêssego e damasco; $1+3$ : goiaba

1+6: amora, framboesa, morango, abacaxi, ameixa, figo e uva

\section{Contagem:}

Com espátula, colocar quantidade adequada de material homogeneizado no centro da câmara de Howard e cobrir com a laminula. Contar 3 montagens de 25 campos cada, em microscópio óptico com aumento de 90 a $125 x$.

Para produtos diluídos $1+1$ dividir $\circ \mathrm{n}^{\circ}$ de campos positivos por 2 , antes de calcular o percentual de fungos.

\section{Método para contagem de filamentos micelianos de Geotrichum}

Misturar bem o material do béquer. Transferir $40 \mathrm{ml}$ p/ tubo cônico de centrífuga graduado de $40 \mathrm{ml}$, adicionar 10 gotas de solução de cristal violeta e misturar bem. Centrifugar $10 \mathrm{~min}$ a $2200 \mathrm{rpm}$. Imediatamente após a parada da centrífuga, retirar os tubos, decantar o sobrenadante e ler o volume do sedimento. Diluir o sedimento na proporção $1+3$ ( $v / v)$ com solução de carboximetilcelulose.

\section{Contagem:}

Fazer a contagem em lâmina própria. Preparar 2 lâminas pipetando $0,5 \mathrm{~mL}$ do material em cada uma (utilizando pipeta de $1 \mathrm{~mL}$ cortada na marca $0,9 \mathrm{~mL}$ ), espalhar a amostra e cobrir com a laminula. Contar todos os filamentos de Geotrichum, que apresentem pelo menos 3 ramificações características, em microscópio estereoscópico, com luz transmitida e aumento de 30 a $45 x$.

\section{Método para determinação de matérias estranhas}

Homogeneizar a amostra e pesar $100 \mathrm{~g}$ em frasco armadilha de $1000 \mathrm{~mL}$. Adicionar $200 \mathrm{~mL}$ de água filtrada a $50^{\circ} \mathrm{C}$ e mexer com a haste do frasco. Adicionar $10 \mathrm{~mL}$ de $\mathrm{HCl}$, mexer, suspender a haste e prendê-la. Ferver o material em chapa aquecedora durante $5 \mathrm{~min}$. Esfriar até a temperatura ambiente. Adicionar $25 \mathrm{~mL}$ de heptano e agitar em agitador magnético, durante $5 \mathrm{~min}$. Completar o volume do frasco com água filtrada e mexer, com a haste, em intervalos de $5 \mathrm{~min}$, durante $20 \mathrm{~min}$. Deixar em repouso $10 \mathrm{~min}$. Extrair em béquer de $400 \mathrm{~mL}$, lavar o gargalo e a haste do frasco com água filtrada e coletar no mesmo béquer. Filtrar a vácuo o material do béquer, sobre papel de filtro riscado.

\section{Contagem:}

Examinar o papel de filtro ao microscópio estereoscópico, com aumento de 30x. Identificar e contar as matérias estranhas. 


\section{FLUXOGRAMA 4}

\section{DOCES DE FRUTAS EM PASTA}

Método Howard: AOAC International 1995, métodos 16.18.05/982.33AdB e 16.17.01/984.29BC.

Método para contagem de Geotrichum: AOAC Intemational 1995, métodos 16.19.13/982.34AdB e 16.19.09/984.30AB.

Método para determinação de matérias estranhas: AOAC International 1995, método 16.10.06/950.89a.

Preparo da amostra para contagem de filamentos micelianos:

Retirar pedaços de diferentes partes da amostra e pesar $50 \mathrm{~g}$, em béquer de $400 \mathrm{~mL}$

Adicionar $150 \mathrm{~g}$ de água filtrada e mexer com espátula para dispersar a amostra.

Método Howard para contagem de filamentos micelianos

Misturar bem o material do béquer e transferir $40 \mathrm{~mL}$ para tubo cônico de centrifuga graduado de $50 \mathrm{~mL}$. Centrifugar a $2.200 \mathrm{rpm}$ por $10 \mathrm{~min}$. Deixar a centrifuga parar espontaneamente e retirar os tubos.

Decantar o sobrenadante sem mexer o sedimento. Ler o volume do sedimento e diluir com solução de carboximetilcelulose na proporção:

$1+4(v / v)$ para banana, marmelo e goiaba.

Contagem:

Com espátula, colocar quantidade adequada do material homogeneizado no centro da câmara de Howard e cobrir com a lamínula. Contar 3 montagens de 25 campos cada, em microscópio óptico com aumento de 90 a $125 x$.

Método para determinação de matérias estranhas

Retirar pedaços de diferentes partes da amostra e pesar $100 \mathrm{~g}$ em frasco armadilha de $1000 \mathrm{~mL}$. Adicionar $200 \mathrm{~mL}$ de água filtrada a $50^{\circ} \mathrm{C}$ e aquecer, em banho-maria, até dispersar a amostra, mexendo com a haste do frasco. Adicionar $10 \mathrm{~mL}$ de $\mathrm{HCl}$, mexer, suspender a haste e prendê-la. Ferver o material em chapa aquecedora durante $5 \mathrm{~min}$. Esfriar até a temperatura ambiente. Adicionar $25 \mathrm{~mL}$ de heptano e agitar em agitador magnético, durante $5 \mathrm{~min}$. Completar o volume do frasco com água filtrada e mexer, com a haste, em intervalos de $5 \mathrm{~min}$, durante $20 \mathrm{~min}$. Deixar em repouso $10 \mathrm{~min}$. Extrair em béquer de $400 \mathrm{~mL}$, lavar o gargalo e a haste do frasco com água filtrada e coletar no mesmo béquer. Filtrar a vácuo o material do béquer, sobre papel de filtro riscado.

\section{Contagem:}

Examinar o papel de filtro ao microscópio estereoscópico, com aumento de 30x.

Identificar e contar as matérias estranhas. 
Tabela 1-A. Resultados individuais das análises de contagem de filamentos micelianos, pelo método Howard, em geléias de frutas. São Paulo, 1998/99.

\begin{tabular}{|c|c|c|c|c|}
\hline \multirow{3}{*}{$\begin{array}{l}\text { Tipos de geléias } \\
\text { de frutas }\end{array}$} & \multirow[t]{3}{*}{ Marcas } & \multicolumn{3}{|c|}{ Filamentos micelianos } \\
\hline & & $\begin{array}{c}\% \text { de campos } \\
\text { positivos }\end{array}$ & $\begin{array}{c}\% \text { de campos } \\
\text { positivos }\end{array}$ & $\begin{array}{c}\% \text { de campos } \\
\text { positivos }\end{array}$ \\
\hline & & $1^{4}$ colheita & 2 colheita & $3^{2}$ colheita \\
\hline abacaxi & A & 2 & 3 & 0 \\
\hline abacaxi & B & 0 & 0 & 0 \\
\hline ameixa & C & 4 & 0 & 5 \\
\hline ameixa & $\mathrm{D}$ & 7 & 9 & 0 \\
\hline amora & $\mathrm{B}$ & 8 & 18 & 7 \\
\hline amora & $\mathrm{I}$ & 18 & 5 & 0 \\
\hline amora & $\mathrm{F}$ & 7 & 2 & 0 \\
\hline amora & $\mathrm{G}$ & 15 & 47 & 14 \\
\hline damasco & B & 0 & 0 & 6 \\
\hline damasco & $\mathbf{F}$ & 2 & 0 & 4 \\
\hline figo & D & 0 & 8 & 11 \\
\hline framboesa & $\mathrm{A}$ & 0 & 0 & 4 \\
\hline framboesa & $\mathrm{F}$ & 0 & 7 & 0 \\
\hline framboesa & $\mathrm{G}$ & 2 & 0 & 2 \\
\hline goiaba & $\mathrm{C}$ & 34 & 83 & 44 \\
\hline goiaba & $E$ & 77 & 59 & 73 \\
\hline goiaba & $\mathrm{A}$ & 19 & 17 & 50 \\
\hline goiaba & $\mathrm{B}$ & 0 & 5 & 16 \\
\hline goiaba & 1 & 47 & 13 & 10 \\
\hline goiaba & $\mathrm{F}$ & 2 & 29 & 12 \\
\hline goiaba & G & 48 & 49 & 34 \\
\hline goiaba & $\mathrm{H}$ & 58 & 18 & 52 \\
\hline morango & $\mathrm{C}$ & 18 & 0 & 0 \\
\hline morango & $\mathrm{E}$ & 19 & 17 & 5 \\
\hline morango & $\mathrm{A}$ & 25 & 6 & 14 \\
\hline morango & B & 2 & 3 & 0 \\
\hline morango & I & 2 & 0 & 0 \\
\hline morango & $\mathrm{F}$ & 2 & 3 & 0 \\
\hline morango & $\mathrm{G}$ & 1 & 1 & 0 \\
\hline morango & $\mathrm{H}$ & 2 & 3 & 8 \\
\hline morango & $\mathrm{D}$ & 4 & 5 & 7 \\
\hline pêssego & $\mathrm{G}$ & 8 & 8 & 5 \\
\hline pêssego & D & 2 & 0 & 3 \\
\hline uva & $\mathrm{C}$ & 0 & 0 & 0 \\
\hline uva & $E$ & 67 & 52 & 46 \\
\hline uva & B & 16 & 4 & 7 \\
\hline uva & $\mathrm{G}$ & 29 & 35 & 17 \\
\hline uva & $\mathrm{H}$ & 41 & 41 & 23 \\
\hline uva & D & 0 & 0 & 0 \\
\hline
\end{tabular}

Os valores representam a média dos resultados das duplicatas. 
Tabela 2-A. Resultados individuais das análises de contagem de filamentos micelianos, pelo método Howard, em doces de frutas em pasta. São Paulo, 1998/99.

\begin{tabular}{|c|c|c|c|c|}
\hline \multirow{3}{*}{$\begin{array}{l}\text { Tipos de doces } \\
\text { de frutas em pasta }\end{array}$} & \multirow[t]{3}{*}{ Marcas } & \multicolumn{3}{|c|}{ Filamentos micelianos } \\
\hline & & $\begin{array}{c}\% \text { de campos } \\
\text { positivos }\end{array}$ & $\begin{array}{c}\text { \% de campos } \\
\text { positivos }\end{array}$ & $\begin{array}{c}\% \text { de campos } \\
\text { positivos }\end{array}$ \\
\hline & & $1^{\mathrm{a}}$ colheita & $2^{2}$ colheita & $3^{a}$ colheita \\
\hline Bananada & E & 0 & 0 & 0 \\
\hline Bananada & $\bar{J}$ & 3 & 0 & 12 \\
\hline Goiabada & $\bar{L}$ & 71 & 76 & $\overline{48}$ \\
\hline Goiabada & M & 93 & 77 & 81 \\
\hline Goiabada & $\mathrm{N}$ & 28 & 17 & 11 \\
\hline Goiabada & $\mathrm{C}$ & 91 & 21 & 65 \\
\hline Goiabada & $\mathrm{E}$ & 67 & 73 & 24 \\
\hline Goiabada & $\mathrm{J}$ & 62 & 9 & 41 \\
\hline Goiabada & 0 & 86 & 85 & 62 \\
\hline Goiabada & $\mathbf{P}$ & 38 & 54 & 33 \\
\hline Goiabada & $\mathbf{Q}$ & 26 & 65 & 34 \\
\hline Goiabada & $\overrightarrow{\mathbf{R}}$ & 77 & 49 & 43 \\
\hline Goiabada & $\bar{S}$ & 96 & 78 & 63 \\
\hline Goiabada & D & 81 & 63 & 58 \\
\hline Marmelada & $\mathrm{L}$ & 24 & 35 & 25 \\
\hline Marmelada & $\mathrm{C}$ & 0 & 2 & 9 \\
\hline Marmelada & $E$ & 8 & 0 & 10 \\
\hline Marmelada & $\mathrm{S}$ & 0 & 0 & 0 \\
\hline Marmelada & D & 0 & 2 & 0 \\
\hline
\end{tabular}


Tabela 3-A. Resultados individuais das análises de contagem de filamentos micelianos, pelo método Howard, em frutas em calda. São Paulo, 1998/99.

\begin{tabular}{|c|c|c|c|c|}
\hline \multirow{2}{*}{$\begin{array}{l}\text { Tipos de frutas } \\
\text { em calda }\end{array}$} & \multirow[t]{2}{*}{ Marcas } & \multicolumn{3}{|c|}{ Filamentos micelianos } \\
\hline & & $\begin{array}{c}\text { \% de campos } \\
\text { positivos } \\
1^{\mathrm{a}} \text { colheita }\end{array}$ & $\begin{array}{c}\% \text { de campos } \\
\text { positivos } \\
2^{2} \text { colheita }\end{array}$ & $\begin{array}{c}\% \text { de campos } \\
\text { positivos } \\
3^{\mathrm{a}} \text { colheita }\end{array}$ \\
\hline Abacaxi & $\mathrm{L}$ & 2 & 1 & 10 \\
\hline Abacaxi & $\mathrm{C}$ & 5 & 1 & 0 \\
\hline Abacaxi & $T$ & 5 & 1 & 3 \\
\hline Abacaxi & $\mathrm{E}$ & 17 & 0 & 0 \\
\hline Abacaxi & $\mathrm{U}$ & 0 & 0 & 0 \\
\hline Abacaxi & $\mathrm{V}$ & 2 & 0 & 0 \\
\hline Abacaxi & D & 0 & 0 & 4 \\
\hline Ameixa & $\mathrm{L}$ & 3 & 0 & 5 \\
\hline Ameixa & $\mathrm{X}$ & 0 & 0 & 0 \\
\hline Ameixa & $\mathrm{C}$ & 0 & 0 & 0 \\
\hline Ameixa & $\mathrm{P}$ & 1 & 0 & 4 \\
\hline Ameixa & $S$ & 3 & 0 & 6 \\
\hline Ameixa & $\bar{Z}$ & 7 & 11 & 0 \\
\hline Ameixa & $\mathrm{D}$ & 1 & 1 & 0 \\
\hline Figo & $\mathrm{L}$ & 0 & 0 & 0 \\
\hline Figo & $\mathrm{N}$ & 3 & 5 & 3 \\
\hline Figo & C & 0 & 0 & 0 \\
\hline Figo & $E$ & 0 & 0 & 0 \\
\hline Figo & $\mathrm{P}$ & 0 & 0 & 0 \\
\hline Figo & $Q$ & 0 & 4 & 7 \\
\hline Figo & $\overrightarrow{\mathrm{D}}$ & 27 & 1 & 0 \\
\hline Goiaba & $\mathrm{L}$ & 3 & 2 & 0 \\
\hline goiaba & $\mathrm{N}$ & 0 & 0 & 0 \\
\hline goiaba & $\mathrm{C}$ & 15 & 1 & 0 \\
\hline goiaba & $\mathrm{S}$ & 0 & 1 & 6 \\
\hline pêssego & $\mathrm{L}$ & 6 & 0 & 14 \\
\hline pêssego & $\mathrm{M}$ & 17 & 6 & 10 \\
\hline pêssego & $\mathrm{C}$ & 0 & 0 & 0 \\
\hline pêssego & $E$ & 7 & 11 & 8 \\
\hline pêssego & W & 9 & 6 & 4 \\
\hline pêssego & $\mathrm{K}$ & 0 & 1 & 0 \\
\hline pêssego & $\mathrm{Y}$ & 1 & 5 & 7 \\
\hline pêssego & $\mathbf{P}$ & 1 & 3 & 0 \\
\hline pêssego & D & 2 & 0 & 0 \\
\hline salada de frutas & $\mathrm{L}$ & 0 & 1 & 3 \\
\hline salada de frutas & $\mathrm{C}$ & 2 & 2 & 5 \\
\hline salada de frutas & $\mathrm{E}$ & 2 & 1 & 4 \\
\hline salada de frutas & $\mathrm{K}$ & 0 & 4 & 0 \\
\hline
\end{tabular}

Os valores representam a média dos resultados das duplicatas. 
Tabela 4-A. Resultados individuais das análises de contagem de filamentos micelianos de Geotrichum em geléias de frutas. São Paulo, 1998/99.

\begin{tabular}{|c|c|c|c|c|}
\hline \multirow{3}{*}{$\begin{array}{l}\text { Tipos de geléias } \\
\text { de frutas }\end{array}$} & \multirow[t]{3}{*}{ Marcas } & \multicolumn{3}{|c|}{ Filamentos de Geotrichum } \\
\hline & & $\begin{array}{l}\text { Filamentos } / 100 \mathrm{~mL} \\
\text { de preparação }\end{array}$ & $\begin{array}{c}\text { Filamentos/100mL } \\
\text { de preparação }\end{array}$ & $\begin{array}{c}\text { Filamentos } / 100 \mathrm{~mL} \\
\text { de preparação }\end{array}$ \\
\hline & & $1^{2}$ colheita & 2 colheita & $3^{\mathrm{a}}$ colheita \\
\hline abacaxi & A & 0 & 0 & 0 \\
\hline abacaxi & B & 0 & 0 & 0 \\
\hline ameixa & $\mathrm{C}$ & 0 & 0 & 0 \\
\hline ameixa & $\mathrm{D}$ & 0 & 0 & 0 \\
\hline amora & B & 0 & 0 & 0 \\
\hline amora & I & 0 & 0 & 0 \\
\hline amora & $\mathrm{F}$ & 0 & 0 & 0 \\
\hline amora & $G$ & 900 & 0 & 2.000 \\
\hline damasco & $\mathrm{B}$ & 0 & 0 & 0 \\
\hline damasco & $\mathrm{F}$ & 0 & 700 & 100 \\
\hline figo & $\mathrm{D}$ & 0 & 0 & 0 \\
\hline framboesa & A & 0 & 0 & 0 \\
\hline framboesa & $\mathrm{F}$ & 0 & 300 & 600 \\
\hline framboesa & $\mathrm{G}$ & 0 & 0 & 0 \\
\hline goiaba & $\mathrm{C}$ & 0 & 0 & 0 \\
\hline goiaba & $E$ & 7.400 & 0 & 0 \\
\hline goiaba & $\mathrm{A}$ & 0 & 0 & 500 \\
\hline goiaba & 3 & 0 & 0 & 0 \\
\hline goiaba & 1 & 2.600 & 600 & 0 \\
\hline goiaba & $\mathrm{F}$ & 0 & 0 & 0 \\
\hline goiaba & $\mathrm{G}$ & 0 & 0 & 1.200 \\
\hline goiaba & $\mathrm{H}$ & 1.000 & 800 & 0 \\
\hline morango & $\mathrm{C}$ & 0 & 0 & 0 \\
\hline morango & $E$ & 2.400 & 0 & 0 \\
\hline morango & A & 8.000 & 1.200 & 0 \\
\hline morango & B & 0 & 0 & 500 \\
\hline morango & $I$ & 100 & 0 & 0 \\
\hline morango & $\mathrm{F}$ & 0 & 0 & 0 \\
\hline morango & $\mathrm{G}$ & 0 & 0 & 0 \\
\hline morango & $\mathrm{H}$ & 1.500 & 900 & 0 \\
\hline morango & D & 0 & 0 & 0 \\
\hline pêssego & $\mathrm{G}$ & 0 & 0 & 0 \\
\hline pêssego & $\mathrm{D}$ & 0 & 0 & 200 \\
\hline uva & $\mathrm{C}$ & 0 & 0 & 0 \\
\hline uva & $E$ & 1.100 & 400 & 600 \\
\hline uva & B & 0 & 0 & 0 \\
\hline uva & $\mathrm{G}$ & 300 & 400 & 0 \\
\hline uva & $\mathrm{H}$ & 0 & 0 & 0 \\
\hline uva & D & 0 & 0 & 0 \\
\hline
\end{tabular}

Os valores representam a média dos resultados das duplicatas. 
Tabela 5-A. Resultados individuais das análises de contagem de filamentos micelianos de Geotrichum em doces de frutas em pasta. São Paulo, 1998/99.

\begin{tabular}{|c|c|c|c|c|}
\hline \multirow{3}{*}{$\begin{array}{l}\text { Tipos de doces } \\
\text { de frutas em pasta }\end{array}$} & \multirow[t]{3}{*}{ Marcas } & \multicolumn{3}{|c|}{ Filamentos de Geotrichum } \\
\hline & & $\begin{array}{c}\text { Filamentos } / 100 \mathrm{~mL} \\
\text { de preparação }\end{array}$ & $\begin{array}{c}\text { Filamentos } / 100 \mathrm{~mL} \\
\text { de preparação }\end{array}$ & $\begin{array}{c}\text { Filamentos } / 100 \mathrm{~mL} \\
\text { de preparação }\end{array}$ \\
\hline & & $1^{2}$ colheita & $2^{2}$ colheita & $3^{2}$ colheita \\
\hline Bananada & $\mathrm{E}$ & 0 & 0 & 0 \\
\hline Bananada & $\mathbf{J}$ & 0 & 0 & 0 \\
\hline Goiabada & $\mathrm{L}$ & 2.100 & 1.300 & 0 \\
\hline Goiabada & $\mathbf{M}$ & 1.800 & 1.400 & 1.400 \\
\hline Goiabada & $\mathrm{N}$ & 1.700 & 0 & 800 \\
\hline Goiabada & $\mathrm{C}$ & 0 & 0 & 0 \\
\hline Goiabada & $E$ & 0 & 0 & 0 \\
\hline Goiabada & $\mathrm{J}$ & 900 & 0 & 0 \\
\hline Goiabada & 0 & 1.100 & 2.300 & 600 \\
\hline Goiabada & $\mathrm{P}$ & 0 & 0 & 0 \\
\hline Goiabada & $\mathbf{Q}$ & 0 & 0 & 1.000 \\
\hline Goiabada & $\mathbf{R}$ & 1.600 & 700 & 0 \\
\hline Goiabada & $\mathrm{S}$ & 1.200 & 0 & 0 \\
\hline Goiabada & $\mathrm{D}$ & 0 & 0 & 0 \\
\hline Marmelada & $\mathbf{L}$ & 1.300 & 800 & 0 \\
\hline Marmelada & $\mathrm{C}$ & 0 & 0 & 0 \\
\hline Marmelada & $\mathrm{E}$ & 0 & 0 & 700 \\
\hline Marmelada & $\mathbf{S}$ & 0 & 0 & 0 \\
\hline Marmelada & $\mathrm{D}$ & 0 & 0 & 0 \\
\hline
\end{tabular}

Os valores representam a média dos resultados das duplicatas. 
Tabela 6-A. Resultados individuais das análises de contagem de filamentos micelianos de Geotrichum em frutas em calda. São Paulo, 1998/99.

\begin{tabular}{|c|c|c|c|c|}
\hline \multirow{3}{*}{$\begin{array}{l}\text { Tipos de frutas } \\
\text { em calda }\end{array}$} & \multirow[t]{3}{*}{ Marcas } & \multicolumn{3}{|c|}{$\begin{array}{l}\text { Filamentos de Geotrichum } \\
\end{array}$} \\
\hline & & $\begin{array}{c}\text { Filamentos } / 100 \mathrm{~g} \\
\text { de amostra }\end{array}$ & $\begin{array}{c}\text { Filamentos } / 100 \mathrm{~g} \\
\text { de amostra }\end{array}$ & $\begin{array}{c}\text { Filamentos } / 100 \mathrm{~g} \\
\text { de amostra }\end{array}$ \\
\hline & & $1^{2}$ colheita & $2^{2}$ colheita & $3^{\text {a }}$ colheita \\
\hline Abacaxi & $\mathbf{L}$ & 0 & 0 & 65 \\
\hline Abacaxi & $\bar{C}$ & 7 & 5 & 0 \\
\hline Abacaxi & $\mathrm{T}$ & 32 & 0 & 14 \\
\hline Abacaxi & $\mathrm{E}$ & 138 & 0 & 3 \\
\hline Abacaxi & $\mathrm{U}$ & 0 & 0 & 0 \\
\hline Abacaxi & $\mathrm{V}$ & 15 & 23 & 24 \\
\hline Abacaxi & $\mathrm{D}$ & 0 & 32 & 13 \\
\hline Ameixa & $\mathrm{L}$ & 2 & 0 & 0 \\
\hline ameixa & $\mathrm{X}$ & 0 & 0 & 0 \\
\hline ameixa & $\mathrm{C}$ & 0 & 0 & 0 \\
\hline ameixa & $\mathrm{P}$ & 3 & 33 & 0 \\
\hline ameixa & $\mathrm{S}$ & 31 & 0 & 47 \\
\hline ameixa & $Z$ & 20 & 0 & 9 \\
\hline ameixa & $\mathrm{D}$ & 14 & 0 & 0 \\
\hline figo & $\mathrm{L}$ & 0 & 0 & 0 \\
\hline figo & $\mathrm{N}$ & 0 & 0 & 0 \\
\hline figo & $\mathrm{C}$ & 0 & 0 & 0 \\
\hline figo & $E$ & 0 & 0 & 0 \\
\hline figo & $\mathrm{P}$ & 2 & 0 & 0 \\
\hline figo & $Q$ & 0 & 28 & 11 \\
\hline figo & D & 9 & 0 & 0 \\
\hline goiaba & $\mathrm{L}$ & 0 & 0 & 0 \\
\hline goiaba & $\mathrm{N}$ & 0 & 0 & 0 \\
\hline goiaba & $\mathrm{C}$ & 0 & 0 & 0 \\
\hline goiaba & $\mathrm{S}$ & 6 & 0 & 13 \\
\hline pêssego & $\mathrm{L}$ & 38 & 0 & 83 \\
\hline pêssego & $\mathrm{M}$ & 392 & 151 & 248 \\
\hline pêssego & $\mathrm{C}$ & 0 & 0 & 0 \\
\hline pêssego & $E$ & 217 & 55 & 45 \\
\hline pêssego & $\mathrm{W}$ & 0 & 146 & 56 \\
\hline pêssego & $\mathrm{K}$ & 0 & 10 & 26 \\
\hline pêssego & $Y$ & 29 & 32 & 23 \\
\hline pêssego & $\mathbf{P}$ & 2 & 17 & 9 \\
\hline pêssego & $\mathrm{D}$ & 39 & 0 & 21 \\
\hline salada de frutas & $\mathrm{L}$ & 9 & 6 & 16 \\
\hline salada de frutas & $\mathrm{C}$ & 19 & 14 & 0 \\
\hline salada de frutas & $\mathrm{E}$ & 5 & 8 & 0 \\
\hline salada de frutas & $\mathrm{K}$ & 0 & 0 & 0 \\
\hline
\end{tabular}

Os valores representam a média dos resultados das duplicatas. 
Tabela 7-A. Resultados individuais das análises de determinação de matérias estranhas em geléias de frutas. São Paulo, 1998/99.

\begin{tabular}{|c|c|c|c|c|}
\hline \multirow{3}{*}{$\begin{array}{l}\text { Tipos de geléias } \\
\text { de frutas }\end{array}$} & \multirow[t]{3}{*}{ Marcas } & \multicolumn{3}{|c|}{ Matérias estranhas } \\
\hline & & Números/tipos & Números/tipos & Números/tipos \\
\hline & & $1^{2}$ colheita & $2^{\mathrm{a}}$ colheita & $3^{a}$ colheita \\
\hline abacaxi & $\mathrm{A}$ & 0 & 0 & 0 \\
\hline abacaxi & B & 0 & 2 insetos & 0 \\
\hline ameixa & $\mathrm{C}$ & 0 & 0 & 0 \\
\hline ameixa & D & 0 & 0 & 0 \\
\hline amora & $\mathrm{B}$ & $\begin{array}{c}3 \text { insetos, } 5 \text { fi, } 1 \text { ácaro, } \\
1 \text { larva }\end{array}$ & $\begin{array}{c}3 \text { insetos, } 2 \text { larvas, } 3 \text { fi, } \\
2 \text { ovos, } 6 \text { ácaros }\end{array}$ & 1 inseto, 6 fi, 2 ácaros \\
\hline amora & $I$ & 3 insetos, $2 \mathrm{fi}, 1$ ácaro & $2 \mathrm{fi}$ & 1 inseto, 2 fi, 2 ácaros \\
\hline amora & $\mathbf{F}$ & 8 insetos, l exuvia, l ácaro & $\begin{array}{c}10 \text { insetos, } 1 \text { exuvia, } \\
1 \text { ácaro }\end{array}$ & $\begin{array}{c}4 \text { insetos, } 1 \text { larva, } \\
2 \text { ácaros }\end{array}$ \\
\hline amora & $\bar{G}$ & 1 inseto, 1 ovo & 6 insetos, 2 ácaros & $\begin{array}{c}6 \text { insetos, } 1 \text { exuvia, } \\
2 \text { ácaros }\end{array}$ \\
\hline damasco & B & 0 & 0 & 0 \\
\hline damasco & $\mathrm{F}$ & 1 pêlo roedor & 0 & $2 \mathrm{fi}$ \\
\hline figo & $\bar{D}$ & $\begin{array}{c}9 \text { insetos, } 1 \text { larva, } \\
1 \text { exuvia, } 2 \mathrm{fi}\end{array}$ & $2 \mathrm{fi}$ & 6 insetos, $3 \mathrm{fi}$ \\
\hline framboesa & A & 0 & 1 exuvia, 2 fi, 6 ácaros & 0 \\
\hline framboesa & $\bar{F}$ & $\begin{array}{l}2 \text { insetos, I larva, I ovo, } \\
\text { I ácaro }\end{array}$ & $\begin{array}{c}5 \text { insetos, lovo, } \\
15 \text { ácaros }\end{array}$ & 3 insetos, 1 ácaro \\
\hline framboesa & G & 2 ovos & 2 ovos & 1 inseto, 2 fi, 1 ácaro \\
\hline goiaba & $\mathrm{C}$ & 0 & 0 & 0 \\
\hline goiaba & $E$ & $2 \mathrm{fi}$ & 0 & 0 \\
\hline goiaba & $\mathrm{A}$ & $17 \mathrm{fi}$ & 0 & $5 \mathrm{fi}$ \\
\hline goiaba & B & 0 & 0 & 0 \\
\hline goiaba & $I$ & 1 larva & 0 & lovo \\
\hline goiaba & $\mathrm{F}$ & $5 \mathrm{fi}$ & $7 \mathrm{fi}$ & $5 \mathrm{fi}$ \\
\hline goiaba & $\mathrm{G}$ & $10 \mathrm{fi}$ & $2 \mathrm{fi}$ & $6 \mathrm{fi}$ \\
\hline goiaba & $\mathrm{H}$ & $1 \mathrm{fi}$ & $1 \mathrm{fi}$ & 0 \\
\hline morango & $\mathrm{C}$ & I larva & 0 & 0 \\
\hline morango & $\mathrm{E}$ & $10 \mathrm{fi}$ & l fi, I larva & 2 fi, 1 ovo, 1 ácaro \\
\hline morango & $\mathrm{A}$ & 0 & 1 larva, $2 \mathrm{fi}$ & $7 \mathrm{fi}$ \\
\hline morango & $\mathbf{B}$ & 0 & 2 insetos & $\begin{array}{c}3 \text { insetos, } 2 \text { larvas, } \\
1 \text { exuvia, } 4 \mathrm{fi}\end{array}$ \\
\hline morango & I & $6 \mathrm{fi}$ & 0 & 0 \\
\hline morango & $\mathrm{F}$ & 0 & 0 & $1 \mathrm{fi}$ \\
\hline morango & $\mathrm{G}$ & $3 \mathrm{fi}$ & $5 \mathrm{fi}$ & 0 \\
\hline morango & $\mathrm{H}$ & 1 exuvia, $4 \mathrm{fi}$ & $5 \mathrm{fi}$ & 1 inseto, 1 larva \\
\hline morango & D & $4 \mathrm{fi}$ & $9 \mathrm{fi}$ & l ovo, $1 \mathrm{fi}$ \\
\hline pêssego & $\mathrm{G}$ & 0 & $4 \mathrm{fi}$ & $5 \mathrm{fi}$ \\
\hline pêssego & D & $5 \mathrm{fi}$ & 0 & 0 \\
\hline uva & $\mathrm{C}$ & 1 inseto & 0 & 0 \\
\hline uva & $\mathrm{E}$ & 0 & 0 & $5 \mathrm{fi}$ \\
\hline uva & $\mathrm{B}$ & 0 & l exuvia & 0 \\
\hline uva & $\mathrm{G}$ & $6 \mathrm{fi}$ & $10 \mathrm{fi}, 1$ ácaro & 0 \\
\hline uva & $\mathrm{H}$ & 0 & $\begin{array}{c}1 \text { larva, } 4 \text { ovos, } 9 \mathrm{fi}, \\
1 \text { ácaro }\end{array}$ & $\begin{array}{c}1 \text { inseto, } 2 \text { larvas, } \\
2 \text { exuvias, } 7 \mathrm{fi}, 1 \text { ácaro }\end{array}$ \\
\hline uva & $\mathrm{D}$ & 0 & 0 & 0 \\
\hline
\end{tabular}


Tabela 8-A. Resultados individuais das análises de determinação de matérias estranhas em doces de frutas em pasta. São Paulo, 1998/99.

\begin{tabular}{|c|c|c|c|c|}
\hline \multirow{3}{*}{$\begin{array}{l}\text { Tipos de doces de } \\
\text { frutas em pasta }\end{array}$} & \multirow[t]{3}{*}{ Marcas } & \multicolumn{3}{|c|}{ Matérias estranhas } \\
\hline & & Números/tipos & Números/tipos & Números/tipos \\
\hline & & $\mathrm{l}^{2}$ colheita & $2^{\mathrm{a}}$ colheita & $3^{3}$ colheita \\
\hline Bananada & $\mathrm{E}$ & 1 ácaro & 0 & 0 \\
\hline Bananada & $\mathbf{J}$ & 0 & 0 & 0 \\
\hline Goiabada & $\mathbf{L}$ & 1 exuvia, 1 ovo, 2 fi & 0 & 1 ovo \\
\hline Goiabada & $\mathbf{M}$ & 1 exúvia & 1 larva & 0 \\
\hline Goiabada & $\mathrm{N}$ & 0 & $4 \mathrm{fi}$ & 4 fi, 1 ácaro \\
\hline Goiabada & $\mathbf{C}$ & $1 \mathrm{fi}, 1$ ácaro & $7 \mathrm{fi}$ & 0 \\
\hline Goiabada & $\bar{E}$ & 1 pêlo roedor & $3 \mathrm{fi}$ & $9 \mathrm{fi}$ \\
\hline Goiabada & $\mathbf{J}$ & $\begin{array}{c}2 \text { exúvias, } 1 \text { ovo, } 5 \text { fi, } \\
1 \text { ácaro }\end{array}$ & lovo, $6 \mathrm{fi}$ & 4 fi, 1 larva, 1 ovo \\
\hline Goiabada & 0 & $4 \mathrm{fi}$ & lovo, $5 \mathrm{fi}, 1$ ácaro & 0 \\
\hline Goiabada & $\mathbf{P}$ & 1 exuvia, 1 fi, 1 ácaro & lovo, $2 \mathrm{fi}, \mathrm{l}$ ácaro & 1 inseto, 1 ovo, $2 \mathrm{fi}$ \\
\hline Goiabada & $Q$ & 2 larvas, $3 \mathrm{fi}$ & $3 \mathrm{fi}, 1$ ácaro & $2 \mathrm{fi}$ \\
\hline Goiabada & $\mathrm{R}$ & 1 larva, 1 ovo, $5 \mathrm{fi}$ & 1 exuvia, $11 \mathrm{fi}$ & $2 \mathrm{fi}$ \\
\hline Goiabada & $\mathrm{S}$ & 0 & $5 \mathrm{fi}$ & 0 \\
\hline Goiabada & D & 0 & 1 fi, 1 ácaro & 0 \\
\hline Marmelada & $\mathbf{L}$ & 1 exuvia, $7 \mathrm{fi}$ & 1 ácaro & 0 \\
\hline Marmelada & $\mathrm{C}$ & 0 & 0 & 0 \\
\hline Marmelada & $E$ & 0 & 0 & $3 \mathrm{fi}$ \\
\hline Marmelada & $\mathrm{S}$ & 0 & 0 & 0 \\
\hline Marmelada & $\mathrm{D}$ & 0 & 0 & 0 \\
\hline
\end{tabular}

Os valores representam a média dos resultados das duplicatas.

$\mathrm{fi}=$ fragmento de inseto 
Tabela 9-A. Resultados individuais das análises de determinação de matérias estranhas em frutas em calda. São Paulo, 1998/99.

\begin{tabular}{|c|c|c|c|c|}
\hline \multirow{3}{*}{$\begin{array}{c}\text { Tipos de } \\
\text { frutas em calda }\end{array}$} & \multirow[t]{3}{*}{ Marcas } & \multicolumn{3}{|c|}{ Matérias estranhas } \\
\hline & & Números/tipos & Números/tipos & Números/tipos \\
\hline & & $1^{\mathrm{a}}$ colheita & $2^{2}$ colheita & $3^{a}$ colheita \\
\hline abacaxi & $\mathrm{L}$ & 0 & 0 & 0 \\
\hline abacaxi & $\mathrm{C}$ & 0 & 0 & 0 \\
\hline abacaxi & $T$ & 0 & 0 & 0 \\
\hline abacaxi & $E$ & 0 & 0 & 0 \\
\hline abacaxi & $\mathrm{U}$ & 0 & 0 & 0 \\
\hline abacaxi & $\mathrm{V}$ & 0 & 0 & 0 \\
\hline abacaxi & $\mathrm{D}$ & 0 & 0 & 0 \\
\hline ameixa & $\mathbf{L}$ & 1 larva & 0 & $\begin{array}{c}1 \text { inseto, } 12 \text { larvas, } \\
2 \text { ovos, } 2 \text { fi, } 226 \text { ácaros }\end{array}$ \\
\hline ameixa & $\mathrm{X}$ & 1 inseto, 1 larva & 1 larva & 0 \\
\hline ameixa & $\mathrm{C}$ & 0 & 0 & 0 \\
\hline ameixa & $\mathrm{P}$ & 1 inseto & 1 inseto & 0 \\
\hline ameixa & $\mathbf{S}$ & 0 & $\begin{array}{c}2 \text { exuvias, } 2 \text { ovos, } 7 \mathrm{fi} \text {, } \\
60 \text { ácaros }\end{array}$ & 9 ácaros \\
\hline ameixa & $\bar{Z}$ & $\begin{array}{c}1 \text { inseto, } 4 \text { larvas, } 13 \mathrm{fi}, \\
90 \text { ácaros }\end{array}$ & $\begin{array}{c}1 \text { inseto, } 1 \text { larva, } \\
29 \text { ácaros }\end{array}$ & $\begin{array}{c}2 \text { larvas, } 1 \text { exuvia, } \\
6 \text { ácaros }\end{array}$ \\
\hline ameixa & $\mathrm{D}$ & 1 larva, 6 fi, 5 ácaros & $\begin{array}{l}3 \text { larvas, } 3 \mathrm{fi}, \\
1 \text { pêlo roedor }\end{array}$ & l larva, l ovo \\
\hline figo & $\mathrm{L}$ & 0 & 1 ovo & 0 \\
\hline figo & $\mathrm{N}$ & 1 ácaro & 0 & 0 \\
\hline figo & $\mathrm{C}$ & $\begin{array}{l}26 \text { insetos, } 7 \text { fi, } \\
1 \text { pêlo roedor }\end{array}$ & 4 insetos & 1 inseto, 1 exuvia \\
\hline figo & $\mathrm{E}$ & 2 insetos & 0 & 1 inseto, 1 exuvia \\
\hline figo & $\mathbf{P}$ & 0 & 0 & 13 insetos \\
\hline figo & $\bar{Q}$ & 19 insetos & 9 insetos & $\begin{array}{c}39 \text { insetos, } 1 \text { larva, } \\
1 \text { exuvia }\end{array}$ \\
\hline figo & $\mathrm{D}$ & 0 & 109 insetos, $10 \mathrm{fi}$ & 32 insetos, 4 fi, 1 ovo \\
\hline goiaba & $\mathrm{L}$ & 1 larva & 1 inseto, 1 larva & 1 inseto \\
\hline goiaba & $\mathrm{N}$ & 4 insetos & 0 & 0 \\
\hline goiaba & $\mathrm{C}$ & 0 & 0 & 0 \\
\hline goiaba & $\underline{S}$ & 0 & 0 & 0 \\
\hline pêssego & $\mathbf{L}$ & 0 & 0 & 0 \\
\hline pêssego & $\bar{M}$ & 0 & 0 & 0 \\
\hline pêssego & $\mathrm{C}$ & 0 & 0 & 0 \\
\hline pêssego & $\mathrm{E}$ & 0 & 0 & 0 \\
\hline pêssego & W & 0 & 0 & 0 \\
\hline pêssego & $\mathrm{K}$ & 1 pêlo de roedor & 0 & 0 \\
\hline pêssego & $\mathrm{Y}$ & 0 & 0 & 0 \\
\hline pêssego & $\mathbf{P}$ & 0 & 0 & 0 \\
\hline pêssego & D & 0 & 1 larva & 1 ácaro \\
\hline salada de fiutas & $\mathrm{L}$ & 0 & 0 & 1 ácaro \\
\hline salada de frutas & $\mathrm{C}$ & 0 & 0 & 20 ácaros \\
\hline salada de frutas & $\mathrm{E}$ & 0 & 0 & 0 \\
\hline salada de frutas & $\mathrm{K}$ & 0 & 0 & 0 \\
\hline
\end{tabular}

Os valores representam a média dos resultados das duplicatas

$\mathrm{fi}=$ fragmento de inseto 